University of Rhode Island

DigitalCommons@URI

Open Access Dissertations

2020

\title{
FEMALE COMIC GROTESQUE CHARACTERS IN VICTORIAN \\ NOVELS: INVESTIGATING THE POSSIBILITIES OF LIMINALITY
}

Barbara A. Farnworth

University of Rhode Island, bafarnworth@gmail.com

Follow this and additional works at: https://digitalcommons.uri.edu/oa_diss

\section{Recommended Citation}

Farnworth, Barbara A., "FEMALE COMIC GROTESQUE CHARACTERS IN VICTORIAN NOVELS:

INVESTIGATING THE POSSIBILITIES OF LIMINALITY" (2020). Open Access Dissertations. Paper 1142.

https://digitalcommons.uri.edu/oa_diss/1142

This Dissertation is brought to you for free and open access by DigitalCommons@URI. It has been accepted for inclusion in Open Access Dissertations by an authorized administrator of DigitalCommons@URI. For more information, please contact digitalcommons@etal.uri.edu. 
FEMALE COMIC GROTESQUE CHARACTERS IN VICTORIAN

NOVELS: INVESTIGATING THE POSSIBILITIES OF LIMINALITY

BY

BARBARA A. FARNWORTH

A DISSERTATION SUBMITTED IN PARTIAL FULFILLMENT OF THE

REQUIREMENTS FOR THE DEGREE OF

DOCTOR OF PHILOSOPHY

IN

ENGLISH

UNIVERSITY OF RHODE ISLAND

2020 
DOCTOR OF PHILOSOPHY DISSERTATION

\author{
OF
}

BARBARA A. FARNWORTH

\title{
APPROVED:
}

Dissertation Committee:

Major Professor:

Carolyn Betensky

David Faflik

Patricia Morokoff

Nassar H. Zawia

Dean of the Graduate School 


\begin{abstract}
Female comic authors during the nineteenth century have received little attention from twentieth and twenty-first century literary critics. As Regina Barreca observes, major studies of the role of comedy in British literature do not deal with women writers (Barrecca 1988 11). Several anthologies which focus on humor in nineteenth-century literature begin with Jane Austen and then ignore every other female comedic writer. Similarly, studies of the comic grotesque in nineteenth century literature focus primarily on how it is employed by male authors such as Charles Dickens, William Thackeray and Anthony Trollope. My dissertation will address this imbalance by examining the employment of the female comic grotesque in humorous novels by three non-canonical, female authors, Emily Eden, Catherine Gore and Frances Trollope.

Humorous texts often challenge oppressive ideas and socio-cultural norms through the use of satirical wit. Nineteenth-century female authors employ humor to disguise their attacks on contemporary values and thus avoid retribution. One comedic method they utilize is inversion which involves an unexpected and humorous switching of normal roles so that, for example, the master obeys his servant and wife rules her husband. Through these reversals of normal roles, the rules and prohibitions of culture are suspended so that readers can view their social and political relationships with more clarity; inversions may, therefore, act subversively by demonstrating possibilities for a different societal structure. These comic inversions are very often located in comic grotesque characters. In this dissertation, I analyze
\end{abstract}


female comic grotesque characters in female-authored novels that challenge upperclass and male authorities by inverting class and gender hierarchies. In these humorous novels, overweight female characters, grotesque by virtue of their body size, rise from their middle-class origins to achieve upper class status. Similarly, loquacious grotesque women challenge gender role norms by ruling over their husbands and male relatives. 


\section{ACKNOWLEDGEMENTS}

I wish to express my deepest gratitude to my advisor, Professor Carolyn Betensky, for her generous support, advice, and guidance throughout my doctoral process. Her confidence in my project has been essential to my success. Thank you also to my dissertation committee members Professors David Faflik, Patricia Morokoff, J. Jennifer Jones and Rachel Dicioccio for their feedback, enthusiasm, and advice. Additional thanks to Director of Graduate Studies Professor Kathleen Davis and to Graduate Program Administrator Michelle Caraccia, who has proved invaluable in helping me navigate the administrative process.

Special thanks to my husband, Michael Raciti, and daughter, Christina Raciti, for their encouragement, patience and loving support. Many thanks to my mom, Ida Farnworth, who inspired me with her love for and commitment to higher education. 


\section{TABLE OF CONTENTS}

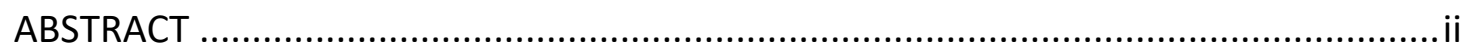

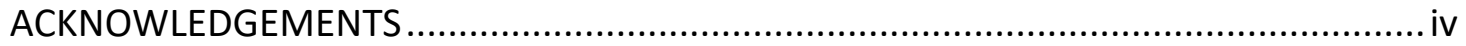

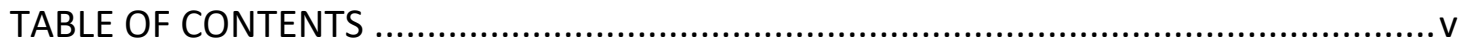

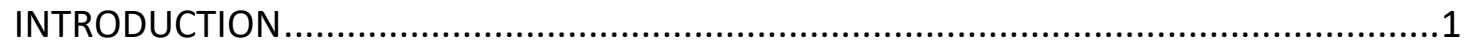

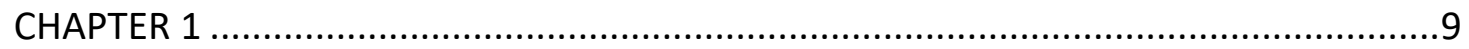

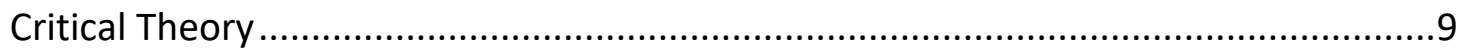

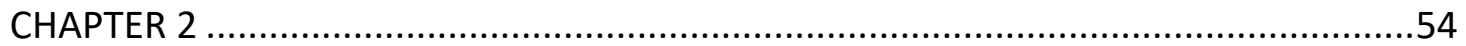

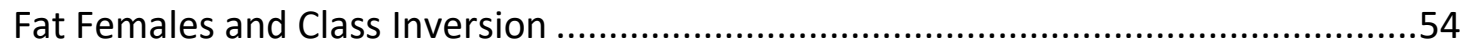

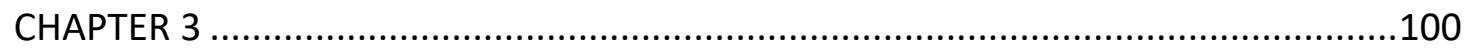

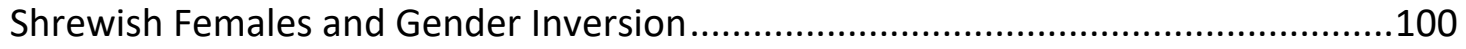

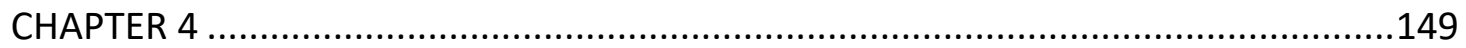

Comic Grotesque as Picaresque Heroine.........................................................149

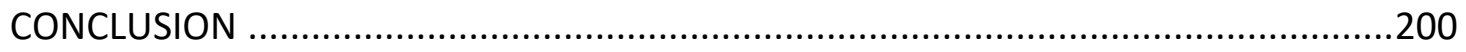

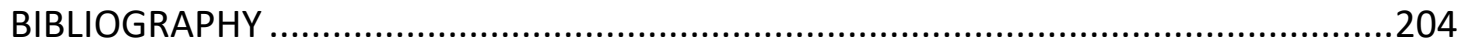




\section{INTRODUCTION}

A major shift in comic sensibility occurred in eighteenth-century Britain. The primarily intellectual appeal of traditional comic theory, which was based on superiority and ethical correction, gradually yielded to a comedy of incongruity, which may invoke affection as well as laughter. Stuart Tave coined the term "amiable humorist" in his study which speculates that during the late-eighteenth century a good-natured and good-humored ideal arose in British culture (ix). This ideal encouraged sympathetic laughter and discouraged the punitive laughter, ridicule, and satiric wit of early eras (44). Similarly, Robert Martin highlights nineteenthcentury discomfort with humor through his analysis of the debates surrounding the appropriate types of comedy and the variety of definitions of satire and wit (31). Martin also identifies an eventual shift from genial laughter to a greater focus on wit, associated with intelligence and satire, in the 1860's and 70's (29). Both theorists identify the mid-nineteenth century as the high point of the move from satire to amiable humor.

Yet despite the apparent discomfort among the Victorians with wit and satire, such humor does not totally disappear in the first half of the nineteenth century. For example, Charles Dickens publishes Pickwick Papers in 1836, the satirical periodical Punch begins in 1841, and Thackeray's satirical works Vanity Fair and The Snobs of England appear in 1847 and 1848, respectively. What does seem clear, however, is that examples of such humor all came from the pens of male writers (Punch was created, written and illustrated by an all-male staff). 
The apparent elimination of wit and satire from texts by women would seem to make sense because, although the prevalent discomfort with this humor applied to all texts, female wit was considered especially threatening. Conduct books warned that a man with good sense would avoid marrying a witty female, who was seen as a potential satirist. Moreover, a woman engaging in group laughter presented the appearance of knowing more than she should. Further, wit was (and often still is) coded as masculine and cynical; nineteenth-century women were typically thought to be too pure and saint-like to understand this humor. Modern literary critics analyzing humor in the nineteenth century confirm this attitude. Book-length analyses of humorous authors commonly begin with Jane Austen and then continue with an all-male list. It would appear that even contemporary critics maintain a preconception as to the presence or permissibility of wit in women. Thus, there seems not only to be general discomfort with witty laughter among nineteenthcentury Britons but, further, a more specific disapproval, in the nineteenth century and perhaps in the centuries since, of female witty laughter.

As I have elaborated above, male authors persisted in writing texts with satirical humor, despite the general discomfort associated with it. This raises an obvious question: what happened to female authors of comedy during this same time period? Austen and her texts are celebrated for their humor, but who are her female successors? From the time of Austen's death in 1817 until the 1860's and 1870's when popular, sensation authors such as Mary Elizabeth Braddon and Rhoda Broughton targeted social issues through satire, where did women express their wit? 
This time period certainly did produce respected female authors, such as Charlotte Brontë and Elizabeth Gaskell. Eileeen Gillooly has identified and analyzed their texts for feminine humor, a subtle satirical wit critiquing political and social mores, but these authors are not primarily identified as humorists either by their contemporaries or by modern readers.

Female comic authors during the mid-nineteenth century have received little attention from twentieth and twenty-first century literary critics. As Regina Barreca observes, major studies of the role of comedy in British literature do not deal with women writers (11). Anthologies of nineteenth-century humorous literature support her argument as they typically begin with Jane Austen and then ignore every other female comedic writer. Further, Nancy Walker points out that women's humor "has been largely omitted from the official canon ... been allowed to go out of print, to disappear from all but the dusty reaches of library shelves" (120). Indeed, a survey of non-canonical work of the 1820 's through the 1850 's reveals several witty female authors whose work was quite popular among contemporary audiences but has lapsed into relative obscurity in modern times.

My dissertation studies representations of satirical wit from non-canonical and/or lesser-known authors such as Emily Eden, Catherine Gore, and Frances Trollope in order to recognize their contribution to nineteenth century literature. Although these authors were contemporaries of Austen, all born in the late eighteenth century, they published later in the period, from the 1820's through 1850 's. All three authors were great admirers of Austen's novels and, in fact, both 
contemporary and modern readers often refer to the humor in their texts as examples of Austenian wit.

Catherine Gore was a prolific writer of comedic novels and plays from the 1820's through 1850's. I focus on her 1831 novel, Pin Money, which in her preface Gore described as an attempt to "transfer the familiar narrative of Miss Austen to a higher sphere of society" (Kendra Para. 1). Emily Eden, more well-known for her published letters from India, wrote two humorous novels, The Semi-Attached Couple in 1839, and The Semi-Detached House in 1859. Frances Trollope, who has received some attention from modern scholars, wrote satirical travelogues and novels; her humorous works are an important representation of female wit in the early- to midnineteenth century. I concentrate on her Widow Barnaby trilogy written from 1839 to 1843.

My analysis of these humorous novels reveals the deployment of comic grotesque characters to challenge the social order by inverting gender roles and class status. Through inversion, the grotesque female figure in Victorian texts enters a liminal space, a realm of pure possibility where new combinations of cultural givens can be playfully explored. In this space, the female grotesque can subvert authority and challenge socio-cultural norms. Although this figure may, in challenging upperclass and male authority, convey deeply rebellious and subversive behavior, the texts themselves are not rebellious or subversive toward cultural norms. Therefore, the female author is able to disguise her attacks on contemporary values and thus avoid damage to her reputation. The female comic grotesque character becomes a way for 
nineteenth-century female authors to experiment with potential freedoms, especially in gender and class roles. Gender and class roles are particularly important during this time; Davidoff and Hall designate the end of the eighteenth century as a significant period because of the strengthening of the middle class and its differentiation from the aristocracy and lower classes. In addition, a "realigned gender order emerged" with new expectations surrounding the proper roles for men and women (xvi).

Chapter One concentrates on the scholarship about the aesthetic grotesque; an analysis of Mikhail Bakhtin's theory of carnival and the comic grotesque; the female grotesque; inversions; and the liminal space created by the grotesque and its hierarchical inversions. The grotesque can be defined as an ambivalent, ambiguous mix of disparate elements, which usually includes a comic aspect, often referred to as ludicrousness. This is frequently combined with a fearful aspect, such as disgust or even terror. The combination of these disparate elements can create unresolved conflicts in intellectual and/or emotional responses to the grotesque object or individual. The grotesque produces a paradoxical and/or uncomfortable reaction in the viewer or reader; laughter from the comic grotesque, for example, may be tinged with embarrassment.

In Rabelais and his World, Mikhail Bakhtin theorizes that the grotesque body is the most important comic element of carnival and carnivalesque literature. He focuses on the comic, rather than the fearful, aspect of the grotesque and on its liberating nature. According to Bakhtin, laughter unveils the truth about the world and power 
and it exposes the supposed naturalness of the social order as artificial. The grotesque body focuses on the material body - the lower stratum involved in eating, drinking, defecating and copulating. Bakhtin also theorizes that carnival's comic grotesque body participates in temporary inversions of class hierarchies so that the entire official, hierarchical system is suspended. Therefore, lower status individuals relate to higher status individuals as equals and even temporarily assume authoritative roles. These hierarchical inversions, part of what Bakhtin refers to as a time of play and freedom, reveal the possibility for different societal and political structures. Anthropologist Barbara Babcock defines inversion as an "act of expressive behavior which inverts, contradicts, abrogates or in some fashion presents an alternative to commonly held cultural codes, values and norms" (14). Further, psychologist Erik Ericson suggests that inversions, by allowing us to engage in "reversible operations," create "Spielraum," a space in which one can take chances with new roles and ideas (Babcock 25). Class and gender inversions in these texts, therefore, create liminality and allow for the exploration of new social and cultural possibilities in the novel and, perhaps, in the world outside the novel.

According to anthropologist Victor Turner, liminal spaces exist on the edge of normal activities and, like the grotesque, are marked by contradiction and ambiguity. Turner conceived of liminality as a state "betwixt and between" the normal, day-today cultural and social states and he described it as a "time of enchantment when anything might happen" (1979 465). Because liminal states allow society to comment on and critique itself, liminality can, but does not inevitably, have a 
subversive character. The unresolved conflict of disparate elements and the hierarchical inversions found in the grotesque suggest that the grotesque is a liminal state. The grotesque characters in the novels I study allow the reader to recognize and explore the cultural assumptions at work in the nineteenth century and to explore the possibilities of new roles and cultural ideas.

In the next three chapters, I analyze the deployment of comic grotesque female characters and their potential for subversiveness. Chapter Two examines overweight female characters as representatives of the comic grotesque. I contrast the comic grotesque characters of Mrs. Musgrove in Jane Austen's Persuasion with Mrs. Hopkinson in Emily Eden's The Semi-Detached House. Chapter Three investigates three excessively talkative grotesque women and their gender inversions in Eden's The Semi-Attached Couple and Catherine Gore's Pin Money. In both novels, the grotesque women shrewishly rule over their husbands and/or male relatives. Chapter Four analyzes both class and gender inversions performed by the picaresque main character of Frances Trollope's Widow Barnaby trilogy. In the texts I discuss in Chapters Two and Three, the female comic grotesque characters are secondary characters. The effect of their gender/class inversions and their liminality, therefore, remains subtle because of their relatively minor roles in the novels. In Frances Trollope's Widow Barnaby trilogy, however, the comic grotesque character, Martha Barnaby, is the main character of the series and the effect of these inversions and liminality is greater. 
The works of Eden, Gore and Trollope clearly demonstrate that female authors of comedy did not disappear from the time of Austen's death until the sensation authors of the 1860's and 1870's. In fact, although comedic authors of the midnineteenth century have been omitted from the canon, their novels were extremely popular with their contemporaries. In addition, they, like Austen, Braddon and Broughton, targeted social issues, such as rigid class and gender roles, through their wit and satire. By focusing on these authors and their novels, my dissertation addresses a gap in the critical work on nineteenth-century female humor. 


\section{CHAPTER 1}

\section{Critical Theory}

In this chapter, I concentrate on examining the theories surrounding the grotesque with a focus on the comic grotesque. First, I explore general definitions of the term as used in art and literature with a focus on the characteristics of the grotesque. Next, I analyze Mikhail Bakhtin's theory of the carnival and comic grotesque through his text Rabelais and his World. Then, I turn to feminist critiques of Bakhtin's work as well as feminist interpretations of the female grotesque as subversive. The last sections of this chapter examine inversions of gender and class hierarchies as they reverse social and cultural norms and the relationship of carnival, the grotesque, and inversion to liminal spaces.

\section{The Grotesque: An Aesthetic Term}

The grotesque is commonly used as an adjective for objects or persons that are ugly, strange or disgusting. The aesthetic term, however, as applied to art and literature, has a much more complex meaning. Most theorists of the grotesque, such as Geoffrey Harpham (1976) and Philip Thomson (1972), stress the difficulty of defining the term. Harpham, for example, refers to the grotesque as a slippery concept and argues that the definition can't depend solely on formal properties because the perception of the grotesque is never fixed or stable, but always a process (14). Frances Barasch points to the lack of agreement among scholars in their usage of the term and concept. She reflects this uncertainty by couching her definition in subjective terms: "it would seem that artists and writers of any era 
invariably produced forms which in respect to the conventional ideas of their worlds, were irrational and grotesque" (1971 164).

Most theorists begin their definition of the grotesque with an explication of the etymology of the term, which comes from underground (cave-like) artwork on Roman ruins excavated in the late fifteenth century. This artwork consisted of a confusion of heterogeneous elements with an interweaving of animal, human, plant, and architectural elements (Thomson 12). These images include beasts fused with animal bodies and birdlike wings, human forms fused with leaflike patterns weaving plant life, masklike human heads and various mythological figures including centaurs, fauns, and satyrs. Many Renaissance art critics described the grotesque style as monstrous, irrational, indecorous, or immoral. All of them found it disquieting (Henning 108-9). Some art experts, however, supported this grotesque art form finding it a powerful expression of art so that several Italian artists of the fifteen and sixteenth centuries employed this style in their paintings. As a result, the grotesque became a well-known motif in the religious and secular art of the Renaissance. Initially, the term grotesque was used only for paintings and murals; later, it was extended to literature in France during the sixteenth century and then in Germany and England in the eighteenth century. ${ }^{1}$

Although scholars of the grotesque have produced a variety of definitions and interpretations, most theorists agree that grotesque art and literature incorporate four basic characteristics: the grotesque contains a mix of heterogeneous elements;

1 Frances Barasch has an excellent history of the scholars of the grotesque from Vitruvius through the nineteenth century. 
this ambivalence created by these disparate elements creates a conflict which cannot be resolved; the reader and/or viewer's reaction to the grotesque is complex and ambivalent; and the cultural context determines the grotesqueness of an object or person.

The majority of scholars agree that the grotesque is an ambivalent, ambiguous mix of heterogeneous or disparate elements. Philip Thomson describes it as a violent clash of opposites and defines the grotesque as "ambivalently abnormal" (28). In his study of the grotesque in Charles Dickens' novels, Michael Hollington calls grotesque art an "essentially mixed or hybrid form" with heterogeneous elements combining in unstable, conflicting, paradoxical relationships (1). These combinations include: human forms mixed with animal forms; the natural with the supernatural; and the comic with the monstrous and misshapen (1). Similarly, Kathryn Hume theorizes that the grotesque arises from tensions when two opposed value clusters meet. In her theory the first set of values consists of "law, form, order, rationality, the classical body, the ideal, consciousness, meaning, state beliefs, and decorum" (79). The second set of values (as opposed to first set) includes formlessness, death, fragmentation, chaos, multiplicity, the unorganizable, the lower body, the unconscious, and the female body. The grotesque occurs when elements from each set of values interact. Hume's model reflects Bakhtin's theory, which I will explore later in this chapter, as Bakhtin contrasts the lower body against the upper (or classical) body and "lower-class life-energies" against upper-class constraints (Hume 80). 
Many theorists² follow John Ruskin's theory of the grotesque, in his “Grotesque Renaissance" in The Stones of Venice, as a combination of a playful or comic aspect, also referred to as ludicrousness, with a fearful aspect, such as disgust or even terror. For Ruskin, grotesque art is the product of a strong urge to play, invent, and manipulate. He also, however, stresses the combination of and interaction between intellectual play and terror. According to Ruskin, the fearful or terrible aspect of the grotesque is associated with horror, anger, or awe at the human condition in grotesque. Therefore, the grotesque can be playful but still contain fearfulness; it can also be fearful but never completely exclude "all idea of jest" (138). Karl Ruthke, following Ruskin, states that it involves "ludicrous horror or horrifying ludicrousness" such that an object, person or situation appears at once frightening and funny (73). ${ }^{3}$

Several theorists suggest that the fusion of these disparate or heterogeneous elements is impossible. Philip Thomson, for example, calls the grotesque an unresolved conflict of qualities. According to Harpham, the ultimate paradox of the grotesque is that a body, object, or event is no longer grotesque if this conflict of elements is resolved (76). The grotesque not only creates a conflict of between fearful and comic aspects, it also tends to conflict with the world as defined by our cultural norms by violating some aspect of our religious, moral, social, or natural world. For Harpham the grotesque body can create an existential crisis as it calls

\footnotetext{
${ }^{2}$ These theorists include: Barasch 1971, Clayborough 1965, Harpham 1982, Henning 1981, McElroy 1989, Hollington 1984, Steig 1970, Thomson 1972.

${ }^{3}$ Although the majority of theorists define the grotesque as including both fear and ludicrousness, they differ in their emphasis on one quality over the other. Wolfgang Kayser, for example, focuses on the fearful aspect while Bakhtin concentrates on the ludicrous or comic aspect. Kayser views the ambivalence as threatening; therefore, he tries to resolve the tension and limits grotesque to a source of terror and destruction. On the other hand, Bakhtin sees it as ultimately joyous and regenerative.
} 
"into question the adequacy of our ways of organizing the world, of dividing the continuum of experience into knowable parts" (1982 3).

According to Sylvie Henning the grotesque manifests its "tensions and ambiguity" only by maintaining both the fearsome and ludicrous aspects (112). She criticizes theorists of the grotesque who try to lessen the ambiguity in grotesque. Henning argues for an understanding of the grotesque that maintains its full complexity and its ability to "unsettle and disturb" (108). Kathryn Hume agrees with Henning's argument stating that "the fusion or reconciliation of these disparate elements is impossible (85).

An important element of the grotesque is the focus on the reader's or viewer's reaction to a work of art or literature or character in the text, especially on their emotional, as opposed to their intellectual, experience of the grotesque. Phillip Thomson, for example, argues that the grotesque produces a powerful, mixed emotional reaction in the viewer/reader; he views this reaction as one of horror (or disgust or anger) and amusement at the same time. Similarly, Kathryn Hume theorizes that the grotesque produces a "visceral frisson of discomfort" in readers (78). This discomfort, she argues, arises from their contradictory and irreconcilable reactions: "horror and laughter, terror and play, rejection and sadistic glee, repulsion and identification" (83). The more we are repelled by what we are forced to contemplate, argues Hume, the more uncomfortable we find our impulse to laugh or to enjoy the forbidden. 
Finally, the grotesque can create a paradox of attraction and repulsion (Thomson 1972, Cohen 1996). Contemporary theorists who emphasize the impossibility of providing a univocal definition of grotesque agree with its affinity to a paradox. Thomson argues that "the paradox of attraction/repulsion" is basic to the grotesque and the mix of incompatibles remains unresolved (51). Isabelle Hervouet-Farrar analyzes viewer reactions to the Renaissance grotesque which, as I explained above, is characterized by human-animal-vegetable-architectural hybrids. According to Hervouet-Farrar the viewer, faced with such hybrids, is "arrested between the possibility that it makes no sense and the idea that it means something he/she does not understand" (3). This "state of indecision," she surmises, is the "grotesque experience" (3).

An additional quality of the grotesque object or person is how it can disrupt our ordinary perception of the world. According to Wolfgang Kayser, the familiar world is suddenly rendered strange through strategies of the grotesque such as reversal, mingling, and distortion. Further, the mix of the ludicrous and monstrous causes a hesitation in both the characters' and readers' perceptions of events. Our familiar perception of reality is disturbed through excess, exaggeration, and hyperbolism. Geoffrey Harpham presents a positive view of this disturbance in our perception, stating "confused things lead the mind to new inventions and lie at the heart of all scientific discoveries of a revolutionary character" (1982 17). As I discuss below, the notion of play is closely related to both the grotesque and the liminal. 
The grotesque characters I study in my dissertation produce a mix of emotions in the reader as well as in other characters in the novel. Because they are comic grotesque characters, the predominant reaction to them tends toward amusement, although disgust is a factor as well. For example, in Chapter Two I study Mrs. Hopkinson, a grotesque character in The Semi-Detached House, whose immense fatness is seen by herself and by the other characters as both repulsive and amusing. Similarly, the excessively talkative Mrs. Douglas in The Semi-Attached Couple, one of the subjects of Chapter Three, provokes both laughter and derision for her shrewish and cynical nature. The reader's potential disapproval of her criticisms is mitigated by her accuracy. The grotesque characters in my study do not, however, tend to provoke strong negative emotions such as horror or terror, the category of grotesque studied by Wolfgang Kayser. Because of this focus on amusement, I analyze them in terms of comic grotesque theorists relying most heavily on Bakhtin's theories (see below).

\section{Bakhtin's Theory of Carnival and Comic Grotesque}

Mikhail Bakhtin and Wolfgang Kayser are the most influential modern theorists of the grotesque as all later twentieth and twenty-first century theorists of the grotesque engage with and build on their arguments. Although Kayser and Bakhtin both agree that the grotesque is a mixture of the horror and the comic, they reach opposite conclusions in their representations of the prominence of each aspect. Kayser emphasizes the terror in the grotesque while minimizing the comic elements which may be present. Kayser and the theorists who have followed and built upon his 
work argue that the grotesque has a close relationship to the psychoanalytic, especially to the uncanny. Bakhtin's study, on the other hand, focuses on the comic aspect of the grotesque and on its life-affirming, joyous and liberating nature. For Bakhtin, the grotesque's primary quality is not fear but rather its ability to transform the terrifying aspects of life into comic monsters. Because my dissertation focuses on the comic grotesque and because Bakhtin's theory of the comic grotesque is foundational, in the following pages I examine his theory in detail.

Bakhtin's work on the grotesque, Rabelais and his World, is part of his theory of carnival as articulated in his study of Francois Rabelais' work. Strictly speaking, "carnival" refers to the period of feasting and revelry just before Lent, including Mardi Gras in France, Fastnacht in Germany and Shrove Tide in England. In Bakhtin's work, however, carnival includes not only specific festivals and feast days celebrated throughout the year but also the range of popular, festive practices developed during the Middle Ages (217-8). Bakhtin estimates that carnivalesque celebrations represented a considerable part of the life of medieval men, including the amount of time involved in them. Large medieval cities, for example, devoted an average of three months per year to theses festivities.

Bakhtin locates these practices within a Middle Ages' cultural binary organized around a serious, official stratum and a laughing, unofficial stratum. Bakhtin argues that the culture of the Middle Ages consisted of an official, serious side, related to the power and the imagery of the Church, and an unofficial side, linked to the practices of carnival and its popular festive imagery. Carnivalesque imagery offered 
an alternative to official imagery, but by suspending and/or inverting social hierarchies, carnival also provided an alternative construction of social relations. Through carnival, Bakhtin argues, the people acquire a second life so that, for a time, they enter "the utopian realm of community, freedom, equality and abundance" (9). The grotesque, therefore, is located in this utopian realm--the "festive, democratic, popular culture of the Middle Ages" (9). Bakhtin characterizes carnival as a world where freedom is absolute--all hierarchical barriers of everyday existence are suspended (188). Carnival is also a mode of thinking, a "living attitude to the world" (Smedley 82). Carnival is chiefly characterized by parodic unmasking, playfulness, ambivalent laughter, grotesque realism, use of materialized bodily imagery and the ritualistic inversion of conventions.

While Bakhtin lays out a chronology of carnival from the ancient world through the twentieth century, his main focus is on carnival in the Middle Ages and on the Renaissance and post-Renaissance transfer of carnival from the marketplace to literature. From the mid-seventeenth century onwards the carnival spirit found "expression solely in the realm of literature" and Bakhtin terms carnivalesque literature as grotesque realism (131). He argues that "realistic literature of the last three centuries is strewn with the fragments of grotesque realism, which...manifest a renewed vitality" (Bakhtin 34). In this literature, the carnival-grotesque form exercises the following functions: "to consecrate inventive freedom, permit combinations of a variety of different elements..., and to liberate the prevailing point of view of the world, from conventions and established truths, from clichés, from all 
that is humdrum and universally accepted" (34). This carnival spirit offers the chance to have a new outlook on the world, to realize the relative nature of all that exists, and to enter a completely new order of things.

Central elements of Bakhtin's theory of carnival and the grotesque include: laughter; the material body (or lower bodily stratum); and the inversion of hierarchies. I explore these elements of his theory because the novels in my analysis are comedic and their laughter is carnivalesque; the grotesqueness of the characters in these novels arises from the material body; and these grotesque characters bring about the inversion of gender and class hierarchies.

The Qualities of Carnivalesque Laughter

Laughter in the carnival, or festive folk laughter, is both liberating and healing. Bakhtin argues that festive folk laughter means the defeat of power, of earthly kings, of the earthly upper classes, of all that oppresses and restricts. A laughing response to grotesque images also exposes the supposed naturalness of the social order as artificial. Finally, laughter defeats fear. The grotesque renders the terrifying elements of life into a comic monster. In the carnivalesque, terror is transformed into something joyous and comic; the monsters are conquered by fear-dispelling laughter. For Bakhtin, the terror comes from outside sources such as authority figures or natural disasters and is defeated by the grotesque; thus, the grotesque itself is more comic than terrifying. Specifically, Bakhtin characterizes carnivalesque or festive laughter as embodying five qualities: universality; ambivalence; freedom; 
fearlessness or the victory of laughter over fear; and demystification ${ }^{4}$ accompanied by the defeat of power (90).

Festive laughter is universal in terms of its responsiveness to the gaiety of the entire occasion, rather than directed at a specific object or isolated comic event. This type of laughter doesn't represent the triumph of the individual but the victory of the "great generic body of the people" (88). The individual, in fact, is subsumed by the social in the processes of carnival. Laughter "embodies the social consciousness of all the people" (92). Bakhtin contrasts the gaiety of carnivalesque laughter with that of the modern satirist who feels superior to the object of mockery (12). Festive laughter is not egotistical or superior; it does not conform to the comic theory of superiority. Instead, it is inclusive, acknowledging that everyone is foolish, both those who mock and those were mocked. Carnival laughter "is directed at all and everyone, including the carnival's participants" (50). In a carnival performance, therefore, the laughter is directed at both the performers and the audience members. According to Bakhtin, festive laughter is loud, collective, and communal; it is expressed as an unrestrained belly-laugh rather than a haughty or superior smile.

The ambivalence in carnival laughter arises from its ability to be triumphant and affirmative while simultaneously mocking and deriding (Bakhtin 122-3). According to Emerson and Morson, carnival laughter is ambivalent in that it is neither "negative nor unidirectional and does not pass authoritative judgments;" instead it values "the

\footnotetext{
${ }^{4}$ In "Epic and the Novel," Bakhtin credits laughter with the ability to scrutinize objects up close and thus demystify it, i.e. "open its external shell, look into its center, doubt it, take it apart, dismember it, lay it bare and expose it, examine it freely and experiment with it" (23).
} 
unfinished in everything" (444). Stallybrass and White describe this laughter as both humiliating and mortifying but at the same time reviving and renewing (8).

According to Patricia Keith-Spiegel, ambivalent laughter generates simultaneous and incompatible emotions in an individual. Keith-Spiegel theorizes that Plato's dialogue Philebus, is the prototype of ambivalence theory. In this dialogue, Socrates taught Protarchus that laughter arises from a simultaneity of pleasure and pain resulting from envy and malice. The clashing emotions which resolve themselves through laughter include love modified by hate; mania alternating with depression; playful chaos mixed with seriousness. Significantly, this language closely aligns with the viewer's and reader's incompatible reactions to the grotesque. As I described above, reactions to the grotesque are often a mixture of horror or disgust and amusement.

Bakhtin states that laughter has an "indissoluble and essential relation to freedom" (89). Laughter embodied the freedom facilitated by the license of feast days. This celebration of permissiveness which took place during carnival contrasted significantly with the "strictures that governed the norms of everyday," that is official life (89). Bakhtin emphasizes, however, that the consciousness of freedom could "only be limited and utopian" (95). He views it as a mistake to believe that the popular love of laughter, as of another truth, could always reach full awareness, "expressing a critical and clearly defined opposition" to official life (95). Further, the "freedom granted by laughter" was constrained by the fear instilled in people by the power of official culture (95). As I will discuss below, the freedom generated by 
carnival laughter is limited by official power, suggesting that any potential subversiveness arising from laughter is temporary.

Laughter also brings about demystification and the defeat of power, of earthly kings, of the earthly upper classes, of all that oppresses and restricts (94). By exposing the supposed naturalness of the social order as artificial, laughter unveils the truth about the mystery of the world and power. This laughing truth degrades power. This defeat of power and demystification was brought about by carnival imagery, usually grotesque imagery, which held up "emblems of power and authority as objects of derision" (94). The laughing response to these images "permitted the expression of a...popular truth" exposing the supposed naturalness of the social order as artificial (94). In this way, laughter opens men's eyes on that which is new, turning them to the future as opposed to the oppressive authority of the past and the present.

In "Epic and the Novel," Bakhtin identifies a similar propensity in laughter where he credits it with the capacity to thoroughly scrutinize objects. Laughter, he theorizes, has the "remarkable power of making an object come up close, of drawing it into a zone of crude contact where one can finger it familiarly on all sides, turn it upside down, inside out, peer at it from above and below, break open its external shell, look into its center, doubt it, take it apart, dismember it, lay it bare and expose it, examine it freely and experiment with it" (23). This ability to scrutinize objects is related to laughter's ability to unveil mysteries surrounding power and to see the artificiality of the social order. 
Characters, such as the rogue, the clown and the fool perform central carnival roles, but are also employed in literature to condemn social mores. Bakhtin argues that the authors need these characters to "make strange the world of social conventionality" and to expose "all that is vulgar and falsely stereotyped in human relationships" (Bakhtin 1981 404). Therefore, these characters create ambivalent laughter - the laughter of carnival which is both festive and mocking. Although these comic characters are often ridiculed by a text's narrator, they can also serve as a mask to give voice to an author's criticisms of his/her society. This concept is quite important for my dissertation as I analyze the ability of comic grotesque characters to challenge both male and class authority.

Bakhtin's theory of laughter appears to credit the comic with subversive potential. As Christine Smedley states, "the use of laughter as narrative strategy to transcend the authoritarian world is well established" (3-4). Many comedy theorists have argued for laughter as a force of resistance, freedom, and the "rejection of official, authoritarian...discourse (Hohne, xvi). In his 1711 essay, "The Freedom of Wit and Humour," Lord Shaftesbury argues, "the natural free Spirits of ingenious Men, if imprison'd and controul'd, will find out other ways of Motion to relieve themselves in their Constraint: and whether it be in Burlesque, Mimickry or Buffoonery, they will be glad at any rate to vent themselves, and be reveng'd on their Constrainers." Sigmund Freud describes the ability of jokes to give vent to social criticism that might otherwise be repressed (113). Tendentious jokes, he continues, make "aggression or criticism possible against those in exalted positions who claim to exercise authority" 
(125). Therefore, jokes are a potent form of criticism as well as a covert style of rebellion (125). Joanne Gilbert argues for a strong relationship between humor and power by pointing out laughter's ability to empower the humorist by "restoring to oneself enough power and control to speak the unspeakable" (9). Mary Douglas argues that a joke is always potentially subversive because "it's form consists of a victorious tilting of uncontrol against control, it is an image of the levelling of hierarchy, the triumph... of unofficial values over official ones" (98). These theorists assert laughter's ability to criticize power and even to rebel against authority and carnival laughter with its demystifying function achieves the same goal. ${ }^{5}$

Women's Comedy as Inherently Subversive

Several prominent feminist theorists, closely associate women's comedy with aggression, arguing that women's humor is inherently subversive. This theory is essential to my analysis of the potential subversiveness of comic grotesque characters in humorous texts authored by women. In Three Guineas, for example, Virginia Woolf states, "the dominator" in our culture is "peculiarly susceptible...either to ridicule or defiance on the part of the female sex;" she advocates laughter as an antidote to dominance (qtd in Barreca 21). Hélène Cixous, in "The Laugh of the

\footnotetext{
${ }^{5}$ On the other hand, many comic theorists point to the more conservative functions of humor. Using the Aristotelian definition of comedy, Umberto Eco argues that comedy is necessarily restricted to reinforcing the status quo rather than a transgressive function. Although the comic is an instrument of social control, it "can never be a form of social criticism" (Taylor 53). Comedy in its representations of low life and lawlessness "performs a conservative function for they necessarily emphasize to us the very codes they violate" (Taylor 53). Stuart Tave also argues for the non-subversive nature of comedy in eighteenth and nineteenth century Britain. He identifies a major shift in comic sensibility during this time period from traditional comic theory, which was based on superiority and ethical correction, to a comedy of incongruity, which may invoke affection as well as laughter. This "Amiable Humor," as coined by Tave, encouraged sympathetic laughter and discouraged the punitive laughter, ridicule, and satiric wit of earlier eras which often served to challenge authority and authoritative figures.
} 
Medusa," theorizes that women's writing is "precisely the very possibility of change, the space that can serve as a springboard for subversive thought" (879). Hélène Cixous describes women's laughter as wanting "to smash everything, to shatter the framework of institutions, to blow up the law, to break up the 'truth' with laughter (1976 888). Similarly, feminist humor theorists such as Nancy Walker and Regina Barreca theorize that women's humor is always subversive. In A Very Serious Thing Nancy Walker states that women's political and domestic humor has always been an effective challenge to long-held and oppressive ideas. These theories surrounding the potential subversiveness of women's humor are vital to my study as I analyze how female comic grotesque characters invert gender and class hierarchies. These inversions and the comedy surrounding them are transgressive as they defy social and political structures.

During the late eighteenth and nineteenth centuries female laughter was discouraged as it was considered disruptive to the social order. Late eighteenthcentury conduct books, for example, admonished women about the dangers of their use of wit. James Fordyce, in his 1767 Sermons to Young Women, warned women about employing humor saying, "men of the best sense [are] usually averse to marrying a witty female" (191). Further, he warned of the man's unhappiness while married to a witty woman, saying a man who marries a witty woman "has found a perpetual satirist; or a self-sufficient prattler" with whom he cannot be happy (193). ${ }^{6}$

\footnotetext{
${ }^{6}$ Thomas Gisborne in his 1797 An Enquiry into the Duties of the Female Sex agrees with Fordyce stating, "If wit be continually exercised in ridicule and satire...is it wonderful that the husband should regret that it had been granted to his associate?" (267).
} 
Laughter was also considered dangerous for a young woman's reputation. In his $A$ Father's Legacy to His Daughters (1774), John Gregory warned young woman against getting carried away by group laughter. Even when a "girl laughs with the simplicity of unsuspecting innocence...being infected with other people's laughing; she is then believed to know more than she should" (59). Female humor in this period was not only discouraged in social situations but it was also problematic for female authors to employ satirical humor which criticized the status quo. In her study of feminine humor in nineteenth-century authors, Eileen Gillooly writes of the "drastic decline" of the intellectual freedoms of "humor wielding" women writers by the end of the eighteenth century (3). She cites civil unrest in England and revolution abroad as the incitement for a "reactionary rigidification" of social codes along gender lines (3). As a result, female authors who engaged in wit and political satire or any hint of bawdy humor "became bywords for female abomination" (3).

Despite these restrictions, Gillooly argues for feminine humor's undercover ability to ridicule the patriarchal authority and the "cultural construction of femininity" (4). Therefore, feminine humor "allows its practitioners to express what would otherwise be repressed or prohibited" (xxv). Similarly, Audrey Bilger argues for the feminist potential in female humor stating, "humor can serve as a psychological survival skill and an emancipatory strategy for women" during the eighteenth and nineteenth centuries (11). Further, during time periods when "overt feminist statements" could ruin a women's reputation, comedy furnished authors with a means for "smuggling feminism into their novels" (11). Both Gillooly and Bilger point to the relatively little 
critical attention received by the humor of female authors. Similarly, two of the comic authors I analyze, Emily Eden and Catherine Gore, are not canonical and have received little critical attention. On the other hand, literary critics have given Frances Trollope more attention, but, beginning with her own son's rather harsh criticism, her work has not been considered canonical.

Although Bilger argues for the potential feminism in women's comedy, she also recognizes that "comedy can also be enlisted for conservative ends, to preserve order and to uphold the status quo" and that within some texts, "rebellious humor can stand alongside conservative tendencies" (9). In my dissertation I argue as Bilger does that subversion "is not inherent in comic expression, but comedy can serve as an excellent vehicle for making radical ideas palatable to an audience that might otherwise be offended by them" (9). Although I examine the potential for challenges to authority contained in the comic grotesque, I do not assume that all female comic grotesque characters serve a subversive function. I also do not assume that these comedic challenges have more than a temporary effect.

\section{Grotesque Imagery in the Material Body}

Bakhtin's theory of the grotesque focuses on the material body, specifically on the lower stratum. This focus is important to recognize because my study includes several comic characters who are grotesque because of their corpulent bodies. As Brad Epps correctly states, Bakhtin "celebrates the low, burlesque, earthy, realist body as the very substance of the grotesque" (46). Bakhtin analyzes the grotesque in relation to the culture of Medieval and Renaissance folk humor and the spirit of 
carnival with its "lowering of all that is high, spiritual, ideal, abstract...to the material level" (19). Bakhtin referred to this aesthetic concept as characteristic of folk culture and termed it as the Material Bodily Principle. According to Bakhtin, grotesque imagery is dominated by the body's orifices--the mouth, the belly, and the genital organs. The main events in the life of the grotesque body revolve around these areas and include eating, drinking, giving birth, defecating and other elimination (sweating, blowing the nose, and sneezing) as well as copulation and pregnancy (26). Mouths, noses, buttocks and genitals as well as their physical functions frequent the imagery of carnival (49). Carnivalesque images of the grotesque body were often imbued with "exaggeration, hyperbolism...[and] excessiveness" (303). Thomson argues that the carnival is "grotesque par excellence, a place where common people abandoned themselves to exuberantly obscene excesses of a physical kind" (56).

Bakhtin focuses on the lower body or the "lower stratum" in the grotesque imagery of carnival in contrast to the upper part-the face and head. Bakhtin contrasts the grotesque body with the symmetry, beauty and smoothness of the classical body. According to Stallybrass and White, Bakhtin is struck by the contrast between how the human body, the "low" body, is represented in popular festivities and the classical, harmonious, clean representations of the body in classical and Renaissance statuary (21-2). While the classical body is closed off with no openings or orifices, the "grotesque costumes and masks [of carnival] emphasize the gaping mouth, the protuberant belly and buttocks, feet and the genitals" (22). Further, 
Bakhtin describes grotesque images as "ugly, monstrous, [and] hideous from the point of view of classical aesthetics, the ready-made and completed" (25).

The binary between the classical and grotesque body and between the high and low body, reflects the binary Bakhtin theorizes between the material (grotesque) imagery of folk culture and the "spiritual imagery of the Church" (401). As I discussed earlier, Bakhtin differentiates between the repressive, hierarchical society of officialdom and the nonofficial freedom of carnival festivities. Similarly, the lower body of the grotesque relates to the "lower body of society, the peasantry, which was both a prime source and subject of the carnivalesque" (Connelly 85). As I will discuss in Chapter Two, this relationship between the peasantry and the grotesque resonates with cultural attitudes toward the obese; in the nineteenth century, as in the twentieth and twenty-first centuries, excess weight was considered a characteristic associated with the lower classes.

Bakhtin argues that the dynamism of the grotesque body represented an alternative to the stasis of the official order, because it is a "body in the act of becoming. It is never finished, never completed; it is continually built, created and builds and creates another body (317). The grotesque body is preoccupied with physical functions, such as eating, drinking and giving birth, which are dynamic processes of interaction between the body and the world. Similarly, while official culture attempted to "portray social relations as natural and unchanging," grotesque imagery, in contrast, represented the extent to which human existence was bound up with processes of transition (281). Bakhtin points to the Kerch terracotta statue of 
laughing, senile, pregnant hags as a "typical and very strongly expressed grotesque. It is ambivalent. It is pregnant death, a death that gives birth" (25). Bakhtin terms this incompleteness as the epitome of the grotesque body.

Just as Bakhtin termed carnivalesque laughter as universal, he describes the bodily element as something universal, representing all the people--not a private egotistic form severed from other spheres of life. While the leading themes of these images of bodily life are "fertility, growth and a brimming over abundance, they refer not to the private, egoistic, economic man but to the collective ancestral body of all the people" (19). As Stallybrass and White state, Bakhtin insists on the "relation between body image, social context and collective identity" (10). They conclude, therefore, that "body images speak social relations and values with particular force" (10). I have found Bakhtin's understanding (and that of Stallybrass and White) of the body as a locus of social meaning enormously generative for my work. This dissertation leans heavily on this fundamental insight.

As I discussed above, grotesque imagery signifies an alternative to the fear inspired by official imagery. While official imagery traded on cosmic threats such as famine, droughts, flood, disease to inculcate a "sublime" sense of fear, grotesque imagery overcame this sense of fear by "assimilating humans with the cosmic elements" (281). According to Bakhtin, grotesque images of eating and drinking were able to represent the way in which a person "triumphs over the world, devours it without being devoured' themselves (281). Grotesque imagery represents an alternative to the symbolism and ideology of officialdom. Frances Connelly argues 
that the grotesque also provides comic relief from manners and social proprieties, much of which centers on keeping control of our bodies and its functions (84). Further, the carnivalesque body can also function as the "quintessential voice of the outsider [from official culture so that] its satire and transgression serving as a powerful agent of change" (84).

Stallybrass and White similarly theorize the grotesque operating as a "critique of a dominant ideology" (43). The dominant culture, they continue, "pretend[s] that critique can only exist in the language of reason, pure knowledge and seriousness" (43). In contrast, Bakhtin emphasizes the logic of carnival, of the grotesque, of excess, and of the lower body. This logic, they conclude, "could unsettle given social positions and interrogate the rules of inclusion, exclusion and domination which structure the social ensemble" (43). Just as comic theorists represent the potential power of laughter to transgress authority, Bakhtin and his followers argue for ability of the comic grotesque to challenge the dominant ideology. In Chapters Two, Three and Four I will analyze comic grotesque characters for this potential.

\section{Bakhtin's Inversion-A Suspension of Hierarchy}

In this section, I focus on Bakhtin's theory of inversions during carnival as it is highly significant for the comic grotesque characters in the novels I study. These characters, following a carnivalesque pattern, perform gender and class inversions which lead to a leveling of traditional hierarchies. Further, as I explain below, gender and class roles were of particular significance in nineteenth century England. During 
periods of carnival festivity, Bakhtin identifies a temporary suspension of the entire official, hierarchical system, so that "all were considered equal" (15). As a result, participants experienced equality and democracy (Yates 23). During carnival, the "norms and prohibitions of usual life" are suspended so that an "atmosphere of freedom, frankness and familiarity" reigned (Bakhtin 15-16). Because of the temporary suspension of hierarchical rank, Bakhtin theorizes the establishment of an "an ideal and, at the same time, real type of communication, impossible in ordinary life" (92). This communication consisted of special forms of marketplace speech and gesture expressed with frankness and freedom, often scatological, which could liberate the people "from norms of etiquette and decency imposed at other times" (10). Further, through the suspension of all hierarchical rank and prohibitions, carnival was a time of "becoming, change and renewal" (10).

The suspension of hierarchical rank arises through an inversion or reversal of hierarchic levels: the jester was proclaimed king; a clownish abbot, bishop or archbishop was elected at the "feast of fools;" in the churches a mock pontiff was chosen; and kings and queens were elected for a day (81). Lower status individuals temporarily assumed authoritative roles and this inversion of status gave them the ability to relate to higher status individuals as equals.

According to Bakhtin, these inversions relate to the grotesque body in that by shifting from top to bottom "the high and the old, the finished and completed [are cast] into the material bodily lower" (81). Stallybrass and White argue that Bakhtin links the inversion of hierarchy with a "comic privileging of the bottom part of the 
body (feet, knees, legs, buttocks, genitals, anus) over the rational and spiritual control of the head" (183). Carnival, they continue, "attacks authority...by the use of masks and costume" and brings about the degradation of status through the exposure of the grotesque aspects of the body (183).

These class inversions, what Bakhtin refers to as a "world inside out," showed the people the possibility of a different societal structure--a world which has reversed the rules and mores of the dominant culture (65). The "peculiar logic" of carnival inversions involved a "continual shifting from top to bottom... of numerous parodies and travesties, humiliations, profanations, comic crownings and uncrownings" (11). The "world inside out" offered an alternative construction of social relations suggesting the official order was not necessarily a given (11). By this means, Bakhtin theorizes, a "counterculture" is created which celebrates the abandonment and excess of bodily activity and gives "recognition and acceptance normally denied" to the body and peasant life (66).

Bakhtin emphasizes both the utopian and the temporary nature of this suspension of hierarchical barriers. The temporary suspension of the official system led to a "sphere of utopian freedom" (89). Additionally, the "very brevity of this freedom" increased its fantastic nature and utopian radicalism (89). The people enjoyed this "atmosphere of ephemeral freedom" in the public square as well as in their private homes (89). According to Neil Ravenscroft, the temporary inversion of the social order in carnival allows ordinary people "to feel that they have some freedoms and they're valued members of the community" (40). This temporary freedom involved 
not only a democratic form of communication between upper and lower classes, as described above, but also a liberation "from the prevailing truth of the established order" (109). The laughing response to inverted and grotesque images "permitted the expression of an...popular truth" exposing the supposed naturalness of the social order as artificial (94). Bakhtin's theory of inversion, similar to his arguments concerning laughter and the material body, emphasizes the potential transgressive nature of carnival.

Gender and class roles are especially relevant in early and mid-nineteenth century novels as they were changing during this period. In their groundbreaking study, Family Fortunes, Leonore Davidoff and Catherine Hall theorize that gender roles, especially for the middle class, were in flux between 1780-1850. During this time period, a realigned gender order emerged as existing expectations about the proper roles of men and women were re-worked with a significantly different emphasis (xvi). Between 1780-1850, Davidoff and Hall claim that "family, home, masculinity and femininity were redrawn, negotiated, reformed and reinstalled" (xvi). The notion of separate spheres, although this idea was not invented in the 1780 's, became more solidified during this period.

This time period had significant implications for class affiliation as well as gender roles. Members of the middle class, critical of many aspects of aristocratic privilege and power, sought to translate their increasing economic weight into a moral and cultural authority (30). The middle class strove to "exercise this moral authority not only within their own communities...but in relation to other classes" (30). 
These fluctuations in class and gender roles are especially important to my study as my chosen novels were written during the very same time frame. Specifically, Jane Austen's Persuasion was published in 1816; Emily Eden's The Semi-attached Couple was written in $1839^{7}$ and her The Semi-Detached House in 1859; Catherine Gore's Pin Money in 1831; and Frances Trollope's trilogy, The Widow Barnaby, The Widow Married, and The Widow Wedded; or The Adventures of the Barnabys in America in 1839, 1840 and 1843 respectively.

As I examine comic grotesque characters represented by nineteenth-century female authors, I analyze the freedoms, albeit temporary, related to class inversion. I argue that these inversions, along with the characters' grotesque qualities, allow these characters to enjoy the benefits of a higher status. More specifically they realize a shift from the middle-class existence to an upper-class experience. Through this shift, the reader as well as the characters of the novel are exposed to the artificiality of class structure and led to question its supposed naturalness. I also examine gender inversions in addition to class inversions in these novels. Although Bakhtin focuses primarily on class inversions, the work of Natalie Zemon Davis emphasizes the prevalence of gender inversions in carnival. I discuss Davis' study in more detail below in my discussions of the Feminine Grotesque and Inversions. Finally, I examine inversion in terms of its use in anthropological theory and its temporary and potentially liminal nature.

\footnotetext{
${ }^{7}$ Although The Semi-Attached Couple was published in 1859 , it was written twenty years earlier in 1839.
} 
Bakhtin's discussion of hierarchical inversions, replacements of official imagery with grotesque imagery, and the democratic freedom of the marketplace during festive days, suggest that the carnival and the grotesque might act to subvert authority. Grotesque imagery provided a challenge to official images of spirituality, stasis and fear, while carnival laughter had the potential to demystify the power and the "naturalness" of political and social structures, and inversions of hierarchy threatened the authority of the upper classes. In addition, Bakhtin claims that carnival had two faces; one was "its official, ecclesiastical face" which "was turned to the past and sanctioned the existing order" (88). The other face was "the [unofficial] face of the people of the marketplace" which looked to the future (88). This suggests the future will move away from authoritative structures toward a more free culture. Carnival laughter, he argues, "builds its own world in opposition to the official world, its own church versus the official church, its own state versus the official state" (88). Similarly, Dominick LaCapra suggests that "carnivalesque phenomena in Bakhtin" test and contest all aspects of society and culture through festive laughter (Ashley xx). LaCapra points to Bakhtin's vision of a "utopian dimension, an experimental fantasy," that explores possibilities of historical transformation (Ashley xx).

Bakhtin represents the licensing of carnival as "not a static state of affairs but an ongoing process of negotiation" (90). These negotiations led to struggles and new prohibitions. The ecclesiastical and state authorities were "obliged to make concessions to satisfy the marketplace" during medieval period (90). On the other hand, social historians of England and other European countries identify "ongoing 
battles waged by the State, ecclesiastical and bourgeois authorities against popular custom," especially during the Renaissance (Stallybrass and White 15). In reaction, carnivals and festivals became politicized by the very attempts made on the part of local authorities to eliminate them. Because of the "intervention by higher powers," carnivals became sites of resistance even without any previous opposition

(Stallybrass and White 15). These historical negotiations strengthen the theory of carnival as oppositional and rebellious. ${ }^{8}$

Several theorists point to the temporary nature of carnival to argue that any challenges to the authority of the official society are only fleeting and relatively ineffective. The temporary nature of subversive challenges in carnival echoes the temporary nature of the transgressiveness of the comic grotesque characters in the women's humorous novels I study. Specifically, the characters' class and gender inversions, with the exception of those of the Widow Barnaby in Trollope's trilogy, revert to traditional hierarchies by the end of the novels. Bakhtin, for example, refers to carnival as a "temporary liberation from the prevailing truth and from the established order; it marked the suspension of all hierarchical rank, privileges, norms and prohibitions" (10, emphasis mine). Erica Brown points to Bakhtin's use of the terms suspension and temporary and argues that carnival "can thus be seen as a way

\footnotetext{
${ }^{8}$ Although these representations of laughter and grotesque imagery in carnival seem to suggest an oppositional, rebellious potential in carnival, many scholars argue against this view of carnival. One argument against this rebellious potential is that carnival is licensed by authorities and, therefore, according Terry Eagleton and others, carnival amounts to "nothing more than a safety-valve, whereby the discontent of the people might be siphoned-off peacefully" (Taylor 48). This "safety-valve" theory acknowledges that carnival might allow for a "hot-bed of satire," but ultimately it is no more than comic relief (Taylor 48). Theorists who ascribe to this argument view the relief of the people's discontent as actually strengthening rather than threatening the power of officialdom.
} 
of containing or defusing radical impulses" rather than a challenge to the established social order (21). Similarly, the authors of the novels I analyze avoid a reputation for subversiveness by limiting it to temporary transgressive behavior on the part of minor comic characters.

Although Bakhtin argues that hierarchal inversion and the people's freedom is only temporary, he also suggests that carnival produces new social and cultural possibilities. The principle of laughter and the carnival spirit on which the grotesque is based frees human consciousness, thought and imagination for new potentialities. Great changes, Bakhtin claims, even in the field of science, are always "preceded by a certain carnival consciousness" that prepares the way (Bakhtin 49).

Some historians argue that the safety valve or temporary nature of carnival is only part of the potential rebellion of carnival. Peter Burke, for example, points to the temporary nature of resistance in comedies performed during carnival which are built around role reversals but "frequently end with a reminder to the audience that it is time to set the world the right way up again" (202). On the other hand, Burke identifies several examples of carnivals where the "ritualized expression of rebellion" boiled over into actual unrest (202). In fact, the carrying of arms at times of carnival was prohibited in some regions in order to stave off the possibility of riots breaking out. Taylor points to Le Roy Ladurie's analysis Carnival in Romans as an illustration of how carnival might serve as a focus for unrest. Ladurie reports on the 1580 festival in Romans, France, which turned into armed conflict and led to the massacre of the 
peasants. In these cases, carnival needs to be seen as more than a mere festive safety-valve. $^{9}$

How much effective change can be brought about by carnival's resistance to official authority? Gabriela Castellanos sees the carnival laughter as a form of resistance which the "dominant ideology must in turn reckon with and respond to" and as a result this ideology does not remain "monolithic and unchanged" (7). Castellanos cautions, however, that these changes "are not equal to a triumph, to a defiant declaration of independence, to a definitive achievement of freedom" but these alterations cut "fine cracks in the monolith"(7). I find Castellanos' image of carnival's radicalism quite evocative as I examine carnivalesque (grotesque) characters for how they may oppose the dominant ideology of the mid-nineteenth century. In my study, I look for how challenges to social or political conventions may result in "cracks in the monolith" rather than large subversive effects. More specifically, I analyze how comic grotesque characters may transgress gender and class roles and lead the reader to question these roles while the novels in which they appear are not considered subversive.

\section{Feminist Interpretations of the Grotesque}

\footnotetext{
${ }^{9}$ Several scholars of carnival (Stallybrass and White; Chedgzoy; Davis; Castellanos) do not view carnival laughter and grotesque images as "intrinsically radical or conservative" (Stallybrass \& White 14). Carnival may be a stable and cyclical ritual with no noticeable transformative events but, in the presence of sharpened political antagonism, it may often act as "catalyst and site of actual and symbolic struggle" (Stallybrass \& White 14). According to Kate Chedgzoy, much of the scholarly work on carnival has "circled round the desire," encouraged by the idealistic and populist mood of Bakhtin's work, to locate early modern festive practices as a site of popular resistance to an oppressive, hierarchical social order (4). Chedgzoy sees this as problematic because carnival served a range of political purposes both "oppositional and reactionary, progressive and conservative" (4). In her study of carnival in early modern France, Natalie Zemon Davis argues that festive life is not just a "safety valve" which deflects attention from social reality. While it can perpetuate certain "values of the community (even guarantee its survival)," it can also criticize political order (97).
} 
Bakhtin's grotesque body was, according to some scholars, a female body. ${ }^{10}$

Several theorists (Connelly 2012, Miles 1997, Shapira 2010, Russo 1994, Covino 2000)

stress, however, that in Western culture in general the grotesque body is always seen

as a female body. Frances Connelly, using examples from Horace and Aristotle,

argues that the grotesque is bound to the feminine body in Western culture. Horace,

for example, visualized the grotesque as a monstrous, shape-shifting woman.

Aristotle saw a woman's body as monstrous by nature, a deviation from that of the

normative male. Margaret Miles agrees with Connelly, stating that from the

collective male perspective, the most concentrated sense of the grotesque comes,

not from "exotic and distant" monsters, but from the figure "woman" (88). Further,

Connelly argues that the feminine body is most frequently portrayed as monstrous

when it breaches imposed social and cultural boundaries. Yael Shapira concurs,

pointing to a powerful link between women's unstable, "disgusting" bodies and their

\footnotetext{
${ }^{10}$ Feminist scholars argue that Bakhtin's theory displays misogyny and/or ignores the gendered nature of his theory of the grotesque. For example, Bakhtin's quintessential image of the grotesque body is his description of the Kerch terracotta figurines representing senile, pregnant hags. Ruth Ginsburg renames Bakhtin's material bodily principle as the maternal bodily principle because she sees the maternal body as the center of grotesque imagery noting that Bakhtin's text is obsessed with pregnancy and birth. Similarly, Kathleen Rowe defines the grotesque body as the maternal body, which through menstruation, pregnancy, childbirth and lactation, "participates uniquely in the carnivalesque drama of becoming, of inside-out and outside-in, death-in-life and life-in-death" (33-34).

Yael Shapira highlights the "gendered and derogatory nature" of Bakhtin's use of the pregnant and senile hags as the typical grotesque (53). Shapira cites Mary Russo's statement that the hags are "loaded with all the connotations of fear and loathing around the biological processes of reproduction and of aging" (63). Further, Shapira postulates that the image of the female body dominated by gaping orifices and biological flux is part of the "historical arsenal of misogyny a way of grounding women's 'aberrance' in their distasteful corporeality" (53). Grotesque female bodies, Shapira continues, are not only aberrant physically but are frequently correlated with "disorderly behavior - promiscuity, verbosity and gluttony" (53). As I will discuss in Chapters Two, Three and Four, female grotesque characters in nineteenth-century literature are very much associated with the disorderly behavior of excessive talkativeness and excess weight from overeating.
} 
violation of social norms (52). This link not only suggests the degradation of women and their bodies, but also the transgressive nature of women I discuss below.

Several scholars (Mary Russo 1994, Kathleen Rowe 1995 and Yael Shapira 2010) expand on the work of Bakhtin and theorize that the female grotesque or unruly woman $^{11}$ may have a subversive or transgressive potential in literature and in life. They examine the power of female grotesques and female laughter to challenge social and symbolic systems that keep women in their place. In her article analyzing the grotesque in Margaret Atwood's "Hairball," Shapira debates whether literary manifestations of the grotesque supports or challenges the status quo. She proposes that the image of the unruly woman and her changing open-ended body can "subvert rather than affirm a norm that preaches discipline and containment" (54). These are questions which I seek to answer, in Chapters Two through Four, regarding nineteenth-century female comic grotesques. In the discussion below, I present and analyze the work of scholars who study these questions.

Mary Russo theorizes that the history of literary and artistic representation, as well as the history of public and political discourses, reflects and reinforces the imperative that women keep themselves small and unseen, that they neither take up too much space in the world, nor make spectacles of themselves. She describes a spectacle as a woman who transgresses norms through their appearance and/or their behavior. As a potentially subversive alternative, Russo prefers that women make themselves "prodigious and visible, that they seek majesty, and so disrupt long-

\footnotetext{
${ }^{11}$ The term "unruly woman" is used as synonym for, or at times a close relative of, the female grotesque
} 
standing definitions of the ideal woman as restrained and diminutive" (Covino 3). For example, in her chapter on early women pilots, Russo admires Amelia Earhart's aerobatic stunting for its refusal of conventional femininity.

Russo rehabilitates the identification of the grotesque--noted by Bakhtin-with "the lower bodily stratum and its associations with degradation, filth, death, and rebirth" (62). She argues that traditional aesthetics have devalued the grotesque body, in preference to the classical body, which is "identified with the 'high' or official culture of the Renaissance and later, with the rationalism, individualism, and normalizing aspirations of the bourgeoisie" (63). By contrast, she associates the grotesque body, "open, protruding, irregular, secreting, multiple, and changing," with the "social rebirth and reformation" called for by "the non-official 'low' culture or the carnivalesque" (63). Russo suggests that the Western ideal, which relies on "normalcy, purity, and transcendence," constructs itself in opposition to the qualities with which the grotesque is associated: "the abnormal or perverse, the filthy or tainted, and the earthly or grounded" (7). Russo's liberation strategy for women is through the grotesque; she sees power in representations of the female body as grotesque (13).

Russo also suggests that the discourse of carnival moves to "models of transformation ...situated within the social system and symbolically at its margins" (54). On the other hand, an examination of the theories on carnival can recall "limitations, defeats and indifferences generated by carnival's complicitous place in dominant culture," especially for women and other marginalized groups (56). Russo 
sees in Bakhtin's work "an ambivalent redeployment of taboos around the female body as grotesque (the pregnant body, the aging body, the irregular body) and as unruly in the public sphere" (56).

In addition to her analysis of Bakhtin, Russo studies Natalie Zemon Davis' work on carnival, "Women on Top," in which Davis studies Medieval festivals in France and England and discusses the implications of gender inversion and transvestitism in terms of the subversive potential of the female grotesque. Natalie Davis argues that comic and festive gender inversions could undermine as well as reinforce the power structure of society. Davis finds that the image of the disorderly woman did not always function to keep women in their place, but it was a multivalent image that could operate, first to widen behavioral options for women within and even outside marriage, and second to sanction riot and political disobedience for both men and women in a "society that allowed the lower orders few formal means of protest" (58). Play with an unruly woman in carnival, she concludes, is partly a chance for temporary release from the traditional and stable hierarchy, but it is also part of the conflict over efforts to change the basic distribution of power within society" (58). I will discuss Davis' work in more detail below.

Kathleen Rowe examines the power of female grotesques and female laughter to challenge the "social and symbolic systems" that work to keep women in their place (3). Although women have traditionally been represented as objects rather than as subjects of laughter, Rowe theorizes that "structures for expressing women's anger exist in the genres of laughter" (8). Laughter, she states, might help "loosen the bitter 
hold of social and cultural structures" that have repressed women for centuries (3). She defines the female spectacle-making performed by the unruly woman as a "kind of transgressiveness and ambivalence" associated with social and literary traditions of carnival or what might be called the "genres of laughter" (3). According to Rowe, female spectacle making renders women vulnerable to "ridicule and trivialization, but it can also make women vaguely demonic or threatening" (3).

Rowe defines the unruly woman as dwelling close to the grotesque through her association with both beauty and monstrosity (11). Rowe argues that the Medusa, like Bakhtin's grinning hags, contains the earliest outlines of the unruly woman, an "ambivalent figure of female outrageousness and transgression with roots in narrative forms of comedy and the social practices of carnival" (10). Although Rowe does not reference Cixous directly, her description of the Medusa resonates with Hélène Cixous' "The Laugh of the Medusa." Unlike the Medusa, who was doomed in mythology, the unruly woman can enjoy a reprieve from fates for women in patriarchal society, because her home is "comedy and the carnivalesque, the realm of inversion and fantasy where, for a time, the ordinary world is topsy turvy" (11). According to Rowe, the effect of women making jokes about men temporarily inverts the social hierarchy. She argues that the figure of the unruly woman-too fat, too funny, too noisy, too old, too rebellious - unsettles social hierarchies (19).

Like Russo, Rowe turns to Davis' work because Davis extends Bakhtin's theory of carnival and the grotesque to gender and gender inversions. Rowe sees the woman on top as "characterized by excessive size, excessive garrulousness or both" (37). The 
unruly woman, she postulates, eats too much and speaks too much - both transgressions involve "failure to control the mouth" (37). The female grotesque characters in my study certainly align with this definition of the unruly woman. As I demonstrate in Chapter Two, Mrs. Hopkinson in The Semi-Detached House, and Mrs. Musgrove in Persuasion are excessive eaters. In Chapter Three, Mrs. Douglas and Lady Portmore in The Semi-Attached Couple are excessive talkers. Finally, Mrs. Barnaby from the Widow Barnaby trilogy, analyzed in Chapter Four, exhibits a total inability to control her mouth-she eats and speaks too much. In these chapters I argue that female comic grotesque characters are able to unsettle social hierarchies, but in some novels their transgressiveness has only a temporary effect.

\section{Inversion: Reversing Social and Cultural Norms}

In this section, I build on Bakhtin's theory of inversion in carnival to explicate a general definition of the term, to explore its relationship with comedy, and to extend Bakhtin's class-based inversions to gender inversions. Anthropologists such as Barbara Babcock and Victor Turner discuss the importance of inversions in culture and define it as an "act of expressive behavior which inverts, contradicts, abrogates or in some fashion presents an alternative to commonly held cultural codes, values and norms...linguistic, literary or artistic, religious, or social and political" (Babcock 14). Further, according to Rosalie Cole, inversions are the world turned upside down, an environment that contrasts sharply "with the way the world is commonly experienced" (Babcock 16). These definitions share the notion of turning the world upside down and reversing cultural and social norms. 
The term inversion is also used to describe a central principle of comedy.

According to Henri Bergson, for example, the comic principle of inversion involves an unexpected and humorous switching of normal roles where, for example, "prisoner reprimands judge, child rebukes parent, wife rules husband, pupil instructs teacher, [and] master obeys servant" (Babcock 15). For Bergson as well as for Freud, the essence of laughter-producing "topsyturvydome" is an attack on control, on "the irreversibility of the order of phenomena" (Babcock 15). Inversions, therefore, are part of humor's potential to challenge cultural norms. ${ }^{12}$

As I already discussed, Bakhtin sees inversions as a significant element in the freedom and democracy of carnival. Although Bakhtin emphasized the importance of inversions, he focused exclusively on class inversions, thereby ignoring gender inversions. Natalie Zemon Davis fills in that gap in her study of gender inversions occurring at carnival and other festive occasions as well as in actual riots and protests against authorities. In Davis' study the "woman on top" appeared in several variations which violated the "natural order" including women who assume male

\footnotetext{
${ }^{12}$ Through these reversals of cultural norms, culture frees itself from its rules and prohibitions and "enables itself to speak about itself" (Babcock 21). Inversive images such as clowns or transvestites remind us of the "arbitrary condition of imposing an order on our environment and experience" and at the same time enable us to see our environment and its rules more clearly simply because they have been turned inside out (Babcock 29). Victor Turner argues that inversion may "break people out of their culturally defined, even biologically ascribed roles by making them play precisely the opposite roles" (1972 287). Inversion may break down the barriers of age, sex, status, class, family, and so on to teach the meaning of "generic humanity" (1972 287). Similarly, Stallybrass and White postulate that inversion is an important symbolic process as it reorders the "hierarchy of a binary pair" (56). They argue that inversion, therefore, could be mobilized as a way of "remodeling social relations" such as "husband and wife, old and young, animal and human, master and slave" (56). These theorists, like Bakhtin, agree on the potential of inversions to enable participants to view their social and political relationships with more clarity and thus may demonstrate possibilities for a different societal structure.
} 
positions of authority (and masculine clothing) and men who masquerade as women. Cross dressing by men and women was a common means of effecting gender inversion. A man, by disguising as a woman, could appropriate the "inherent unruliness and dangerous disorderliness" of women in the safety of his own disguise (149). Men who challenged authority while dressed as women escaped full responsibility for their actions because they were viewed as "mere women acting in a disorderly way" (149). For a woman, gender inversion meant not so much disguising herself as a man but, more radically, giving rein to the "wild" lower part of herself and seeking power over others. The sexual inversion of women trying to act like men yields "criticism of the established order" (132). According to Davis, these role reversals could inspire women and cause "feminists to reflect on capacities of women," but it is unlikely they became "symbols for moving masses of people to resistance" (132). The possibility for change arises but usually does not lead to subverting official authority or prescribed gender roles.

Davis finds that in preindustrial Europe gender inversion, was a "widespread form of cultural play" in literature and art as well as in carnival (128). In her study of gender inversions in literature of early Modern Europe, Davis identifies their providing "outlets for conflicts about authority" within the system; literature also provided occasions by which the "authoritarian current in family, work, and political life could be moderated by the laughter of disorder and paradoxical play" (142). In this way they served as safety valves to reinforce hierarchical political and social structures. On the other hand, Davis argues for literary and festive gender inversion 
as a product not just of stable hierarchy, but also of changes in the "location of power and property," so inversion could prompt new ways of thinking about the system and reacting to it (143). Therefore, gender inversions, similar to laughter and to class inversions, can both undermine and strengthen the power structure of society. As I stated earlier, my study includes an examination of gender inversions in Chapters Three and Four. Although the comic grotesque characters do not engage in crossdressing as in Davis' study, they do assume traditional male responsibilities and, in doing so successfully, work to undermine the separate spheres ideology of the nineteenth century.

Babcock suggests that within a ludic frame, inversions which may challenge power structures can be presented "paradoxically" and without threat (24). Some psychologists, literary critics and anthropologists regard inversions as a fundamental form of "play" and as a means of inducing play. Babcock defines play as, the "freeing of focused energies within a restrictive environment in which social threat can paradoxically be expressed without threatening" (24). For example, Erik Erikson in "Play and Actuality" suggests that by allowing us to engage in "reversible operations," inversions create "Spielraum, a space in which to take chances with new roles and ideas" (25). According to Erikson, inversions can mock norms of our lives and they can also reinvest our lives with a "vigor and a Spielraum attainable in no other way" (32). Play, as I discussed earlier, is also a vital component in definitions of the grotesque. 
John Ruskin, for example, stresses the combination of intellectual play and terror as an essential part of the grotesque, stating that the "mind under certain phases of excitement, plays with terror" (McElroy 1). For Ruskin, grotesque art is a product of a strong urge to play, invent, and manipulate. As we have seen, the grotesque work of art or literature combines two elements: the sportive or ludicrous and terrible or horrible. According to Ruskin, few grotesques are "so utterly playful as to be overcast with no shade of fearfulness, and few so fearful as absolutely to exclude all idea of jest" (Hollington 198). Even the terrifying grotesque, therefore, contains some element of play.

According to Connelly, the essence of the grotesque is to put things into play. Further, the operations of the grotesque pry open a "Spielraum," creating "elbow room" or "room to play" (12). This term describes the "creative possibilities of play" in human and cultural development (12). Connelly argues that the subversive grotesque puts social roles, hierarchies, and "cultural conventions into play, challenging the limits of propriety" and creating new possibilities (14). I am most interested in the creative possibilities of play as they apply to the comic grotesque characters in my study as I analyze their ability to invert and challenge class and gender categories.

Victor Turner relates both play and inversion to the liminal. In fact, Turner views play as "a liminal or liminoid mode, especially interstitial, betwixt-and-between all standard taxonomic notes, essentially elusive" (Connelly 12). In addition, Turner writes of inverse behavior as a central component of the liminal period of rites of 
passage (Babcock 24). Further, he argues, role reversals are confined neither to primitive cultures nor to traditional rituals. Therefore, I now turn to an analysis of liminal spaces.

\section{Liminal Space and its Relationship to the Grotesque}

Several theorists of the grotesque (Connelly 2012, Hume 2011, Russo 1994, Thomson 1972) argue that the grotesque works at the boundaries and results in a liminal space. The term "liminal" originated in the early twentieth century with anthropologist Arnold van Gennep's theory of a three-stage tribal ritual. Van Gennep found that rites of passage (rites which accompany every change of place, state, social position and age) in many cultures have a tripartite structure: separation; margin (or limen) and re-aggregation. The process of transition which takes place in the second part of rites of passage is liminality. Van Gennep's theory was largely ignored during the early to mid-twentieth century until Victor Turner brought it into mainstream anthropology.

During the mid to late-twentieth century Turner expanded on van Gennep's theory. Although he first wrote about liminality in terms of his study of the Ndembu tribe, Turner repeatedly identified parallels with non-tribal or modern societies, clearly sensing that what he argued for the Ndembu had relevance far beyond the specific ethnographic context (Thomassen 14). Because of Turner's work, modern applications of the concept of liminality include work in anthropology, psychology, literary studies, organizational theory, and business consultancy (Thomassen 18). 
Turner makes it clear that liminality applies to modern society as well as to ritual in tribal societies, especially in the realms of art and leisure activities.

Turner describes the liminal as a state associated with margins, transitions and thresholds. Liminal spaces or times exist on the edge of normal activities and, like the grotesque, are marked by contradiction and ambiguity. Turner conceives of liminality as a state "betwixt and between" the normal, day to day cultural and social states, a time of enchantment when "anything might happen" where new combinations of cultural givens could be playfully tested (1979 465). Like inversion, liminality is full of potentiality, experimentation, and the play of ideas. Just as play or Spielraum is an important element of inversion and the grotesque, Turner argues it is a vital part of liminality.

Liminality as a concept applies not only to situations but also to individuals. Turner calls liminal individuals "threshold people" and finds they are betwixt and between the positions "assigned and arrayed by law, custom, convention and ceremonial" (Turner 1969). In her study of liminal characters in Victorian novels, Sarah Gilead argues that the liminal figure, who seems to be outside the group, is actually its moral representative. Further, this figure exists to serve the social structure from which he seems to have been separated. The liminal figure in literature provides the reader with a "vicarious experience that offers a kind of safety valve for the hostility or frustration engendered by the limitations of structured life" (184). The liminal process creates a "safe game-space for the putting-into-play of values or behaviors" contrary to political and social power structures. The existence of that game-space, 
however, actually strengthens power structures by "satisfying egalitarian...longings" within the liminal. Therefore, social rules, categories, classes, and institutions are strengthened by "enacting a fantasy of their weakness" (184). Liminal characters, often portrayed as outsiders or rebels, therefore, come to "embody the communal wisdom he had transgressed" (185). For Gilead, liminality opens up temporary possibilities for change, but ultimately, she views it as strengthening the status quo.

In his analysis of the unruly female in Davis' "Women on Top," Turner suggests that unruly women in carnival are "quintessentially liminal" by reason of their "status inferiority and marginality" (1979 478). This unruliness itself is a mark of the ultraliminal, of the perilous realm of possibility of "anything may go" which threatens any social order (1979 478). The powers of the weak-to curse and criticize-set limits on the power of the strong-to coerce and ordain (Turner 1979 478). Mary Russo agrees with Turner, but emphasizes that women and their bodies "in certain public framings, in certain public spaces" are in danger as well as dangerous (60). She cites Emmanual Le Roy Ladurie's work in Carnival at Romans which recounts specific examples of violence towards women during carnival festivities.

As I discussed above, the disparate elements of the grotesque, the ludicrous and fearful aspects, interact but remain in a state of tension and are unresolvable. This unresolved conflict element of the grotesque suggests that the grotesque is a liminal state. Kathryn Hume conceptualizes the grotesque as three distinct parts: two values in opposition to one another create a third space, the grotesque, which arises from the tensions between the two values. Hume states that because the fusion or 
reconciliation of these disparate values is impossible, the grotesque creates a liminal space (82). Sylvie Henning describes the grotesque in similar terms, as encompassing within itself both "members of an antithesis" and revealing the "tense interplay between the same and different" (119). The indeterminacy of the grotesque suggests that it would always be incomplete, always "transgressing the limits of categorization and logic" (119). It remains, therefore, in an in-between state suggestive of the liminal.

Bakhtin, in fact, essentially describes the temporary nature of carnival in terms of a liminal space: a time of play, freedom and possibility. Frances Connelly defines the grotesque by "what it does to boundaries, transgressing, merging, overflowing, destabilizing them" and states that the grotesque represents a "constant struggle with boundaries of the known, the conventional, and the understood" (4). Further, Connelly theorizes, by blurring categories, the grotesque pulls us into a liminal state of multiple possibilities (5). Similarly, Geoffrey Harpham defines grotesque bodies as "stand[ing] at the margin of consciousness between the known and the unknown, the perceived and the unperceived" - a definition highly suggestive of liminality (1982 3). Connelly and Harpham's references to boundaries, margins, and boundary creatures closely aligns the grotesque with liminality.

Ruskin thought of the grotesque as a gap, one of potential and choice for the observer (Connelly 152). In this gap, the connections are left for the viewer to work out for himself--the essential element of the task was to require the viewer to make their own judgment. The grotesque, Ruskin postulates, challenges the viewer to work 
out what virtue might be and then to choose it. Harpham also focuses on the grotesque as a source of new insight, as "revelatory of hidden truth" for the viewer or reader (1982 46). According to Harpham, the observer of the grotesque must suffer through "the interval of the grotesque" on the way to the "discovery of a radical new insight" (198246). Because liminal states allow society to comment on and critique itself, liminality can, but does not inevitably, have a subversive character. In the following three chapters, I examine grotesque female characters in femaleauthored novels of the mid-nineteenth century. In Chapter 2, I analyze the grotesque in terms of fat female characters and class inversion through Emily Eden's The SemiDetached House and Jane Austen's Persuasion. In Chapter 3, I study shrewish, overly talkative and critical, females and their gender inversions through Catherine Gore's Pin Money and through Emily Eden's The Semi-Attached Couple. Finally, in Chapter 4, I study the comic grotesque as a picaresque heroine through Frances Trollope's Widow Barnaby trilogy. I argue that the grotesque characters and the laughter in these novels allow the reader to recognize and explore the cultural assumptions at work in the nineteenth century and to explore the possibilities of new roles and cultural ideas. My dissertation also argues that both grotesque characters, along with their class and gender inversions in these novels, create a liminal space that allows for the exploration of new social and cultural possibilities in the novel and, perhaps, in the world outside the novel. 


\section{CHAPTER 2}

\section{Fat Females and Class Inversion}

As I discussed in Chapter One, Bakhtin's theory of the grotesque focuses on the material body and its carnivalesque images of excessiveness. The Bakhtinian grotesque, which revolved around the mouth and the belly, was frequently represented as an obese, often female, body. In this chapter, in accordance with Bakhtin's theory of the grotesque, I discuss overweight female characters--Mrs. Hopkinson in Emily Eden's The Semi-Detached House and Mrs. Musgrove in Jane Austen's Persuasion, as representatives of the comic grotesque, in nineteenthcentury novels written by two female authors. Austen and Eden employ their characters Mrs. Musgrove and Mrs. Hopkinson respectively to complicate notions of the comic obese character as merely objects of derision and laughter. These two characters, I argue, are grotesque not only by virtue of their large size, but also carnivalesque through their challenges to societal norms and class hierarchies. Through Mrs. Musgrove, Austen challenges the reader's tendency to mock fat people and view them only as objects of laughter rather than as sympathetic characters. Eden not only presents Mrs. Hopkinson as a sympathetic character but also employs a carnivalesque inversion to challenge, at least temporarily, class hierarchies. In these novels, the unruly body of the comic grotesque character becomes a way for nineteenth-century female writers to experiment with potential freedoms during a time when gender and class roles were being formed. 
Midway through The Semi-Detached House the middle-class Mrs. Hopkinson receives a dinner invitation from her aristocratic neighbors, Lord and Lady Chester. Mrs. Hopkinson exclaims to her husband, "I can't dine out, I'm so fat" (173-4). Captain Hopkinson addresses this exclamation literally by saying she "can't expect to be as slim as 17-year old" and "one meal won't make you fatter" (174). Mrs. Hopkinson retorts, "You know that is not what I mean-but there is the butler and all those footmen, they put me out; and they will snatch my plate before I have finished; there will be strangers who will be sure to wonder where Lord and Lady Chester picked up such a vulgar old woman: and then my face will become quite red" (173-4, emphasis mine). From this brief exchange it is clear that fat in this context is a multilayered concept rather than a simple matter of a few excess pounds or excess calories. Mrs. Hopkinson focuses on her corpulent body as the source of her dis-ease in social settings, not only among her aristocratic hosts but their potentially disdainful servants as well. Fat and body theorists, as I explain below, explore the cultural and complex implications of the fat body and the discourses surrounding obesity. In this analysis I concentrate specifically on nineteenth-century attitudes toward the corpulent body and the employment of the Foucauldian disciplines.

\section{Fat Studies and the Victorian Woman's Body}

The relatively new field of fat studies emphasizes the cultural meanings of fatness as well as its materiality. For example, fat theorists Kathleen LeBesco and Jana Evans Braziel ask, "How are discourses (medical, psychological, and capitalistic) deployed in order to contain fat bodies [and] fat people?" (1). Fat studies examines dominant 
ideas about fat bodies as they are "constructed in relation to health and pathology, gender and bodily aesthetics, [and] intersectional identities" (Murray 2012 287). As

Rosemarie Garland-Thomson has observed in her groundbreaking work on disability, Extraordinary Bodies, unusual bodies, including fat bodies, attract intense ideological interpretation. Although the "tyranny of slenderness" as termed by Kim Chernin is considered a twentieth-century phenomenon, many theorists have traced negative discourses surrounding obesity to earlier centuries. ${ }^{13}$ According to LeBesco and Braziel, the meanings of "fat as an encoded surface" shift both historically and culturally, but they are generally negative, so that "fat equals reckless excess, prodigality, indulgence, lack of restraint, violation of order and space, [and the] transgression of [boundaries]" (3).

Nineteenth-century attitudes and discourses surrounding the body reveal an intense interest in the corpulent ${ }^{14}$ body during this period. Elena Levy-Navarro, terms "fat" as an "overdetermined category that has played an important role in development of modernity in the west" and points to the nineteenth century as a period of intensification for the "pathological understanding of fat" (2). Lilian Craton finds that the Victorian relationship to images of physical difference was complex,

\footnotetext{
${ }^{13}$ In "Fat Beauty," Richard Klein explores changes in body size and attitudes toward body size from ancient Greece through the twentieth century. According to Klein, the eighteenth century represented a movement away from overeating toward a greater refinement of taste, but he emphasizes that thin during this period was not as skinny as by our current standards. He associates a "new conception of the relation of mind to body and with it an altered sense of what is beautiful-a new figure of fashion" with the Romantic period (33-34). According to Klein, the Romantic movement "reinvented a Gothic ideal of thin, ethereal beauty, in order to evoke the idea of some edifying elevation beyond the flesh" (34). Between 1800 and 1850, he posits, for the first time in almost four hundred years "the look of thin once more looked beautiful" to contemporaries (35).

${ }^{14}$ According to Joyce Huff, in the nineteenth century the term corpulence denoted an "excess" of body fat, whether or not it was deemed unhealthy; obesity, on the other hand, described a "pathological state" of the body (Huff 20013 ).
} 
"marked by conflicting impulses to reject, exploit and celebrate the odd body" (2009 3). She points to the popularity of freak shows as an example of the fascination that unusual bodies held for Victorian audiences. Similarly, Joyce Huff theorizes the almost obsessive interest both social and medical authorities evinced in body size and proportion in nineteenth-century England.

By the middle of the nineteenth century, according to Joyce Huff, the discourse of fat in Britain posited a body that was separate from and opposed to an interior self, which could and should exercise control over that body. Huff highlights the growing popularity of body management practices like weight-watching ${ }^{15}$. This attitude contrasts with earlier assumptions of fat as an inherited and uncontrollable condition (2010 94). Fat in the nineteenth century was considered the result of the failure of the will to regulate the body properly. Sander Gilman refers to fatness as one of the "diseases of the will" in Victorian psychology (2010 94). A fat body thus became the outward sign of a weak-willed and defective interior "self." As I discuss below, this signification is reflected in the attitudes of the other characters and the narrators toward corpulent characters in nineteenth-century novels.

Pat Rogers traces representations of the corporeal in the novel with a focus on the period from 1750 to 1850 , because these years, Rogers theorizes, include the development of an "awareness of body shape and its relation to a sense of identity" (20). For Rogers, fat is a fictional issue because "the novel is the place where the physical is the sign of the inward" (20). The novel draws increased attention to bodily

\footnotetext{
${ }^{15}$ See Joyce Huff's explication of nineteenth-century weight-watching in "A Horror of Corpulence."
} 
size because of its ability to focus on detail. During the years of Rogers' study, the novel increasingly provides a "bodily schema" which readers learn to interpret (29). Rogers argues that corporeal codes become easier to read in the nineteenth-century novel as more of the personal identity is lodged in the physical shape of characters. Nineteenth-century constructions of corpulence reflected complex attitudes and assumptions. Fatness, especially in men, could be valorized as a sign of health and wealth, but corpulence could also function as a social stigma for men and women. The iconic image of the Victorian female body is an hourglass figure with a small waist and larger hips and breasts. Bordo sees the hourglass figure as "symbolic form," representing a "domestic, sexualized ideal of femininity" (181). Certainly, the larger breasts and hips contrasted against a "fragile wasp waist" emphasize the maternal function. Although the typical mid-Victorian silhouette represents a plump and curvy figure, nineteenth-century culture was not wholly accepting of fat. Huff argues against the belief that, during the nineteenth century, corpulent bodies were thought beautiful through her "analysis of the of the construction of the "proper'" Victorian body (2001b 38). For example, she cites the writing of William Banting, leader of a mid-nineteenth century British diet movement, as evidence that weight reduction was an active concern within Victorian culture.

According to Huff, nineteenth century British people were more ambivalent about female body fat than twenty-first century Americans are; a certain amount of body fat, distributed in the right places, was necessary to obtain feminine beauty (2001a 234). In the Victorian era rules for the "aesthetic distribution of fat" on the body 
were strictly defined (2001b 44). Victorian body management, Huff suggests, was more a matter of "maintaining a properly shaped body rather than maintaining a thin body" (2001b 44). The requirement for this "aesthetic distribution of fat" meant that the "difference between the beautiful and the grotesque" was a difference in degree rather than in kind (2001a 234). Since fat must belong to the beautiful body, the "normal" body sits uncomfortably close to the carnival spectacle of "Fat Lady" (2001a 234). This led to the ambivalence Huff identifies around female corpulence.

Michel Foucault's theory of the body as a focal point for power is particularly important for my reading of the nineteenth-century grotesque body. ${ }^{16}$ In Discipline \& Punishment, Foucault argues that the end of the eighteenth and the beginning of the nineteenth century saw the emergence of the idea of the norm and with it a new type of coercive power--disciplinary power. This modern version of power is nonauthoritarian, not a sovereign power exercised from above, but dispersed throughout practices imbedded within culture through multiple "processes, of different origin and scattered location," regulating the most intimate and minute elements of the "construction of space, time, desire, [and] embodiment" (DP 138). Under this disciplinary power, the body is subjected to a "normalizing judgement that both homogenizes individuals" by defining a universally applicable standard and differentiates them by ranking them according to their difference from an unattainable ideal (Foucault 103). Foucault calls this the docile body, which is regulated by the norms of cultural life.

\footnotetext{
${ }^{16}$ Several theorists of fat studies and the body employ Foucault, including: Joyce Huff, Susan Bordo, Serena Guarracino, Mary Jacobus, Rosemarie Garland-Thomson and others.
} 
Beginning in the eighteenth century, medical discourse classified the body into two categories: the healthy body and the pathological body, and focused on disciplining all bodies in the name of improvement. This view of the body as a productive, well-operating machine produced the idea of a norm used to measure, classify and regulate human bodies. Huff describes how, toward the middle of the nineteenth century, social and biological scientists had become increasingly concerned with "delineating body boundaries," mapping and measuring the human body to determine its "natural" limits (Huff 2001a 28). The imposition of these limits served to naturalize "normative aesthetic standards" (Huff 2001a 28). Body fat became the center of a "discursive and material struggle" to consolidate the identity of "the average body" and limit the amount of space a body should occupy and the resources it should consume (Huff 2001a 28). Because corpulent bodies diverged from the norm by a quantifiable difference, they were often denigrated and stigmatized to "secure the boundaries of the normal" (Huff 2001a 28). Corpulence could, therefore, function as a social stigma. This social stigma against corpulent women clearly operates in both Persuasion and The Semi-Detached House.

The nineteenth century usher in the development of norms for the body as body fat became the focus of various discourses. Between 1830 and 1870, Huff identifies processes of creating norms for the "average body" and of ensuring that "bodily proportion was a major component of the definition" (Huff 2001a 4). New technologies appeared for accurately measuring bodies, such as the widespread use of weighing machines, and for ranking them in relation to the emerging standards. 
During the 1830s, insurance companies formulated the first English actuarial tables for determining ideal proportions, i.e. the ideal body weight in relation to height. Nineteenth-century medical discourses tended to define the norm as a "happy medium"; aesthetic discourses described a body on which fat was distributed in "clearly demarcated proportions" (2001a 4). Both corpulent and too-slender bodies fell outside this narrowly defined average and could be "subjected to a normalizing and stigmatizing stare" (2001b 50). This same period also saw attempts to standardize diet on a national and cultural level through the Poor Law Board's reforms in diet as well as advice on diet in domestic medicine or household management manuals. Fat was singled out as an object of study, participated in by various discourses-social, political, medical, literary and economic.

Huff, through her use of Foucault's theories, focuses on the middle-class engagement in conscious acts of self-fashioning, making its sexuality and hygiene central to the culture and thus securing its hegemony (2001a 3). Throughout the eighteenth and nineteenth centuries, medical discourses played an important role in fashioning the somatic identity of middle-class subjects. Foucault notes that, through the sciences of health and hygiene, medical authority had been extended into the domestic sphere. The middle-class individual, through manuals of domestic medicine, now had access to medical discourses, and these discourses had begun to intervene in the construction of healthy bodies. Bordo similarly terms the practices of body management in the nineteenth century as a middle-class preoccupation where concern with diet became attached to the "pursuit of an idealized physical weight or 
shape" where fat became the "declared enemy" (185). In addition, lower- and middle-class bodies were represented in medical and popular discourses as being fundamentally different.

Expectations for the female body were quite different than those surrounding the male body in the nineteenth century. Anna Silver identifies this period as a time of increased anxiety surrounding overweight bodies with "expectations for the female body intensely debated and loaded with ideological meaning" (qtd. in Craton 2009 90). Michie also terms the Victorian period as a time of "hyperbolic gender difference" with men and women seen as polar opposites (1991 409). Medical, scientific, artistic and philosophical discourses led to the construction of a "culture of separate corporeal realities" such that the bodies of men and women, as well as the poor, the aristocracy and the middle class, were not only treated differently but were thought to have radically different needs and desires coming out of different bodily configurations. Mary Jacobus agrees, pointing to the way scientists and social theorists of the nineteenth century increasingly sought out and "extolled biological evidence of the sexual division of functions in all forms of life, transforming both natural and social existence into one continuous chart of gender polarity" (53). These separate corporate realities, especially those between men and women and the aristocracy and the middle classes, gain significance in the novels I analyze, especially in The Semi-Detached House.

Gendered corporate realities included an increased focus in Foucauldian discipline on the female body. Susan Bordo argues that female bodies have historically been 
significantly more vulnerable than male bodies to extremes in forms of cultural manipulation of the body (1993 143). Because women are both associated with the body (rather than the mind) and largely confined to a life centered on the body (both the beautification of their own bodies and the reproduction, care, and maintenance of the bodies of others), "culture's grip on the [female] body is a constant, intimate fact of everyday life" (1993 17-18). Further, Bordo links control and regulation of the body to the limitation of women's agency and social freedom. Women's conduct manuals with their prescriptions of the correct body and the correct eating methods are a prevalent and highly effective source of disciplinary power.

Nineteenth-century conduct literature provides numerous strictures on female eating and advises women how to consume food in the most feminine way, as little as possible and avoiding the appearance of an inappropriate appetite. In general, nineteenth-century conduct manuals advised that the "well-bred woman eat little and delicately" (Bordo 183). In her 1857 publication, Receipts for the Million, Sara Josepha Hale, the editor of Godey's Lady's book, warned women it was always "vulgar to load their plates" with food (509). Late in the century, 1894, the authors of Talks to Girls by One of Themselves, warned girls to "keep a great watch over your appetite" and "be frugal and plain in your tastes" (104). Mrs. H.O. Ward's 1838 The Lady's Friend depicts every well-provisioned table as a scene of temptation for a lady, which requires fixed (moral) principles and an enlightened mind to withstand (188). For example, the 1887 edition of Modern Etiquette in Public cautions a bride that the most stressful portion of the wedding ritual is the wedding breakfast, when she must 
"bear the attention of her guests focused on her as she eats" (88). These texts frequently associate feelings of shame with the act of eating itself so that the performance of eating in public "transforms a woman into a somehow improper or embarrassing spectacle" (Huff 2001a 235). An unruly or grotesque woman, as I explained in Chapter 1, is a woman who makes a spectacle of herself.

Similarly, the novels of the period rarely depict a middle or upper-class woman eating. Both conduct manuals and novels, therefore, make the restriction of food and the denial of hunger central figures of the "construction of femininity" (Bordo 130). Bordo views this cultural discourse of female hunger as a practical, Foucauldian, "discipline" that educates and trains female bodies in self-restraint and containment of impulse (130).

During the nineteenth century, a female appetite and the act of eating went beyond the risk of creating an unattractive figure; it contained moral implications as well. Michie draws metaphorical connections between female eating and female sexuality. She argues that in the Victorian imagination, the appetite for food often metonymically figured "unspeakable desires for sexuality and power" (Michie 1987 13). Female hunger was thus "displaced from the center of Victorian literature and culture" (Michie 13). The Victorian novel's avoidance of depicting women in the act of eating "functions as a code for the suppression of female sexuality" (Bordo 183). A delicate appetite was linked with "femininity and with virginity" so that an appropriately sexed woman eats little and delicately (Michie 1987 16-17). According to Lillian Craton, the middle class of the time felt an unhealthy discomfort with 
female physical appetites and linked an appetite for food with sexual desire.

Therefore, they correlated self-control and self-abnegation with respectability. Thus, a woman's character is measured by the size and shape of her waist and also, by extension, her tolerance for hunger and constrictive pressure, from corsets. Among fundamental values of Victorian norms for women, Anna Silver lists "an understanding of the body as an entity that must be subordinated to the will and disciplined as an emblem of one's own self-control," along with a resulting "aesthetic validation of the slender female form as the physical ideal of beauty and a concomitant fear of fat as ugly and/or unfeminine" (qtd in Craton 2009 110). A corpulent individual is, therefore, based purely on an assessment of their physical appearance, assumed to possess certain inner characteristics such as "reckless excess, prodigality, indulgence, lack of restraint, violation of order and space, [and the] transgression of boundary" (LeBesco and Brazil 3). The identity that the corpulent person is supposed to possess-weak-willed and out of control-is attributed to the fat individual simply on the grounds of that person having a fat body.

\section{Persuasion}

In this section I turn to Persuasion, Jane Austen's final completed novel. Jane Austen (1775-1817) completed the manuscript for Persuasion in 1816, the year before her death, and it was published posthumously, along with Northanger Abbey, in late 1817. In Persuasion, through the comic grotesque character of Mrs. 
Musgrove, Austen complicates the tropes surrounding the comic grotesque female character. I also analyze the potential of this character to challenge the status quo.

The corpulent Mrs. Musgrove is the mother-in-law of Anne Elliot's younger sister Mary Elliot Musgrove. The reader first becomes acquainted with Mrs. Musgrove during Anne Eliot's extended visit to her sister Mary. Mary Musgrove and her husband Charles live in close proximity to his parents and his siblings at Uppercross, the Musgrove family estate. Anne has visited frequently in the past and has a warm and friendly relationship with Mrs. Musgrove, Charles' mother. Mrs. Musgrove confides in Anne, mostly about Mary's deficiencies as a mother, and treats Anne as one of the family. Because of this close relationship with Anne, the main protagonist of the novel, the reader is encourage to adopt a sympathetic attitude toward Mrs. Musgrove.

Mrs. Musgrove, however, is noticeably overweight and this quality is frequently stressed by the narrator. For example, Mrs. Musgrove is described as having a "comfortable substantial size" and a "large bulky figure" (101). Similarly, when she mourns her son Dick's death, she expresses herself with "large fat sighings" (101). Her corpulent figure is also emphasized by comparisons with smaller sized bodies. The Musgrove daughters as well as Anne Elliot herself provide this contrast with Mrs. Musgrove. During one scene, when Anne and Mrs. Musgrove share a sofa with Captain Wentworth, the narrator references Anne's "slender form" (101). A little later in the novel, Mrs. Croft refers to Anne's slimness when she offers her a ride in 
the Croft carriage, remarking, "if we were all like you, I believe we might sit four" (in the carriage with Admiral and Mrs. Croft). ${ }^{17}$

Mrs. Musgrove's intelligence and worldly knowledge is often mocked by the narrator. For example, although her son was in the navy, she seems clueless about geography. While describing her own travels Mrs. Croft explains, "we do not call Bermuda or Bahama, you know, the West Indies" (103). The narrator then remarks, "Mrs. Musgrove had not a word to say in dissent; she could not accuse herself of having ever called them anything in the whole course of her life" (103). Similarly, when Mrs. Croft discusses the difficulty of her separation from the admiral during war times, Mrs. Musgrove disproportionately compares the Croft separation to her husband's absence when at the Assizes (104). Lack of intelligence is a trait frequently ascribed to overweight individuals. Anne Brumley, for example, traces this theme in literature from Ben Jonson, who associated fat with second-rate intelligence, to the present time. Mrs. Musgrove's ignorance confirms this association.

Mrs. Musgrove and Anne Elliot have a warm and mutually beneficial relationship. Mrs. Musgrove immediately welcomes Anne as a member of the family at Uppercross and, somewhat to Anne's dismay, confides in her about the family difficulties created by Anne's sister Mary. Anne admires and perhaps even envies, Mrs. Musgrove's excellent and informal relationship with her daughters which is in stark contrast to her own uneasy relationship with her father and older sister Elizabeth. When, late in the novel, Anne hears the Musgroves have accepted their

\footnotetext{
${ }^{17}$ Anne Eliot with her small body and delicate health seems to epitomize the nineteenth-century female ideal discussed by Michie.
} 
daughters' proposed marriages, even though these marriages are not particularly advantageous, Anne thinks, "they do everything to confer happiness...seem so totally free from all those ambitious feelings which have led to so much misconduct and misery" (230). Their lack of ambition, of course, contrasts significantly with Sir Walter Eliot's attitude toward Captain Wentworth's suitability for Anne seven years earlier. When Anne's father and sister call on the Musgrove's in Bath, Anne also notes their "heartless elegance" in contrast to the "the comfort, the freedom, the gaiety of the room" while she is alone with the Musgrove family (236). Mrs. Musgrove and Anne's friendship grows during the course of the novel mostly because of Anne's assistance after Louisa Musgrove's accident. The narrator reports, “Mrs. Musgrove's real affection had been won by [Anne's] usefulness when they were in distress. It was a heartiness, and a warmth, and a sincerity which Anne delighted in the more, from the sad want of such blessings at home" (235).

Although the overweight body, as we will see, is often associated with the lower classes, slim Anne Elliot and large Mrs. Musgrove are of the same class. Nevertheless, Anne perceives, even takes pride in, differences in refinement between herself and the Musgroves. The narrator refers to Anne's "nice tone" of mind and "the fastidiousness of her taste" (67). Mr. and Mrs. Musgrove, on the other hand, are "a very good sort of people; friendly and hospitable, [but] not much educated and not at all elegant" (78). While Anne admires and even envies their happy family situation and the affection between the Musgrove sisters, she feels a sense of superiority, a preference for her own "more elegant and cultivated mind" over the Musgrove 
family enjoyments (78). Anne also feels pride in her more advanced musical skills as she plays the piano a great deal better than either Musgrove sister. Her Musgrove listeners, however, do not have the discernment to realize this fact. Although Mrs. Musgrove's largeness is not linked with a lower class status, it is associated with a lack of refinement and taste.

Mrs. Musgrove's grotesqueness and the significance of that grotesqueness become quite apparent when she speaks of her deceased son to Captain Wentworth who for six months had Dick Musgrove under his command. I quote the narrator's description of Dick in detail as a significant example of the narrator's opinion of Mrs. Musgrove and her grief. According the narrator:

The real circumstances of this pathetic piece of family history were that the Musgroves had had the ill fortune of a very troublesome, hopeless son; and the good fortune to lose him before he reached his twentieth year; that he had been sent to sea, because he was stupid and unmanageable on shore; that he had been very little cared for at any time by his family, though quite as much as he deserved; seldom heard of, and scarcely at all regretted, when the intelligence of his death abroad had worked its way to Uppercross, two years before...though his sisters call[ed] him "poor Richard," [he] been nothing better than a thick-headed, unfeeling unprofitable Dick Musgrove, who had never done anything to entitle himself to more than the abbreviation of his name, living or dead (86). 
Emily Auerbach correctly points to the narrator's attack on the "pretense and blindness" in her "description of the Musgrove parent's denial of the shortcomings of the feckless son they lost at sea" (257). Austen, Auerbach suggests, proposes that "early death may be one way of removing an incorrigible troublemaker and allowing relieved relatives to construct a false but pleasing memory of the dearly departed" (257). As this scene continues, the narrator not only mocks Dick Musgrove's memory and Mrs. Musgrove's grief, but also questions the appropriateness of a fat woman's sorrow. Fat women, the narrator suggests, are made for cheer, not for tears, a reflection of the link between laughter and corpulence.

Initially, Mrs. Musgrove looks to Anne for sympathy and predicts Dick would have matched Wentworth's achievements if only he had lived. Anne suppresses a smile at this prediction but then listens kindly while Mrs. Musgrove relieved her heart a little more" (97). Shortly thereafter, Mrs. Musgrove draws Captain Wentworth aside to discuss her son. Anne, but not Mrs. Musgrove, perceives from his look of "selfamusement" that Wentworth does not share Mrs. Musgrove's wish that Dick had remained under his care (100). He sits with Mrs. Musgrove (with Anne sharing the sofa on her other side and somewhat crushed by her size) and speaks to her with sympathy showing "the kindest consideration for all that was real and unabsurd in the parent's feelings" (101). The implication here, of course, is that some of this parent's feelings are unreal and absurd. The narrator, and Anne to some extent, poke fun at Mrs. Musgrove's grief. Next, the narrator mocks Mrs. Musgrove's physical size. 
On the shared sofa, Anne and Wentworth are divided only by Mrs. Musgrove, but "it was no insignificant barrier indeed" (101). As I discussed above, Mrs. Musgrove is "of a comfortable substantial size" in comparison to Anne's "slender form" (101). Further, Captain Wentworth should receive "credit for the self-command" to keep himself from laughter at Mrs. Musgrove's "large, fat sighings over the destiny of a son, whom alive nobody had cared for" (101 emphasis mine). The novel mocks her grief because of her son's worthlessness and also links her obesity to her sorrowher sighs are large and fat. Although here she expresses deep sorrow, Mrs.

Musgrove, we are told, is "infinitely more fitted by nature to express good cheer and good humour, than tenderness and sentiment" (101). So, not only are her feelings mocked, but they are also somehow illegitimized by nature-perhaps a reminder that fat individuals are linked with laughter, not with sorrow.

After ridiculing her sadness, the narrator then philosophizes on how, "Personal size and mental sorrow have certainly no necessary proportion. A large bulky figure has as good a right to be in deep affliction, as the most graceful set of limbs in the world. But, fair or not fair, there are unbecoming conjunctions, which reason will patronize in vain, --which taste cannot tolerate, --which ridicule will seize" (101). According to Auerbach, the narrator "reminds us that the stereotype of fat older women as butts of humor-including the amusement she provides through Mrs. Musgrove-wrongs the Mrs. Musgroves of real life" (259). Further, Auerbach argues, Austen employs her "artistic powers to shatter illusion and reflect the reality she sees" (259). In this scene, Austen certainly pulls a fast one on her readers. She first 
encourages the reader to laugh at Mrs. Musgrove because of the combination of her affliction and her large proportions and then almost immediately critiques this laughter. She points out the double standard applied to the obese where they are not "allowed" to indulge in certain emotions.

The fat body is, of course, strongly associated with laughter. The fat individual, because of their disproportionate body, is the subject of superior laughter. According to Andrew Stott, the excessive, ill-disciplined, and profane body is a standard comedic prop (86). Stott also argues that this laughter requires an understanding of the "socially acceptable body" that, through its distortion, enables laughter (86). The socially acceptable body has, as we have seen, come about through a variety of medical, scientific and cultural discourses in the nineteenth century. Stott defines the laughter surrounding the fat body with Freud's superiority theory of laughter as it "operates in the absence of a joke and focuses on physical defects, personal misfortunes, and social inequality" (135). According to this theory, people laugh when they encounter a person or situation in which they feel intellectually, morally, or physically superior (132). Stott also links this laughter with the incongruity theory of laughter which describes laughter as arising from the unexpected. The incongruous occurs when a body highlights the social norms and expectations related to body size by violating them. This transgression of social and cultural values makes us laugh. Mrs. Musgrove's size renders her the object of both superior and incongruous laughter. 
According to Angela Stukator, overweight women are more frequently the objects of laughter than are overweight men. She explains that while "the laughter the fat woman evokes may or may not be bound to her wit, a narrative gag, or prank, it invariably pertains to her physical body" (201). Further, Stukator points out that large and, especially, "audacious women are often constructed as comic spectacles" (197). A large woman can therefore become the target of our laughter based both on her appearance and on her behavior. A corpulent woman, however, who makes a spectacle of herself through her appearance and actions, can be more than a source of amusement; she is also a potentially subversive force.

In the novel's exploration of the fat grotesque female, Persuasion illuminates and then challenges the assumptions surrounding the grotesque female. By mocking the reader's stereotypical reaction to the female grotesque body, the novel suggests a possibility of disrupting accepted notions and prejudices surrounding the fat female body. Mrs. Musgrove is far from a subversive character; she is extremely likeable and does not herself challenge societal norms. Nevertheless, through her character, the novel challenges normative assumptions surrounding the identity of the corpulent individual, especially the corpulent female.

\section{The Semi-Detached House}

In this section, I analyze Mrs. Hopkinson, an overweight, comic grotesque female character, who appears in Emily Eden's novel The Semi-Detached House. The corpulent and comic Mrs. Hopkinson, like Mrs. Musgrove, challenges our assumptions surrounding the nature and risibility of comic grotesque characters. The 
middle-class Mrs. Hopkinson, however, also demonstrates the potential of the comic grotesque to challenge class hierarchies and societal norms by associating on equal terms with her aristocratic neighbors.

Emily Eden (1797-1869), author of The Semi-Detached House (1859), was the daughter of William Eden, first Baron of Auckland, an influential politician and diplomat. After her parents' deaths in the late 1810s, Eden moved from the family's country estate in Kent to London to live with her brother George, second Lord Auckland, a Whig politician and cabinet minister. In London, she became, as her brother's hostess and political advisor, an active participant in political and aristocratic circles. Eden refused all marriage proposals, most notably one from Lord Melbourne, preferring what she called "a life of single blessedness" to the isolation and grief she observed in the "splendid marriages" of her contemporaries (Fellows 108). When her brother was appointed Governor General of India in 1835, Eden travelled to India with him as his hostess and First Lady. After her return from India Eden published several volumes of her letters from India which were quite popular among her contemporaries. She wrote just two novels The Semi-Detached House in 1859 and The Semi-Attached Couple in 1839 (published in 1860). Her reputation as a novelist is principally as a Jane Austen substitute--a "mid-Victorian rival to Jane Austen" (Plotz 163). She certainly paid homage to Austen through specific references to Austen's novels and her creation of similar plotlines and characters. But, while the society in Austen's novels consists of a mix of middle-class and the country-gentry 
characters, Eden writes of the society she knew best - the elite social circles of Whig aristocrats.

As the novel opens, the eighteen-year old aristocrat Blanche, Lady Chester, takes up residence in a semi-detached house, called Pleasance, in the suburban village of the appropriately named Dulham. Her husband Arthur, Lord Chester and heir to Earl Chesterton, is about to leave on a three-month diplomatic mission to Berlin. The young couple, who are "foolishly in love," have only been married for six months and dread their parting. Blanche, always in delicate health, is now in a delicate condition as she is pregnant with their first child. Arthur selects a house in the suburbs as the best housing option, because her doctor wishes her to be out of unhealthy London during her husband's absence yet "within reach of [his] surveillance" (19). Blanche's unmarried sister Aileen stays with her at Pleasance. The middle-class Hopkinson family live in the small house at the back of Chester's house. With Captain Hopkinson away at sea, the family at home consists of the middle-aged Mrs. Hopkinson, her two twenty-something daughters, and her grandson, the child of a deceased eldest daughter. The novel explores the initial misunderstandings and the subsequent friendship between the aristocratic and middle-class residents of the semi-detached house.

When first hearing about the semi-detached house and before viewing it or meeting the neighbors, Blanche amusingly makes a prediction about the habits and appearance of her new, middle-class, suburban neighbors. She declares, "I should hate my semi-detachment, or whatever the occupants of the other half of the house 
may call themselves" (15). She jokes about the appearance of her new neighbor saying, she will surely be "immensely fat, wear mittens-thick, heavy mittens-and contrive to know what I have for dinner every day" (15). Upon discovering the mother has two daughters and a little boy, she predicts that the girls will always be playing Partant pour la Syrie, a French military song, and the little boy will "always be throwing stones" and "making me jump" (14). She clearly expects her new neighbors to display vulgar markers of their lower class origins.

Blanche's prediction, in many ways, is quite accurate. Mrs. Hopkinson is fat, wears mittens and, through her own servants, knows what's happening in Blanche's household. The girls are quite musical, singing and playing the piano, though they do not repeatedly play French military songs. On the other hand, the little boy, Charlie Willis, is sickly and frail so does not throw stones or create loud noises. The central irony of the novel is that, despite the truth of these predictions and their differences in class, Blanche and her sister become great friends with the Hopkinson's. Mrs. Hopkinson may be overweight and gloveless but she is also unencroaching and eventually very nurturing toward Blanche. Her knowledge of Blanche's household is quite helpful when the kitchen flue breaks and fills Pleasance with smoke, driving Blanche and Aileen out into the pouring rain. Mrs. Hopkinson instructs the servants on how to fix the problem and welcomes the sisters into her own home to recover over tea. Further, the musical daughters, Janet and Rose Hopkinson, in order to avoid disturbing Blanche with their piano playing have moved the piano into a back room. In fact, Janet and Rose prove to be highly talented singers who charm Blanche and 
her aristocratic visitors with their voices and song selections. They are frequently invited to visit and are treated as friends rather than as mere performers.

The friendship between the Chester and Hopkinson families is at first blocked by the class prejudices felt by both parties, as I discuss below. Once they move beyond these prejudices, they form a mutually beneficial relationship. Mrs. Hopkinson has the practical knowledge that Blanche and her sister lack. Early in the novel she solves their problem with the kitchen flue but she provides more significant assistance late in the novel by acting as a midwife when Blanche goes into labor unexpectedly. Because she includes the Hopkinson daughters in her social engagements, Blanche introduces Rose to her future husband, a friend of Arthur's. In addition, Blanche arranges, through her father-in-law, a more advantageous clerical position for the local curate, coincidently another of Arthur's friends, so that the curate can now marry Janet Hopkinson. Blanche also arranges medical care for the frail Charlie Willis which helps relieve his suffering. Finally, after his return from Berlin, Arthur arranges for Captain Hopkinson to assume the well-paid position of “Duke's Agent for the Pier and Harbour of Seaview" (253). As Monica Cohen states, the "novel quickly turns into a recounting of the romance these aristocrats have" with the middle-class Hopkinsons (38). The important question is how long does this romance last? How long does Mrs. Hopkinson stand on equal terms with the aristocratic Blanche?

The reader's, as well as Blanche's, first view of Mrs. Hopkinson is as a woman of "large dimensions" who "feel[s] the heat of the weather dreadfully" (32-3). When she shares the Pleasance pew with Blanche and Aileen, Blanche experiences "the heat of 
the poor woman...it was like having a stove put in the pew" (33). Mrs. Hopkinson also sweats excessively. Through the narrator and the characters in the novel, Emily Eden repeatedly underscores Mrs. Hopkinson's transgressive body. For example, besides the initial reference to her large dimensions, Aileen refers to her as Blanche's fat friend (35); she has "fat arms" (57) and "fat hands" (61); a "portly figure" (56); and a pair of feet that left large impressions on the soaked gravel (56). Mrs. Hopkinson refers to herself as fat (173), a vulgar old woman (174) and "looking like a respectable housekeeper" (112) rather than a middle-class wife. In contrast, Aileen describes Mrs. Hopkinson's daughters as slim, nice-looking girls (35-6). Mrs. Hopkinson's black mittens are also ubiquitous, receiving almost as many references as her corpulent body.

Mrs. Hopkinson is the quintessential Bakhtinian grotesque by virtue of her overweight body. Bakhtin, as I explained in Chapter One, emphasizes the mouth and the belly in his definition of the grotesque. Further, eating and drinking are among the "main events in the life of the grotesque body" (Bakhtin 317). Through her exudation of a furnace-like heat and her sweating, Mrs. Hopkinson's body is porous with blurry boundaries, evocative of Bakhtin's description of the grotesque body. Her behavior and habits also align with both Mary Russo's and Kathleen Rowe's descriptions of how unruly women create spectacles of themselves. Nervous at sharing a church pew with her aristocratic neighbors, Mrs. Hopkinson is "puffing and blowing" as well as sweating during the service (35). After their first meeting, Blanche calls her "perturbed in mind and very uncomfortable in body" (35). And, of course, 
she wears her black mittens constantly as well as "very short petticoats" (56). Her appearance and her behavior, especially when nervous, qualify her as an unruly woman. Kathleen Rowe describes the unruly woman as a "topos of female outrageousness and transgression from literary and social history" (82). This topos, she theorizes, reverberates whenever women, especially women's bodies, are considered excessive (including too fat) for "the norms of conventional gender representations" (82). The unruly woman can operate either to "reinforce traditional structures" or to "help sanction political disobedience" (83). Mrs. Hopkinson certainly has the excessive body of the unruly woman. I will discuss below whether she challenges the status quo and how successfully she is able to do this.

Mrs. Hopkinson has excellent practical knowledge surrounding household matters such as kitchen flues and midwifery. Her son-in-law has "a great opinion of her sterling sense" in relation to her instincts about a new acquaintance's character (113). Despite this, the text suggests her intelligence in other ways is quite limited. For example, she lacks knowledge of politics and geography. Mrs. Hopkinson, the narrator reports, "always read the Court Circular and the Police Reports. The rest of the paper was beyond her powers" (44). When her son-in-law chides her for not reading more fully, she replies that he might as "well ask me to read a list of Red Morocco Chiefs. She fancied that the Moroccan population was bright scarlet" (24). Her ignorance is clearly similar to that of Mrs. Musgrove. When asked if her new mantilla, a gift from her husband, came from Spain, she responds, "It came from Funchal, though where that is, I can't say" (180). Because her husband is a sea 
captain, it is surprising that Mrs. Hopkinson should know so little about geography. Mrs. Hopkinson calls to herself as "stupid as an old post" (82). As we have already seen, low intelligence is often correlated with corpulence. When a viewer or reader encounters an overweight person, he/she assumes the person has less intellectual ability than the norm. Mrs. Hopkinson's lack of understanding around worldly matters would appear to confirm this theory.

By comparing Eden's treatment of another corpulent body, that of Captain Hopkinson, we can see not only how the novel focuses relentlessly on Mrs. Hopkinson's fat body, but also the dichotomy in how corpulence is treated in females vs. males. Initially, Mrs. Hopkinson refers to her husband as a "stout, florid man with blue eyes and a round face" (66). When he returns from his sea voyage, the narrator states, he is "tall, erect, fresh coloured, his crisp dark curls clustering over his manly looking head, and his keen blue eyes full of intelligence" (168). A little later, he is referred to as a "fine looking man" (177). Neither of the 'in person' descriptions of him mention his excessive weight. The novel's discourse surrounding their bodies confirms a different aesthetic standard for male and female corpulent bodies. Interestingly, we also see differences in their behavior, especially class-related behavior. Although Mrs. Hopkinson refers to herself as a vulgar old woman, her husband, on the other hand, "amalgamates well with Lord Chesterton" (178), a proud Earl, and has a "frank gentlemanlike manner" (253). Captain Hopkinson with his gentlemanly demeanor and fine, manly appearance is comfortable with his 
aristocrat neighbors while the corpulent Mrs. Hopkinson is uncomfortably (and continuously) aware of her lower-class status.

The ideal female body is sharply contrasted with the acceptable and admired male body of the nineteenth century. Bordo points to the "sharp cultural contrast" between the female and the male form which symbolized the division of social and economic life into clearly defined male and female spheres (181). In the middle class, for example, a woman's frail frame and lack of appetite signified not only a spiritual transcendence of the desires of the flesh but social transcendence of the laboring, striving "economic" body (Bordo 117). Women, as represented through their bodies, portrayed their middle-class status by an aristocratic lack of concern with "material desires" (Bordo 117). A man, on the other hand, was not required to exert an equal self-control over his appetite ${ }^{18}$. A protruding male stomach could indicate bourgeois success (Bordo 117). This image has partly encouraged the misconception that excess weight was not an issue for the Victorians. A middle-class man's excess weight reflected his wealth, contrasting him with the deprivations of the working-class body. Conversely, his slim wife with her ethereal body was a status symbol for the middleclass male as her body reflected his aristocratic tastes

Class is also an important factor as demonstrated by Mrs. Hopkinson's assistance in the birth of Blanche's child. With her doctor away and the hired nurse not yet in the house, Blanche is "taken ill," i.e. goes into labor, earlier than predicted. The newly-returned and panicked Arthur wakes Mrs. Hopkinson in the middle of the

\footnotetext{
${ }^{18}$ On the other hand, Huff's article on William Banting's diet method does demonstrate that at least some nineteenth-century men were unhappy about their excess weight.
} 
night, calling on her "experience as a mother and a nurse" (191). Mrs. Hopkinson, amusingly thrilled to be awakened, declares herself as "good a month nurse as any in the kingdom" and successfully delivers the Chesters' baby son (191). Mrs.

Hopkinson's skill as a midwife and nurse clearly supersedes that of the inexperienced replacement doctor who occupies his time telling Arthur "horrible surgical anecdote[s]" (195). Arthur and Blanche both view Mrs. Hopkinson as a life-saver and give her credit for the continuity of their aristocratic family. Once the crisis is over, Mrs. Hopkinson continues to care for Blanche and the new baby and Blanche sees Mrs. Hopkinson in her typically dramatic way as a "miracle of wisdom on the subject of babies in general, and this valuable baby in particular" (211). Miss Smith, the nurse, agrees saying, "that good lady knew very well what she was about, and that, considering how delicate Lady Chester was, and how little she knew about a nursery, it was quite a mercy she had Mrs. Hopkinson to look after her" (211). As Sarah Bilston accurately observes, the "upper class characters seem barely able to function in the face of a genuine, if every day, crisis" without the practical help of their middle-class neighbor (635). Blanche relies totally on Mrs. Hopkinson's experience in the care of her new baby.

Mrs. Hopkinson's midwifery role, in addition to her corpulent body, link her to Bakhtin's definition of the grotesque. Childbirth, of course, is related to the lower bodily stratum of the grotesque. Birth is part of the "collective, growing and continually renewing body of the people" (Bakhtin 23). Similarly, Grotesque Realism represents a concern with the life of the "belly and reproductive organs; [it] relates 
to acts...of conception, pregnancy and birth" (23). Oddly enough, as I discuss later, although her condition qualifies for the lower bodily stratum, the pregnant Blanche is a less grotesque character than Mrs. Hopkinson. Eden's descriptions of her, in fact, suggest exactly the opposite.

Mrs. Hopkinson's skill in nursing Blanche and the new baby also links her with one of the tropes of fatness--an increased ability to nurture. Through her analysis of Clara Peggotty in David Copperfield and Mrs. Jarley in The Old Curiosity Shop, Lillian Craton argues that overweight, lower class characters are better mother figures than higher class, delicate ladies. She posits, "Female Fatness, as a sign of plentitude and inexhaustible reserves of nurturance" as opposed to the lack of energy and thus the ability to nurture displayed by the slimmer body of the cultural ideal (292). Peggotty's fatness, for example, implies reserves of strength and energy and by extension suggests that the excessive output expected from Victorian mothers can best be met through an equally excessive intake (302). Craton argues that, through the contrast they provide with the novels' leaner characters, these fat ladies provide an "important alternative image of the nurturing ideal for Victorian womanhood" (299). Mrs. Musgrove in Persuasion and Mrs. Hopkinson in The Semi-Detached House are both represented as mother figures and nurturers, though with varying success. Mrs. Hopkinson, for example, cares for her neighbor's newborn baby with a skill lacking in the ethereal new mother. On the other hand, she lacks insight into the need for medical care essential to her grandson's very survival. 
The narrator and the other characters refer to Blanche's delicate state of health repeatedly. At the time, of course, a delicate state was often a euphemism for pregnancy, but the term "delicate" in this novel also references Blanche's lifelong fragility. In fact, at one point she is described as "fragile and pretty" (60). Blanche, we are told, has been delicate "at all times" throughout her life, so that she follows her family doctor's advice "implicitly" (19). Similarly, her aunt Sarah states she looks "too ethereal for contact with the vulgar ills of life (16). As I discuss in more detail below, Ehrenreich and English theorize that the physical frailty of an affluent woman rendered her "most delicate and most in need of medical attention" (Michie 1987 30). Blanche seems the epitomy of the frail, upper-class woman.

Blanche's high-strung personality, the highs and lows of her spirited nature, also affects her health. She indulges in endless fantasies about her poor health and the possibility of her husband's love diminishing. When Arthur first leaves for Berlin, she cries so excessively that her doctor has to scold her for threatening her health. Later, she imagines she may die from a sore throat. As the narrator states, "she was one of those excitable people whose health fades when their spirits are depressed, and who expand into strength when their minds are at ease" (48). Her Aunt Sarah pronounces, "it is a great pity she is so imaginative and so fastidious" (15). This ethereal, highlystrung woman is far more associated with the mind and her imagination than with the material body of Bakhtin's grotesque.

On the surface, Mrs. Hopkinson and Blanche are the targets of the readers' laughter. Eden encourages us to mock Mrs. Hopkinson's black mittens and lack of 
intelligence as well as Blanche's flights of fancy. The laughter in this novel, however, is more complex than simply employing superior humor. First, both women find humor in their own idiosyncrasies. Mrs. Hopkinson laughs at her fatness and the Captain's remarks on her fatness during the scene when she declares she is too fat for a dinner party. Mrs. Hopkinson also displays the awareness that her black mittens are not fashionable enough for upper-class company; the other reason she cannot attend the Chesters' dinner is her lack of decent gloves. Similarly, when her aunt describes her dramatic tendencies and lists all her fantasies, Blanche admits, "when you say all her fancies together, they are amusing" (16). Because these characters are able to laugh at themselves, we as readers are encouraged to laugh both at and with them. Additionally, these characters and their idiosyncrasies are viewed sympathetically by the narrator and the other characters. Therefore, the reader views them as sympathetic as well. We are meant to like them, not merely view them as figures of fun.

Similarly, Bakhtin's description of carnival laughter evokes a more complex laughter than one of derision. According to Bakhtin, festive laughter is universal in terms of its responsiveness to the gaiety of the entire occasion, rather than being directed at a specific object or isolated comic event. Further, carnival laughter is not egotistical or superior; it does not conform to the comic theory of superiority. Similarly, the humor of The Semi-Detached House does not depend solely on designating characters as the object of mockery. The reader instead is encouraged to 
find humor in the characters' own amusement around their foibles; foibles that readers may experience themselves.

Class and class prejudice have a prominent role throughout The Semi-Detached House. According to Judith Plotz, the novel "enacts a set of Pride and Prejudice style reversals" (181). Pride emerges from the aristocratic Blanche Chester's "assumption of middle-class Hopkinson vulgarity" while Prejudice arises from the Mrs. Hopkinsons' "self-righteous expectation of aristocratic vice" (181). Certainly, as I discussed earlier, Blanche, described as "easily jarred by the slightest want of refinement" and "too ethereal for contact with the vulgar ills of life," holds preconceived (negative) notions concerning her lower-class neighbors (Eden 16). Among her assumptions about her new neighbor is the link between a lower-class individual and fat which is a common conjecture.

Similarly, Mrs. Hopkinson, privy to a rumor of aristocratic decadence that "Lord Chester's going to establish his mistress next door," is prejudiced against upper class immorality (29). Mrs. Hopkinson, of course, eventually learns that the rumor is false and also realizes that aristocracy is not the "repository of vice she suspects" (O'Cinnedie 60). She observes, for example, the Chesters' desire to interest themselves in the needy families in the town of Dulham. On finding out that the Duchess of St. Maur, Blanche's friend and relative, spoke about patients at the Convalescent Hospital, Mrs. Hopkinson states, "I suppose the aristocracy are not so bad as we are told...They seem to do a kind thing now and then" (45). The eventual 
friendship unsettles the "normative class hierarchy" of the nineteenth century (Bilston 635).

One of the most prevalent encoded meanings of fatness is its association with the lower classes. Pat Rogers traces the use of the body as a marker of status in literature through his example of the lean master, Quixote, and full-bellied servant, Sancho, in Cervantes' Don Quixote. Rogers also traces changes in corporeal codes from the eighteenth to nineteenth-century novels. In eighteenth-century literature, a large or corpulent body was often an "emblem of [high] social position or blooming health" (32). During the nineteenth century, however, thinness began to be associated with the upper classes while servants, and others of lower status, are represented as short and corpulent. According to Susan Bordo. the "gracefully slender body announced aristocratic status; disdainful of the bourgeois need to display wealth and power ostentatiously, it commanded social space invisibly rather than aggressively, seemingly above the commerce in appetite or the need to eat" (191). Subsequently, as the middle class rises in power and status throughout the nineteenth century, middle-class ladies begin to appropriate this ideal, as slender wives became the showpieces of their husbands' success. A slim wife could serve to augment male status at the same time the husband's large belly demonstrated his success. A narrow waist, therefore, reflected on a woman's social status as well as on her personal character. The tighter she could draw her laces and, thus, the smaller her waist, the more her body illustrated a privileged social position (Craton 2008 294). Working class bodies, on the other hand, were imagined as robust so they were able to 
perform the physical work not expected of an aristocratic or middle-class lady. The middle-class lady, anxious to display and maintain her rank, used "bodily control as a status symbol" (Craton 2008 294).

Self-abnegation, therefore, is a marker of a higher status female. Helena Michie argues, a “woman's femininity and her social position are defined quite literally by negation; the denial of hunger is an affirmation of a precarious class position" (1987 18). Conduct books written for upper and middle-class readers affirmed the moral aspects of self-denial of physical appetites. Michie also views Victorian novels as "reflecting the class component of the formula" equating delicate appetites and ladyhood (26). Barbara Ehrenreich and Diedre English point out "the medical profession as a whole...maintained that it was affluent women who were most delicate and most in need of medical attention. Her physical frailty went hand-inwhite-gloved-hand with her modesty, refinement and sensitivity" (qtd in Michie 30). Michie points out how the delicate upper-class women had to be protected from and nursed through the "sexual storms" of menstruation, pregnancy and menopause (31). Working class women, on the other hand, were robust just as they were supposedly coarse and immodest. We see this dichotomy in the lower-class Mrs. Hopkinson's midwifery services and nursing care of the upper-class, delicate Lady Chester through her childbirth.

Class, of course, is also an essential component of Bakhtin's theory of the grotesque in carnival. The classical body, represented as impermeable, perfect and whole, without orifices or openings, corresponds to the aristocratic body. The 
grotesque body, represented as porous with blurry boundaries, focused on the lower portions - the buttocks and genitals-- and on other orifices such as the gaping mouth, corresponds to the working class. Michie views the bourgeois body, the body of the middle-class subject, as based on the classical standards of the aristocratic body. The Victorians, she claims, "inherited and...perfected this notion of the bourgeois body with its roots in classical aesthetics" (1991 408). Their ideal of the bourgeois body was one that was closed off and separate from the bodies of others. Jane Arthur traces the change from medieval to modern society which lead to class distinctions. As the "regulation of bodily habits" became more widespread, the culture of the people "with their spontaneous bodily drives" was progressively marginalized and condemned by the emerging middle class (408). The corporeal humor of carnival became associated with all that was to be excluded from the polite legitimate culture of the middle class and increasingly linked with the lower classes. This link with class is readily apparent in my exploration of The Semi-Detached House.

Mrs. Hopkinson's lack of social status is emphasized by the contrast with her more refined, better educated daughters. Although she resists attending any of Blanche's parties, saying she "doesn't want to turn into a fine lady," she does, however, comment that her daughters "would make a nice job at being like" Lady Chester and her sister Aileen (65). She is quite happy at her daughters' inclusion at aristocratic parties and, of course, their eventual marriages to men of a higher class. Although Janet and Rose are admired for their musical talents, they are also welcomed among the Chester's circle because of their unaffected nature and good humor. They, unlike 
the Sampsons (see below), are not encroaching or vulgar. For example, the narrator states they are invited to many of the parties at Pleasance, "not for their musical talents, but for their own amusement, and they were so unaffected and so merry that they became general favorites" (141). Similarly, the Duchess of St. Maur, more accustomed to aristocratic debutantes in London, refers to Janet as a "quiet unaffected girl [who] is quite refreshing" (99).

Within this novel's focus on class concerns, the social-climbing Baron and Baroness Sampson provide an interesting subplot. Their "high noses" and "jet black hair" as well as their overly-lavish entertainments identify them as Jewish (40). And, despite the middle-class Hopkinsons mixing on equal terms with the Chesters, the Sampsons are never welcomed into the Chester's society. Judith Plotz suggests the Sampsons are "unassimilable" by biological destiny (182). The Sampsons, Plotz continues, "play up their Englishness by aping the vices of English philistines: snobbery and hypocrisy" (182). I analyze their snobbery as it provides an interesting view of the Chester's and the Hopkinson's relationship to class and class mobility.

Baroness Sampson constantly talks down to Mrs. Hopkinson in an attempt to establish her ostensibly higher-class status over her. She calls the Hopkinson's home a "dear, tidy little cottage" but it wouldn't be big enough for her own family's needs (68). She enlists Mrs. Hopkinson's help in searching for a house in Dulham but at the end of the day requests she "find her way home on foot" (74). Mrs. Hopkinson, in an amusing contrast to her own self-expressed vulgarity, thinks the Baroness is "very vulgar" (74). After the Baroness moves into her new residence, she cannot efficiently 
manage her servants and asks Mrs. Hopkinson to act as a quasi-housekeeper by firing servants and managing the inventory. This request, however, "was too much even for the good nature of Mrs. Hopkinson, who was, according to the narrator, as "nearly being angry as ever she was in her life" (105). Mrs. Hopkinson reflects that the Baroness perhaps thinks of her as lower status because, "I suppose I look like a respectable housekeeper, and she thinks I am one" (112). Further, she cannot quite categorize the Sampsons" class status saying "I do not quite make out what they are...Very fine, my dear, but not a lady" (112). She regards the Baroness' "helplessness, her ignorance, [and] her nerves [as] all pretence" (112). She refuses to allow Baroness Sampson to treat her as a drudge but the Baroness continues to think of Mrs. Hopkinson as "poor, dear, vulgar Mrs. Hop" just as Mrs. Hopkinson refers to the Baroness as vulgar (123).

The aristocratic characters differentiate quite clearly between the Sampson and the Hopkinson families. When the Baroness Sampson calls on Mrs. Hopkinson while Blanche is visiting, Blanche asks Mrs. Hopkinson to avoid mentioning her name (she makes this request before the Baroness enters the room; she does not snub her directly). Similarly, Arthur resists their company and criticizes the vulgarity of the Baron's carriage and the flashiness of his wife. When Rose's intended, Mr. Harcourt, contemplates attending the Sampsons' garden party uninvited, he reflects with snobbery, "they will take our going [to their party] as a compliment. I don't suppose an invitation is necessary; they are just the sort of people to call us 'swells,' and to think it stylish of us to come uninvited" (230). This is an interesting and revealing 
comment in light of his engagement to the middle-class Rose Hopkinson. In the class hierarchy of this novel, the Sampsons are the unwelcome upstarts, while the Hopkinsons, despite Mrs. Hopkinson's self-described vulgarity, are welcomed not just to aristocratic parties but into aristocratic marriages.

The suburban location of this novel holds fascinating implications for class and liminality. Theorists of nineteenth-century suburbs analyze the importance of this new phenomenon in terms of its relationship with both the middle class and with the potential for social mobility. Muireann O'Cinneide terms the suburbs as the "triumph of bourgeois identity" in that they offer a physical realization of the separate spheres ideology, by providing the middle-class male with a private domestic retreat from the public and urban world of work (59). According to Gail Cunningham, the "rapidity and magnitude of suburban growth" in nineteenth-century England served to "efface the clear boundaries" between classes (422). In The Semi-Detached House, we certainly see the mixing of upper and middle-classes due to their proximity in the suburban semi-detached house. Judith Plotz describes this novel as creating a "performative new space, which juxtaposes a rurally-rooted equestrian Whig aristocracy" with the middle class (181).

As I have already discussed, the aristocratic Blanche is initially unsettled by her new proximity to middle-class neighbors. She fears their noisy and nosey encroachment on her privacy and by implication her status, which up to now has kept her separate from middle-class intrusions. The suburbs, unlike urban and rural environments, allow this intrusion; in this novel, the proximity afforded by the 
suburbs also leads to inter-class friendships and the albeit temporary suspension of class distinctions.

The suburbs by virtue of their position between urban and rural places have no clear boundaries; they can be termed as liminal spaces. Cunningham argues that suburbia is the "third term inserting itself between the traditional cultural binary of country and city" (423). Further, she posits the suburbs have "no clear boundaries, are boundary-less and also potentially boundless" and, in her study, finds that the very boundary-less quality of the suburbs makes it hard to define what, or where, they were (423). The extensive and rapid growth of suburbia in the nineteenth century led to an erosion of the traditional binary, or the clear boundary, between town and country. In this boundary-less space the middle-class Hopkinson and aristocratic Chester families are able, for a time, to suspend class divisions.

In addition to the suspension of class distinctions, the suburban location also lends itself to the potential inversion of gender hierarchies. Several theorists ( $O^{\prime}$ Cinneide, Cunningham, Bilston) have identified the female dominated nature of the suburbs in the nineteenth century. According to O'Cinneide, the whole of the suburban middleclass home is in theory a feminized space (66). Cunningham argues that the daily exodus of men from commuter suburbs to London created a uniquely femaledominated space, not just within the house but across the entire suburban environment (425). Suburbia, T.H. Crosland posits, is given over to the "the unquestioned rule of women" (qtd in Cunningham 21). Cunningham also states that, "the perceived inversion of the gender power base informed many writers' 
conceptions of sexual relations in the suburbs" (426). Certainly, The Semi-Detached House performs this inversion of gender power. Although neither husband in the novel commutes to an urban environment, both are away from home during the majority of the novel-Arthur Chester on a diplomatic mission to Berlin and Captain Hopkinson away at sea. The two wives share a feeling of abandonment; Blanche feels abandoned by her husband during her pregnancy while Mrs. Hopkinson confides that her husband John has left her for more than half of every year since their marriage, including after her confinements (Eden 61). O'Cinneide comments that, in the world of the novel, Blanche Chester, her sister Aileen and the three Hopkinson women "all seem curiously isolated, cut off from the urban world by the bubble of suburbia" (60). This seeming isolation is underlined by the absence of the husbands. Therefore, the woman not only form a connection through their shared residence, but also through their common marital situations. Their connection is strengthened by the revelation that their husbands were acquainted in the past when Captain Hopkinson nursed Arthur through a serious illness. A close friendship blossoms during another female-centered scene: Mrs. Hopkinson acting as midwife for the Chesters' baby son.

This unique friendship, based on their shared residence in suburbia and their female-centered households, results in Blanche explicitly calling her middle-class neighbor her "friend" (233). Because of this friendship, the Hopkinson family are invited to the Chesters' parties and dinners. The Hopkinson daughters attend musical entertainments in London under the escort of the Duchess of St. Maur, Blanche's relative and friend. Blanche also assists the Hopkinson daughters in marrying well, 
both to old friends of Lord Chester. While Janet's husband is a middle-class clergyman with upper-class connections, Rose's husband, Mr. Harcourt, is an aristocrat. The self-described fat and vulgar (grotesque) Mrs. Hopkinson eventually learns to participate equally at the Chester's formal dinners with their aristocratic guests. The relationship between Blanche Chester and Jane Hopkinson leads to an inversion of class, with a relaxing of class divisions. Class inversion is an integral part of Bakhtin's theory of the grotesque in carnival. Through carnival, Bakhtin argues, the people, for a time, enter "the utopian realm of community, freedom, equality and abundance" (9). Bakhtin characterizes carnival as a world where freedom is absolute-all hierarchies and strictures of everyday existence are suspended (Taylor 57-8). Bakhtin also specifically links inversions to the grotesque body in that they create a utopian "counterculture" which gives "recognition and acceptance normally denied" to the body and to peasant life (66). Mrs. Hopkinson certainly gains an acceptance normally denied to one of her class and body type. Unfortunately, her recognition and its utopian nature is, as Bakhtin theorized, only temporary.

As I have already discussed, by the end of the novel, the Hopkinson daughters achieve marriages with higher class gentlemen. The Chesters not only facilitate these marriages but they also assist in the acquisition of a higher position for Captain Hopkinson. Arthur suggests Captain Hopkinson for a job as the Duke of St. Maur's agent for his new harbor at Seaview. One of the vital requirements for the position appears to be the Captain's "intelligence and frank gentleman-like manner" (253). The elder Hopkinsons now have the advantages of a "good house and a handsome 
salary" (253). They, like their daughters, achieve significant material advancement through their relationship with Lord and Lady Chester. Initially, Blanche envisions a different relationship with Mrs. Hopkinson, one which Sarah Bilston calls as "looking dangerously feudal" (636). In praise of Mrs. Hopkinson's care for the Chester newborn, Blanche observes, "I should like her to be near baby, she understands him so thoroughly; and if she would take care of him, I could take care of her," she observes (223). She also wishes that Chesterton Castle, the family estate, was semidetached, so that Mrs. Hopkinson could share it as they have shared the semidetached house in Dulham. Both families, however, leave their 'semi-detachment' with the Hopkinsons moving to Seaview while the Chesters move to the rural, family manor. According to O'Cinneide, Eden is ultimately unconvinced about both the "middle-class power relations" inherent to suburbia and the long-term possibilities of these relations being replaced by those of her "ideal deferential order" (63). Certainly, the Bakhtian utopia of a democratic social order with Blanche Chester and Jane Hopkinson meeting as equals has proved temporary. The Hopkinson's acceptance of the position as the Duke's agent confirms that their relationship with the Chesters and their extended family will be deferential rather than equal. They are the beneficiaries of upper-class bounty and their future friendship will be limited by this fact.

As I discussed in Chapter One, the female grotesque or unruly woman may have a subversive or transgressive potential in literature and in life. The power of the female grotesque and of female laughter can challenge social and symbolic systems that 
keep women in their place. Women who make spectacles of themselves by transgressing norms through their appearance and/or their behavior have the potential to subvert class and gender hierarchies. According to Russo, for example, women can challenge the status quo through the grotesque; she sees power in representations of the female body as grotesque (1994 13). According to Sarah Schieff, Russo's work "permits the reading of literary fat ladies not as abject and selfdestructive victims of their psychology and circumstance but as risk takers and trailblazers who transcend and destabilize the normal" (217). This positive valuation of the grotesque female is also shared by Kathleen Rowe and Joyce Huff.

Kathleen Rowe examines the power of female grotesques and female laughter to challenge the "social and symbolic systems" that work to keep women in their place (1995 3). Like Russo, Rowe defines female spectacle-making when performed by the unruly woman as a "kind of transgressiveness" associated with social and literary traditions of carnival (1995 3). The unruly woman can enjoy a reprieve from fates for women in patriarchal society, because her home is "comedy and the carnivalesque, the realm of inversion and fantasy where, for a time, the ordinary world is topsy turvy" (1995 11). Laughter and inversion, as I discussed in Chapter 1, are vital components of the carnivalesque.

Rowe also emphasizes the significant role of laughter in relieving women's repression from "social and cultural structures" (1995 3). Joyce Huff argues for the possibility of a subversive laughter to challenge the negative representation of corpulence in society. She connects laughter and corpulence as two defining 
characteristics of an alternative, carnivalesque tradition that privileges bodies that defy categories. Further, this alternative tradition can positively "refigure deviance" as a difference to be celebrated (2010 54). Earlier, in my discussion of Mrs.

Hopkinson, I analyzed the complexity of the comedy surrounding this character and its resemblance to carnival laughter.

Rowe argues that the figure of the unruly woman, defined as "too fat, too funny, too noisy, too old [and/or too] rebellious," unsettles social hierarchies (1995 19). Further, Rowe sees the Woman on Top ${ }^{19}$ as "characterized by excessive size, excessive garrulousness or both" (1995 37). The unruly woman, she postulates, eats too much and speaks too much - both transgressions involving the "failure to control the mouth" (1995 37). The female grotesque characters in my study certainly align with this definition of the unruly woman. Both Mrs. Hopkinson in The Semi-Detached House, and Mrs. Musgrove in Persuasion are excessive eaters who unsettle societal norms.

In the novel's exploration of the fat grotesque female, Persuasion illuminates and then challenges the assumptions surrounding the grotesque female. Austen first encourages the reader to laugh at Mrs. Musgrove by mocking her large proportions and her expressions of sorrow over the death of her worthless son, Dick. Then she critiques the readers' laughter by pointing out the double standard applied to corpulent women: they are not objects for sympathy, but objects of laughter. Therefore, their expressions of sorrow are not only inappropriate, but also fuel for

\footnotetext{
${ }^{19}$ See my discussion of Natalie Zemon Davis in Chapter 1.
} 
more derision. By mocking our stereotypical reaction to the female grotesque body, Austen suggests the possibility of disrupting accepted notions and prejudices surrounding the fat female body. Mrs. Musgrove is far from a subversive character; she does not directly challenge traditional gender or class hierarchies. Nevertheless, through her character, the novel challenges normative assumptions surrounding the role of the corpulent individual, especially the corpulent female.

In The Semi-Detached House, the Mrs. Hopkinson character also complicates the trope of superior laughter surrounding the fat body; Mrs. Hopkinson is a far more complex character than a comic foil. This character also displays a stronger potential for unsettling social hierarchies. In the liminal space of suburbia, Victor Turner's realm of pure possibility, Mrs. Hopkinson's character explores new combinations of cultural givens. More specifically, she transcends her middle-class status through her friendship with the aristocratic Lady Chester. This friendship, however, remains on equal terms only as long as the two families dwell in the suburbs together, because once the Chesters leave this liminal space for Chesterton Castle, the two families resume their traditional class roles. Despite the temporary nature of this class inversion, the Mrs. Hopkinson character demonstrates the potential of the female grotesque to subvert class hierarchies. In Chapter Three, I examine grotesque female characters who subvert gender hierarchies through their excessive talkativeness. 


\section{CHAPTER 3}

\section{Shrewish Females and Gender Inversion}

In Chapter Two I analyzed women who are deemed grotesque because of their excess body size. A woman, however, can also be characterized as grotesque by speaking too much as well as by eating too much. Both qualities involve excess around the mouth and, according to Kathleen Rowe, this excess, whether it is concerned with voracious eating or loquaciousness, is "not an innocent or uncomplicated quality" (1995 37). A grotesque woman who speaks too much is often categorized as shrewish, a woman who scolds her husband and/or dominates men through her excessive speech. Thus, these unruly women can challenge male authority via their grotesque qualities. Kathleen Rowe stresses that the topos of the talkative and shrewish women challenging male authority reverberates whenever women are "considered excessive," including too mouthy for the norms of "conventional gender representations" (1990 82). The ideal woman (though not necessarily the reality) in the nineteenth century is quiet and submissive, thus the behavior of excessively talkative women is antithetical to the norm. Talkative women, therefore, are unruly and grotesque because they are loud, shrewish, and threatening to social and political structures.

This chapter examines three garrulous female characters who are considered excessively talkative, and often shrewish, by both the narrators and by the other characters in the novels in which they appear. Two of the characters, Lady Portmore 
and Mrs. Douglas, appear in Emily Eden's 1839 novel The Semi-Attached Couple 20 while the third, Lady Olivia Tadcaster, is a character in Catherine Gore's Pin Money, published in 1831 . These characters are not only excessively talkative, but, more importantly, they also exhibit the tendency to challenge socio-cultural norms by their inversion of gender roles through their controlling speech. Mrs. Douglas, constantly gossiping and criticizing her neighbors, speaks with an authoritative tone for the entire Douglas family, while her husband, described as a "good husband," holds his opinions to himself in order to keep the peace. Lady Portmore, a gossip and selfproclaimed authority on everything from politics to relationships, regards her husband as a nonentity and flirts with other men even in his presence. Lady Olivia Tadcaster not only talks excessively, but also performs tasks that are normally considered masculine such as assuming the financial management of her nephew's debts and estate. All three women provide comic relief in these novels as they are mocked for their garrulous speech and their controlling, shrewish behavior. More importantly, these characters dominate every scene in which they appear with their comic grotesque behavior.

In this chapter, I argue that these grotesque female characters exhibit the tendency to invert gender hierarchies through their excessive and controlling speech. All three woman, at least temporarily, assume masculine roles in their relationships with their husbands, families and friends. Through these inversions, these grotesque female figures suspend the "norms and prohibitions of usual life" and thereby

\footnotetext{
${ }^{20}$ Although Emily Eden wrote A Semi-Attached Couple in 1839, it was not published until 1860 after her second novel, The Semi-Detached House, was well-received in 1859.
} 
enjoyed the freedom to explore alternatives to culturally-prescribed gender roles.

(Bakhtin 15). During this time, what Bakhtin referred to as a "sphere of utopian freedom," these characters challenge male authority as they experiment with the possibility of expanding their behavior beyond their traditional feminine roles (89). Similarly, Kathleen Rowe identifies the link between gender inversion, the "misogynist stereotype of female talkativeness," and challenges to socio-cultural norms as unruly women turn a disadvantage into an advantage (1990 82). ${ }^{21}$ Rowe concludes that an unruly woman threatens "beliefs about gender conformity" through the female mouth and its "dangerous emanations - laughter and speech" (1995 43). Audrey Bilger, in her study of Austen, Edgeworth and Burney, theorizes that the woman who "listens quietly and reveres male authority plays an essential role in patriarchal culture" while the talkative woman challenges patriarchal authority (115). The three characters discussed in this chapter never listen quietly and do not revere male authority. Instead, they express their own authority and achieve gender inversion through their excessive speech.

How much talk is concerned excessive? In general, women have been characterized as more talkative than men, a misogynist myth which, has existed

\footnotetext{
${ }^{21}$ Natalie Zemon Davis points to the prevalence of gender inversion at Medieval and Renaissance fairs and other festive occasions licensed by civil and religious authorities as well as in actual riots and protests against authorities. For example, a Skimmington was a public mockery of henpecked husbands whose wives beat them with skimming ladles. Some women rebelled against their husbands' authority; they were ambivalent figures who were seen simultaneously as "shameful and outrageous" and "vigorous and in command" (140). On other occasions, the domineering wife was the object of public ridicule. An unruly woman who thrashed and henpecked her husband could be both the leader of festivity and its butt.
} 
across cultures and historical periods ${ }^{22}$. Also, women's talk is coded negatively in a variety of ways including trivial, nagging, aggressive, tale-bearing, mischief-making, and/or gossiping. The underlying implication of this disapproval is that women speak too much, not that men do not speak enough. ${ }^{23}$ Many societies, including that of nineteenth-century Britain, do not view women's talkativeness as an admirable quality but as a transgressive one. According to Dale Spender, the talkativeness of women has been measured, not in comparison with the talkativeness of men, but with women's prescribed silence. Spender argues that "silence is the desired state" for women, so any talk a woman engages in is considered too much (42). Gloria Steinem agrees stating, "The amount of talk by women seems measured against an expectation of female silence rather than the amount of men's talk" (180). In addition, as Nancy Henley notes, women's femininity is "gauged by the intrusiveness" of their utterances (38). Voices in any culture that are not meant to be heard are "perceived as loud when they do speak, regardless of their decibel level" (91). The term shrill is applied to women who are judged to speak too loudly or in a demanding

\footnotetext{
${ }^{22}$ Janet Holmes cites a number of proverbs which demonstrate its prevalence across disparate cultures: A woman's tongue wags like a lamb's tail-they are never still-English; The North Sea will sooner be found wanting in water than a woman be at a loss for a word-Jutlandic; The woman with active hands and feet, marry her, but the women with overactive mouth, leave well alone - Maori; Nothing is so unnatural as a talkative man or a quiet women - Scottish. Where there are women and geese, there's noise-Japanese (1).

${ }^{23}$ This judgement between the amount and quality of male versus female speech appears in Dickens' representation of comic grotesque characters. Marianne Camus analyzes the differences between the qualities of excessively garrulous male and female characters in Dickens' novels. Dickens' female characters often exhibit "nonsensical speech" patterns which contrast with those of male grotesques who conversely always make sense (198). The speech of the female grotesque, she concludes, is usually "excessive and confused" while the male grotesque speech may be excessive but it is not confused (199).
} 
way--shrill feminists for example or the shrieking sisterhood of the late nineteenth

century. ${ }^{24}$

In addition, derogatory words describing speech, such as the terms gossip and

shrew, apply primarily to women. Alexander Reisman traces the development of the

word gossip from a positive term applied to both sexes into a negative term applied

to women. In the nineteenth century the noun starts to become a description for idle

talk. In his dictionary, Samuel Johnson identifies two newer meanings: Gossip could

now be used to refer to "a tippling (drinking) companion"; he also identifies a female

meaning and simultaneously relates the term to its origins: "One who runs about

tattling like women at a lying [birth]" (177). According to Reisman, the male meaning,

"tippling companion," carries a feeling of warmth and good companionship while the

female application is more hostile: women "run about" and women "tattle" (177).

Similarly, a shrew, according to the Oxford English Dictionary, is a woman "given to

railing or scolding; frequently a scolding or turbulent wife" (OED 3a). Like the noun

${ }^{24}$ Disapproval of women's perceived talkativeness has led to a variety of psychological and physical punishments in patriarchal societies throughout history. As Natalie Zemon Davis points out, the image of the "strong woman" is problematic in Medieval and Renaissance festivals: "the village scold or the domineering wife might be ducked in the pond or pulled through the streets muzzled or branked or in creel" (140). Katherine Kittredge states that women's offenses during the Renaissance were perceived as social rebellion so that punishments for female misbehavior involved public humiliation. Therefore, women with unruly tongues were subjected to the brank or the "scold's bridle," similar to the chastity belt (3). Deborah Tannen describes the physical punishments used in Colonial America similarly as unruly women "were strapped to ducking stolls and held underwater until they nearly drowned, put into the stocks with signs pinned to them, [and] gagged and silenced by a cleft stick applied to their tongues" (111). After the Renaissance, there was a move toward ever greater privatization of the response to female transgression. By the seventeenth century, for example, being a scold was no longer a punishable offense (3). Corporal punishments gave way to informal, often psychological punishments, such as social ostracism. 
'gossip,' the word shrew is applied only to women ${ }^{25}$. As I discuss in this chapter, all three of the grotesque characters are criticized as gossips, women who transgress by their volubility. The three characters also behave as shrews in their relationships with their husbands and/or other characters in the novels.

The association of women with talkativeness and conversational dominance is a common misogynistic myth displayed in late eighteenth and nineteenth-century conduct and etiquette texts. These guides display a consistent concern for encouraging silence for women, especially wives and prospective brides. For example, in his Sermons to Young Women (1767), James Fordyce urges women to "acquire a habit of fixed attention" as a form of "silent flattery truly exquisite" which is "incredibly soothing to an intelligent man" (195). Fordyce also advises, "men of the best sense [are] usually averse to marrying a witty female" (191). ${ }^{26}$ Further, a man who marries a witty woman "has found a perpetual satirist; or a self-sufficient prattler," a woman who will not promote ease for her husband (193). Similarly, John Gregory in A Father's Legacy to his Daughters (1774) praises women's "modest reserve, that retiring delicacy," which will "naturally dispose [women]to be rather silent in company" (33). Like Fordyce, Gregory encourages women to share in conversation without uttering a syllable and to participate only through the "expression in [their] countenance" (33). Mrs. Hester Chapone, in Letters on the

\footnotetext{
${ }^{25}$ Note also the link between excessive talk and mental illness in the term logorrhea. According to the OED, logorrhea is defined as "excessive volubility accompanying some forms of mental illness; also gen., an excessive flow of words, prolixity."

${ }^{26}$ Further, Fordyce warns, "we [men] cannot be easy, where we are not safe. We are never safe in the company of a critic; and almost every wit is a critic by profession" (191).
} 
Improvement of the Mind (1822), echoes Fordyce and Gregory when she writes that a "a young woman can hardly be too silent and reserved in company and certainly nothing is so disgusting in youth as pertness and conceit" (130-1). Further, a woman's looks should show her attentiveness as "a respectful and earnest attention is the most delicate kind of praise, and never fails to gratify and please" (131). In The Daughters of England (1843), Mrs. Sarah Ellis advises wives to remember that their "highest duty is so often to suffer and be still" (73). ${ }^{27}$ These texts make clear the connection between a quiet woman and her success in finding a husband. They also emphasize the belief that talkative women do not make good wives. These authors also warn women that if they want to get husbands, they must not be witty. Presumably a witty woman is an unruly woman who will criticize her husband just as Mrs. Noah and Lady Skimmington dominate and disobey their husbands.

Numerous literary examples demonstrate a link between women's talkativeness, their unruliness, especially their lack of submissiveness, and comedy. In Literary Fat Ladies, for example, Patricia Parker traces literary examples of the connection between women's excessive fatness, willfulness and excessive speech from the Old Testament to the twentieth century. She finds that through both her body and her speech, the unruly woman violates the unspoken feminine sanction against making a spectacle of herself. Anne Feltovich locates the "stereotype of [female] gabbing" in

\footnotetext{
${ }^{27}$ Of course, etiquette and conduct books are "repositories of cultural beliefs" about the stereotypical characteristics linked to men and women (Kramer 2). These ideals represented by these books do not necessarily reflect how women actually behaved during the nineteenth century. Similarly, Martha Vicinus argues (20) "that one could be a happily married woman without subscribing to the demands of an ideal" (20). In fact, Vicinus posits that the "clearest characteristic of the mid-Victorian period was how few women of character fit the ideal lady" (20).
} 
the comedies of Aristophanes where male characters considered females "naturally endowed with the gift of gab" (94). She also identifies in Greek and Roman drama "an organized effort by men to suppress the voices of women" and theorizes that when females are able to overcome this silence, they are seen as "disruptive to social order" (13). In medieval mystery plays, Mrs. Noah is comically represented as a sharp-tongued shrew who takes pleasure in tormenting her husband; she not only uses abusive language to her husband but also refuses to board the ark. Natalie Davis' review of Medieval and Renaissance literature reveals amusing husband dominators everywhere in popular literature, who represent unruly traits such as anger, whorishness and talkativeness which the "church repressed in favor of chastity, silence and meekness" (134). A frequent carnival character, Lady Skimmington, was a comic female masquerade of "strident, wifely aggression" who is mocked alongside her henpecked husband (Russo 216). In nineteenth-century literature, there are numerous examples of overly talkative female characters such as Miss Bates in Jane Austen's Emma, Flora Finching in Dickens' Little Dorrit, and the characters I analyze in this chapter - Lady Olivia Tadcaster, Mrs. Douglas, and Lady Portmore. ${ }^{28}$

\footnotetext{
${ }^{28}$ The trope of women's talkativeness continues even in the twenty-first century under the guise of science. In her 2006 book, The Female Brain, neuroscientist Louann Brizendine reports that a woman uses about 20,000 words per day while a man uses about 7,000. Despite the fact that Brizendine's claim was discredited, the media continued to circulate this statistic and the stereotype persists. Twenty-first century researchers, despite numerous experiments, have never been able to confirm this stereotype. For example, in 2007 Matthias Mehl et al. studied male and female word usage in 396 university students from Texas, Arizona and Mexico. In order to avoid the possible inaccuracies associated with self-report, participants carried a digital recorder, a measure designed to capture their real-life talkativeness. Mehl concludes, "on the basis of available empirical evidence, that the widespread and highly publicized stereotype about female talkativeness is unfounded" (Mehl 82). They found, contrary to popular wisdom, male and female college students speak the same number of
} 


\section{Pin Money}

Catherine (Moody) Gore (1798-1861), the author of Pin Money, wrote prolifically during the early- and mid-nineteenth century in order to help support her family's precarious finances. Her publications included more than 70 poems plays, tales, and novels. In 1831 alone, she published four novels, including Pin Money. Many of her texts focus on the upper classes and class differences which were reflected in her own life experience. While her father was a wine merchant, Gore married into the fringes of the aristocracy. Her husband, Charles Arthur Gore, an officer in the 1st Regiment of the Life Guards, was related to the Countess of Arran, a governess to Princess Charlotte and a leader of fashion. Gore's daughter Cecilia eventually married into the aristocracy.

In 1833 Gore and her family moved to the Continent to escape Charles Gore's debts in England. While abroad, Gore ran a salon at her house in Paris where she entertained the French literary and political elite. She was acquainted with a number of important literary figures in London and in Paris. Gore was also the first woman since late eighteenth-century playwrights Elizabeth Inchbald and Hannah Cowley to achieve a professional career as a dramatist. Eleven of Gore's plays (from one-act farces to high comedy) were performed with varying success on the London Stage. Her comedy, Quid Pro Quo, won a prize for "the best modern comedy illustrative of

words daily--about 15,000. Interestingly, the greater variability showed up not between the sexes but within them. Males accounted for both the most economical speaker at 5,000 words per day as well as the most verbose at 47,000 words per day. Even in the absence of empirical proof, modern society continues to characterize women as more talkative with the underlying implication that women speak too much, not that men do not speak enough. 
British manners" (Brown et al). Gore is best known for her position as a leading

novelist in the "silver-fork" genre and, many of her novels, including Pin Money, belong to that genre ${ }^{29}$.

The silver fork novel ${ }^{30}$, most popular during the late 1820's and 30's, focused on the fashionable life of aristocrats during the Regency period (1811-1820). Silver fork novels attracted two classes of readers-- upper-class fashionables, who read the novels to find portraits of themselves and their friends (or their enemies), and members of the middle class, who aspired to join the ton and read the novels to educate themselves in the workings of high society (Wilson 248). The class politics of this genre are reflected by this dual readership. These novels were also satirical in that they allowed middle-class readers to indulge in the frivolity of the aristocracy while ridiculing it at the same time (Alexander 297). Similarly, in Pin Money, Gore

\footnotetext{
${ }^{29}$ In his 1847 "Punch Prize Novelists" Thackeray's referred to Catherine Gore as the most prolific of the silver fork novelists.

${ }^{30}$ The term silver-fork originated in 1827 with William Hazlitt's criticism of these novels for their "presumed insider descriptions of fashionable high life" and for their tendency to inform their readers of the striking fact that "the quality eat with silver forks" (Wagner 2009 182). Tamara Wagner notes that these novels offered "titillating yet often moralizing accounts of the more flamboyant high life of the recent past (2009 182). Contemporary readers, she concludes, enjoyed the exotic, yet corrupt, nature of the aristocratic world, a "way of life that was seen to be fading" (2009 182).

Although the genre has been mocked as frivolous, most notably by George Eliot in "Silly Novels by Lady Novelists" in the Westminster Review, critics point to both its complexity in terms of its ambivalence and its satirical nature. Sarah Alexander, for example, points out how silver-fork novels both "glamorize and censure" the decadence of the Regency aristocracy (286). Tamara Wagner argues that in their "lavish descriptions" of expensive entertainments, the texts were alternately "fascinated and repulsed" by the decadence it showcased (2005 446). The genre, though nostalgic for the romanticized past of the Regency period, was consistently satirical. These novels were also satirical in that they allowed middle-class readers to indulge in the frivolity of the aristocracy while at the same time as ridiculing it (Alexander 297). Winifred Hughes discusses the novels in terms of "a radical instability of tone" as they could be read both as celebrations of the aristocratic ascendancy and as devastating satires (Alexander 296). Wagner theorizes that the genre proposes the term "silver-fork sensation novel" to explore the literary legacies of silver-fork fiction for later women's writing. Wagner argues its "versatile influence on subsequent literary developments" though she admits the genre is now primarily known through its parodies, such as Vanity Fair.
} 
presents the fashionable world not only as "enticing, glamorous and social" but also as corrupt and false which in this novel proves antithetical to marital happiness.

Like many of Gore's novels, Pin Money deals with love and marriage among the upper classes of the Regency period. In Pin Money, Gore rails against the indiscriminate spending of the fashionable as well as their lack of education in money management. The plot of Pin Money follows the financial and marital difficulties of the young and inexperienced Lady Frederica Rawleigh during her first London season as a married woman. The marriage articles have given Frederica a generous settlement of pin money, but she has never handled money before. The insidious influence of her indiscriminate-spending friends in the fashionable world as well as her own lack of experience and education in managing money soon lead Frederica into debt. Too ashamed to admit her mistakes, she tries to hide her spending and debt from her husband, Sir Brooke Rawleigh. This lack of communication threatens Frederica's relationship with Brooke, a new MP who has committed some financial indiscretions of his own. Although a comic novel, Pin Money conveys a serious message about dire consequences of a woman's lack of education in handling money.

\section{Lady Olivia Tadcaster}

My analysis centers on Frederica's officious aunt, Lady Olivia Tadcaster, a grotesque character who comically outtalks morning callers, interferes with every detail of her acquaintances' lives, and shows incredibly poor judgement in introducing lower-class interlopers into upper-class society. Despite her occasional bad social judgement, she loves business and is quite knowledgeable about financial 
matters; she manages her and their finances far more effectively than her male relatives. The novel begins with negotiations for the marriage articles between Lady Frederica Rawdon and Sir Brooke Rawleigh. As soon as her niece, Frederica, becomes engaged, Lady Olivia insists on a settlement of pin money for Frederica so that Frederica will have greater financial independence in not having to ask her husband for money. Declaring she loves business, Lady Olivia not only negotiates her niece's marriage settlement, but also plays a masculine role in managing her nephew's precarious finances. Lady Olivia also dominates Frederica throughout the novel through her talkativeness, her interference, and her intrusiveness. She criticizes Frederica's choice of friends, dress, and even her oyster supplier. Although a minor character in the novel, Lady Olivia both provides comic relief from the Rawleighs' marital problems and dominates every scene she appears in through her excessive talkativeness and bossiness. Through Lady Olivia's dominance, talkativeness, and her active interference in her family's financial affairs, she frequently inverts gender roles and challenges the cultural assumptions surrounding women's roles.

Lady Olivia's garrulousness is clear from the beginning of the novel when, upon hearing of her Frederica's engagement, she visits her niece with "a 1,000 things to say" (7). Later, after Frederica's marriage, Lady Olivia outtalks another visitor at Frederica's house as "she would have done O'Kelly's parrot which chattered incessantly for one hundred years" (64). On one occasion Lady Olivia rouses Lady Launceston out of her sleep at 8 am and "talks her into a fever" (121). Lady Launceston must return to bed after "such a shock and such an exertion" as her 
sister's visit. Lady Olivia's talkativeness is so excessive that her family members try to avoid her. On one occasion, Sir Brooke hides in his study until her visit is over. Her nephew, Lord Launceston, exclaims, "that foolish old woman's twaddle" makes him miserable (304). She speaks so incessantly that she continues to talk after leaving the drawing room; Frederica hears the "receding murmurs of Lady Olivia Tadcaster twaddle" as she walks down the stairs (28). Lady Olivia is also such a "notorious gossip" that she quizzes Lady Launceston for every detail of Frederica's engagement causing Frederica's hesitation to confide in her (77). She involves herself in her friends' and acquaintance's business ranging from their travel arrangements to social introductions. Lady Olivia is never silent; at the end of the novel, the narrator describes that her delight over the family celebration of her nephew's engagement, "almost silenced her accustomed garrulity!" (312).

Lady Olivia's conversation is both confusing and amusing as she moves rapidly from one subject to another. She begins each appearance by recounting her involvement in multiple tasks and social engagements. In one scene she describes how she has a different social engagement for every hour of the evening: "a conversazione, concert, and assembly" (72). She pledges herself to spend all her free evenings with an ailing Lady Launceston and then lists her extensive engagements; she is busy every night for at least one week. On another occasion she declares she has fifty appointments before dinner time. Lady Olivia often interrupts conversations to interject her own concerns with an insensitivity to the mood or chief concerns of her victims For example, she intrudes upon Frederica's confidential conversation with 
a friend to engage in a long, involved and boring explanation concerning her efforts to get a ride to a party when her carriage is otherwise engaged. One acquaintance remarks that her conversation announces her as a "mere egotist" (289). She does indeed seem oblivious to how others feel about her.

Just as her family finds her exhausting, her peers in upper-class society regard her as the "most insupportable of human bores" (93). Further, they view her as a "tiresome, restless woman" who is "a bore to everybody" (161). The only times they find her acceptable and worthy of visiting are when she can perform a task or recommendation for them such as when "Lady A or Lady B had a place to find for a favorite servant" (161). Upper-class society mocks Lady Olivia for her absurdity such as introducing a family she meets in Holland with supposedly aristocratic connections to London society only to later discover they are actually Bohemian jugglers. After discovering her mistake, Lady Olivia decides to host a Breakfast to "relieve the stigma of her introducing jumblers into society" (161). At first her friends and acquaintances receive the breakfast invitation with "coldness or contempt" and they refer to her as a "foolish old woman" (162). The Breakfast is well attended, however, only because no other balls or other entertainments are given on the same day. Nevertheless, the guests fear, because of Lady Olivia's personality, that the Breakfast will be "tedious" (174).

Lady Olivia is not only a talkative bore but the narrator also describes her as "dictatorial" (49) and "inquisitive" (90). Early in the novel, Frederica tells Sir Brooke of the necessity for admitting and conciliating the "fussiest of aunts; who would 
otherwise beset their union with a thousand well-meant impediments" (4). Lady

Olivia, as I explain below, forcefully interferes in their marriage settlements. In fact, she criticizes, controls and interferes in every aspect of Frederica's life. She constantly drops by unexpectedly to monitor Frederica's activities. On one occasion, she "bursts in while [Frederica] is looking at court dresses" for her presentation at St. James (25). During this visit, she criticizes the selection of dresses saying Frederica is "mad to throw away [her] money in this sort of frivolous manner" (26). Further, she castigates Frederica's closest friend as a "lightheaded, unprincipled little person" and threatens to speak to Frederica's husband about her (26). Frederica wishes her aunt back in Rotterdam where she was recently traveling.

Lady Olivia interferes in small as well as large issues. For example, she constantly quizzes Frederica on her whereabouts and insists she should keep her informed about her destination during her morning rides. Also, in an infuriating and humorous scene, she drops in, uninvited, for dinner and criticizes the food and interferes in Frederica's choice of an oyster supplier. Lady Olivia also strongly disapproves of her nephew's flirtation with his mother's hired companion and tries to involve both Frederica and Sir Brooke in dividing the couple. She humiliates Sir Brooke by sending her footman into his club and keeps him in her carriage for a quarter of an hour as she complains about this romance. Embarrassed at her summons, Sir Brooke is certain of "being quizzed to death on [his] return to the club" (33). Lady Olivia strives at and usually succeeds in interfering in and dominating her relatives' lives. This interference covers not only their daily lives but larger financial matters as well. 
Pin Money begins with the engagement between Lady Frederica Rawdon and Sir Brooke Rawleigh. As soon as she hears about the proposed marriage, Lady Olivia focuses on the negotiations for the marriage articles, especially on pin money for Frederica. Frederica's mother, Lady Launceston, declares herself ignorant of money management, her father has died years earlier, and Sir Brooke dislikes business (in fact offers Lady Launceston carte blanche), so Lady Olivia and her lawyer assume control of the marriage settlements. Business-loving Lady Olivia immediately calculates a fair settlement for her niece; because Frederica brings 10,000 pounds to the marriage, she should "demand 3,000 jointure and 500 pin money" (7). Frederica objects to pin money first because she does not want Brooke to think her greedy and secondly because, in her opinion, receiving an allowance "places one exactly on a level with the butler or the dairymaid" (8). Lady Olivia critiques her romanticism and argues, "Do you suppose ... any other person of fashion of your acquaintance, condescends to go blushing to her husband for a twenty-pound note, if she wishes to perform some charitable action - or subscribe to some laudable institution -or pay her shoemaker's bill?" (8). Confronted with the choice of becoming a beggar or achieving financial independence, Frederica reluctantly accepts the pin money though she reduces it to 400 pounds. Similarly, forced to recall her husband's parsimoniousness when confronted with her clothing bills, Lady Launceston acknowledges that an independent income might prove less humiliating than her marital finances. According to the narrator, under Lady Olivia's management "as rigid an act of marriage settlement was signed in the drawing-room in Charles-street as if 
Sir Brooke and Lady Rawleigh were about to marry chiefly in contemplation of a divorce; and to swear an eternal unity of mind, body, and estate, chiefly for the maintenance of separate interests and opposing rights" (9). Although bride and bridegroom are marrying for love, Lady Olivia regards their union primarily as a business arrangement.

Lady Olivia shows her unfeminine fondness for business and money in other areas of her life as well. After her father's death (years before the novel's opening), Lady Olivia brought an ultimately unsuccessful chancery suit against her father's executors including her brother, Lord Trevelyan. Lady Olivia's brother-in-law and Frederica's father, Lord Launceston, criticized her behavior in bringing the suit by alluding to her lack of "female delicacy" (4). Lord Launceston also amused himself by calling her Widow Blackacre. Widow Blackacre, a comic character in William Wycheryle's The Plain Dealer, is "a masculine, litigious...headstrong woman" (Bartleby.com). Lady Olivia's engagement in the chancery suit is regarded by her male relatives as similarly masculine behavior, lending credence to her gender inversion and transgressive behavior.

In addition to negotiating her niece's marriage settlements and bringing a lawsuit against her brother, Lady Olivia also manages her nephew's estate. She does this even though he is not a minor or disabled in any way; he is merely careless with money. Lady Olivia does not regard her role as a burden, although she professes to complain about her numerous responsibilities. The present Lord Launceston, Frederica's brother, knows he is "a favorite with Lady Olivia because he resigned into 
her hands the payment of a mortgage on his estate and half a dozen troublesome annuities" (11). Similarly, he declares, "I oblige Lady Olivia very materially by leaving the arrangement of my affairs in her hands" (161). Lady Olivia relishes her role, bragging to Frederica about being "in the secret of my nephew's embarrassments," having "his rent-roll by hearts, and the list of his mortgages by head" (86). When Lord Launceston considers marriage to a rich merchant's daughter in order to repair his finances, his sister Frederica is horrified at the idea of his marrying outside his class, especially considering his proposed mother-in-law's excessive vulgarity. Lady Olivia, however, with her near-obsessive concern about business and money, approves of the addition of "a little city gold" to "assist in emblazoning the escutcheon" (87-88). She revels in the possibility of paying off the mortgages on Lord Launceston's estate. Further, she accuses Frederica of "narrowness of mind" saying "intellectual people," presumably like herself, "are above such obsolete prejudices" (88). Again, in her management of her nephew's financial embarrassments, Lady Olivia adopts the traditionally masculine role of money and estate management, reversing conventional, nineteenth-century gender roles.

In contrast to Lady Olivia's business acumen, the men in Pin Money are woefully inadequate financial managers. Lord Launceston, as I have discussed, has numerous mortgages on his estate. He has been careless with money from a young age; he was in debt before leaving Eton. He even judges his new brother-in-law, Sir Brooke, "as unnaturally reserved and cautious" (11). When Lord Launceston finds out how little debt Sir Brooke has acquired after six years in London, he pronounces him "too 
prudent by half" (11). Lord Launceston recognizes his own improvident ways, at one point referring to his "follies and profligate extravagance" and describing his career as "everything that is disgraceful and contemptible" (208). His attempts to reform, while including modest reductions in spending, mostly involve marrying into wealth. While Lady Olivia fulfills the more masculine role of managing his money, Lord Launceston conforms to the more feminine role of marrying for financial support ${ }^{31}$.

Although Sir Brooke has not encumbered his estate with mortgages, he also demonstrates deficiencies in his financial management. From early in the novel, Sir Brooke warns Lady Frederica to avoid unnecessary expenditures because of the excessive amount of money he has spent during the year on improving their country estate (23). In fact, his warnings inspire part of Frederica's overspending her pin money to compensate for his economizing. Sir Brooke not only spends money improving his estate but he is "alarmed at the amount of money" he spends to achieve his seat in Parliament (118). The narrator makes it clear that his process of achieving a seat in Parliament is shameful, stating that it is an "indiscreet revelation [which] shall never be traced to our pages" (47). In addition to his criticizing his excessive and sordid expenditures, the narrator casts doubt on Sir Brooke's intelligence, describing him as "not likely to attract the attention of the world by marvelous intellectual endowments" (141). Sir Brooke himself doubts his own intellectual powers. Although he expected to "derive considerable self-importance"

\footnotetext{
${ }^{31}$ I do not mean to imply here that Lord Launceston is the only aristocratic man to marry into a wealthy merchant family. The profligate young male aristocrat is a common character in silver fork novels. Lady Olivia's officiousness and business acumen, however, provide a striking contrast to Launceston's more passive approach.
} 
from his seat, he finds himself lowered in his own esteem (141). Like Lord Launceston, Sir Brooke spends his money unwisely and he is even partially responsible for Frederica's mismanagement of her income. Although Lady Olivia has no input into Sir Brooke's finances or the management of his estate, her intelligence and business acumen, qualities coded as masculine, serve as a contrast with his lack thereof.

Lady Olivia, in fact, serves as a proto-feminist in Pin Money as the following passage indicates,

There was nothing so revolting to the feelings of Lady Olivia Tadcaster as to be termed, even inferentially, "a female," -a name she estimated as only worthy to designate a dairy-maid, a milliner's apprentice, or the gentle sex of the cynoaephalous species. She was willing at all times to take her stand in any list, for the equality of the sexes and prerogative of the petticoat; which she considered disparaged by such contemptuous mention (51).

As this passage demonstrates, her dislike of being termed "a female" reveals Lady Olivia's belief in the "equality of the sexes," certainly a transgressive opinion in early nineteenth-century England. Further, male characters criticize her for her masculinity in her participation in a chancery suit. Sir Brooke also faults the offensiveness of Lady Olivia's "latent love of business" and fears pin money may arouse this quality in 
Frederica (13). According to Brooke, pin money, and Lady Olivia by extension, is a "pernicious ministrant to feminine independence" (57). Lady Olivia's behavior and her beliefs are transgressive in their encouragement of feminine independence and equality.

Lady Olivia's interference in her family's financial arrangements proves temporary. By the end of the novel, Lady Olivia loses her grasp over her nephew's finances and fails in her attempt to acquire pin money for her niece, but presumably continues to interfere in the details of others' lives. Lord Launceston marries Lady Mary, his cousin, an aristocratic heiress, so will presumably not have the need for Lady Olivia's management of his debts. The discussion on marriage settlements is between Lady Launceston and Lady Mary's father. While at the beginning of the novel, the marriage settlements were controlled by Lady Olivia, at the end of the novel, Lady Olivia is excluded from the conversation. In addition, a friend of Frederica's, who knows about Frederica's money problems, jokingly urges Frederica to "interpose a word of advice on the important article of Pin Money!" (312). The humor points to the disaster pin money has proved to be for the Rawleighs' marriage as Frederica's mismanagement lead to her secretiveness and deception as well as to Brooke's subsequent suspicion and jealousy.

Despite Lady Olivia's goal of encouraging Frederica's financial independence through pin money, Frederica rejects this freedom and gives up her right to her own income unless she ever becomes "as worldly-wise as my aunt Olivia" (301). In an apparent repudiation of the business-like nature of the marriage settlement drafted 
by Lady Olivia, Frederica tells her husband that "nothing ever shall be, legally

specified between us" (302). Further, she vows she will "cherish, for life, the recollection of all I have suffered through my ignorance and neglect of the value of money" (302). Frederica's mismanagement of her pin money strongly contrasts with Lady Olivia's business acumen. She ends up in serious debt despite her aunt's scrutiny of her spending. Despite her profligacy, Frederica is very sensitive to the dishonor of her debts. Unlike her brother who has ceded responsibility for his financial affairs to Lady Olivia, Frederica is very uncomfortable with her financial ignorance. Her mother set an example of "strictest regularity in her domestic affairs and fulfilled with righteous diligence every duty of her sex" (278). Here, Frederica rejects her aunt's proto-feminist lifestyle for her mother's traditional habits ${ }^{32}$. Lady Olivia has failed in her desire to encourage financial independence in her niece. Lady Olivia's ascendance over the family financial business proves temporary. The temporary nature of her assumption of this masculine role is reminiscent of Bakhtin's theory of inversions in carnival where participants temporarily assumed authoritative roles. A hierarchical inversion such as a gender inversion takes place temporarily, during a time of play and freedom, and reveals the possibility for different societal

\footnotetext{
32 April Kendra argues that the ending suggests a movement toward a "more equitable model of marriage" based on open communication and joint decision-making (Para. 19). Sir Brooke promises to conquer his jealousy, and reminds Fredericka that she "retains the right to claim her pin money at any time" (Para 19). Although their marital issues seem resolved at the end of the novel, their marriage hardly seems equitable at least by modern standards. Frederica may have the right to reclaim her income, but submitting all her bills to Sir Brooke for payment, and approval, hardly seems like joint decision-making. Kendra also points to Gore's criticism of Frederica and Brooke's "folly and financial imprudence" (Para. 17) This disapproval is certainly present but I argue, instead, that Gore is highlighting and criticizing Fredericka's lack of financial education; during her own marriage her mother was kept in the dark about finances as is her daughter.
} 
and cultural structures. This time of play and freedom resembles a liminal space, a state of "betwixt and between" the normal, day-to-day cultural and social states. Turner described it as a time of enchantment when anything might happen (1979). Turner argues that inversion, like liminal spaces, may "break people out of their culturally defined, even biologically ascribed roles, by making them play precisely the opposite roles" (1972 287). In Pin Money, we see the inability of the male characters to perform their culturally-sanctioned tasks surrounding money and estate management while a woman, Lady Olivia Tadcaster, through her grotesque qualities of excessive talkativeness and shrewishness, temporarily assumes control of these "masculine" tasks and succeeds at them. During this time of freedom, we see the possibility for women's equality, and perhaps even superiority, at money management. The grotesque character of Lady Olivia allows the reader to recognize and explore the artificiality of gender roles at work in the mid-nineteenth century novel and raises the possibility of new gender roles and cultural ideas.

The Semi-Attached Couple

Emily Eden's The Semi-Attached Couple (1839) satirizes the economic basis of nineteenth-century, upper-class marriages and contrasts it with middle-class sentiments surrounding marriage. Miss Eden explores the question of what happens to a man, immediately after marriage, who believes his wife dislikes him and married him only for his wealth and status. The novel focuses on newlyweds Lord Teviot and Lady Helen (Beaufort) Teviot. Lord Teviot is very possessive and feels threatened by 
Helen's presumed lack of affection for him. He is even jealous of Helen's closeness with and love for her family. The more jealous and controlling Lord Teviot behaves, the more Helen questions her feelings for him. Most of the novel is set at a house party at St. Mary's, Teviot's grand estate, only weeks after their marriage. The house party consists of upper-class society figures, such as Lady Portmore who is determined to disrupt the Teviot marriage; prominent political figures, such as Mr. G, the future prime minister; and Helen's family (her brother Lord Beaufort and her parents Lord and Lady Eskdale). The middle-class Mr. and Mrs. Douglas, neighbors of the Beaufort family, also join the gathering. A subplot follows the rocky romance of the Douglas' younger daughter Eliza with Colonel Beaufort, Helen's cousin.

My analysis of the novel focuses on two excessively talkative, grotesque characters: Mrs. Douglas and Lady Portmore. Mrs. Douglas, although a long-time neighbor and friend of Helen's mother, Lady Eskdale, incessantly finds fault with and gossips about her neighbors. She frequently focuses on the appearance and spending habits of the wealthy Beaufort family. She is both the neighborhood gossip and a shrewish wife. Although many of her criticisms arise from jealousy and ill-nature, at times, through her disapproval, Mrs. Douglas discerns truths that other characters miss. Despite her incessant gossiping about Helen's family, Mrs. Douglas does, however, have a soft spot for Helen herself, the youngest Beaufort daughter. Although equally talkative and full of gossip, the aristocratic, flirtatious Lady Portmore provides an interesting and amusing contrast to the moralistic, middleclass Mrs. Douglas. Lady Portmore spends the majority of the novel as Helen's rival 
for Lord Teviot's affections and succeeds, through her clever rhetoric, in convincing him that Helen has no feelings for him. Mrs. Douglas instantly recognizes Lady Portmore's immoral nature and dislikes Lady Portmore from their first meeting. Toward the end of the novel, the two women confront one another in an amusing battle of words. They are both infamous for their loquaciousness and controlling natures. They also, like Lady Olivia, dominate every scene in which they appear. ${ }^{33}$ The excessive talkativeness and outrageous behavior of both characters provide comic relief from the serious nature of the novel's central story - the breakdown of Lord Teviot and Helen's marriage. Through their dominance over their respective husbands, their talkativeness, and their controlling natures, both characters invert gender roles and thereby challenge the nineteenth-century cultural assumptions surrounding women's roles.

\section{The Grotesque Mrs. Douglas}

Mrs. Douglas' excessively talkativeness arises from her constantly criticizing and gossiping about her neighbors. According to the narrator, Mrs. Douglas' sharp tongue arises from her own lack of beauty, "her excessive plainness," and her subsequent desire "to bring others down to her own level" (21). Her comments about her friends and acquaintances invariably focus on: "how old she is looking!- how she is altered!" (21). For example, upon hearing that Lady Eskdale's daughter is engaged to a wealthy man while the Douglas daughters are still unmarried and unattached, Mrs. Douglas declares that Lady Eskdale looks as "old as the hills....I never saw anyone so

\footnotetext{
${ }^{33}$ Their speech and behavior often extend scenes, creating a type of 'fatty' text as Patricia Parker theorizes in Literary Fat Ladies.
} 
altered" (19). At Helen's wedding, Mrs. Douglas observes the "frightful effect" the light from the stained glass has on Lady Eskdale's looks and thinks “Lord Eskdale's hair has grown suddenly grey" (53). Mrs. Douglas also links her judgement of a person's character with her opinion of their appearance. After meeting Lady Portmore, Mrs. Douglas thinks her "unprincipled" and so employs her standard criticism, "excessively old-looking" (181). Just as her opinion of another characters' appearance aligns with her displeasure and jealously, a good mood leads to an improvement in judgement. For example, when her younger daughter is engaged to Lady Eskdale's nephew, in her "state of intense felicity," Mrs. Douglas finds Lady Eskdale looks very young for her age (283).

Mrs. Douglas is quite forthright about her negative attitude toward others stating that, "I very seldom do like anybody" (121). Even when she enjoys a houseguest's visit, she hates to admit it and tells her family, "I never took a fancy to anybody in my life. If people have any striking qualities, they are generally bad ones" (191). Because Mrs. Douglas does not hide her negative judgements, the other characters are quite well aware of her unpleasant gossiping. Lady Eskdale's older daughter, for example, complains, "Mrs. Douglas hates so many people" (212). The insouciant Colonel Beaufort, contemplating marriage with Eliza Douglas, states that he does not "dislike ill-natured women" but predicts that his future mother-in-law "will occasionally squeeze lemon-juice in his stagnant cup" (282). As I discuss below, however, Colonel Beaufort eventually tames his shrewish mother-in-law. 
Mrs. Douglas' unpleasantness extends to her servants as well as to her acquaintances. She is distrustful of them and governs them through ill-treatment rather than through building loyalty. When she discovers that her servant is gossiping with Lady Eskdale's maid, she tells her husband, "I am always glad of an opportunity to tell servants what a thoroughly bad race I think they are" (63). Mr. Douglas responds with sarcasm, "That must be encouraging to them and produce a great increase of attachment to yourself" (64). Mrs. Douglas does not feel shamed by this response saying she manages her servants better than anyone. Her method consists of : "never letting them have their own way on any one point; and as for attachment, you might as well expect it from this table" (64). Mrs. Douglas measures her clever management of the servants by "how well she contrived to make her servants hate her" (64). She clearly does not care if her servants like or respect her as long as they are obedient.

Mrs. Douglas is especially critical of Lord Teviot, Helen's new husband, calling him "ill-tempered, disagreeable, [and] odious" (44). She observes his "savage temper" and predicts Helen "will lead a wretched life" (45). Some of her prejudice against Lord Teviot is class-based as she refers to him as one of the "worst specimens of class dandy I ever saw" (53). The narrator, by mocking Mrs. Douglas' nastiness from the beginning, has prepared the reader to dismiss her opinions as unfounded and solely motivated by jealousy. In this case, however, Mrs. Douglas is prescient in seeing Lord Teviot's ill-temper. As the novel continues, we see Lord Teviot's jealousy and illtemper at play, causing Helen much confusion and unhappiness. Interestingly, no one 
in the Beaufort family, including Helen's favorite sister and her loving mother, notices Helen's discomfort with Lord Teviot or his constantly questioning her feelings for him. They anticipate only a highly successful, financially advantageous marriage. Mrs. Douglas is not just a nasty-tongued gossip, but is also remarkably astute in her observations.

The majority of Mrs. Douglas' gossip is motivated by a class-based jealousy as it centers on the Beaufort family and their wealth. Mrs. Douglas and Lady Eskdale were not only neighbors but close friends while their children were young. Then, the Eskdales "received an accession of fortune and spent a great part of each year in another county, and also in London" (22). The Douglas family, on the other hand, remained in the country and "mixed more with their second grade of neighbors" (23). Mrs. Douglas' criticisms focus on the Beaufort's display of wealth. For example, she mocks the display of the "regiment of footmen drawn up on either side" of the long staircase at Eskdale castle (19). She contrasts her "plain commonsense" to Lady Eskdale's status as a London lady saying "the tricks and ways of these London ladies are amazingly entertaining" (65). When Lord Teviot leaves Helen for a diplomatic mission, Mrs. Douglas predicts a pessimistic future for Helen and "all those Beauforts" who will all outlive their good "looks by the time they are 30" (182). Her resentment of wealth and class status is consistent with her attitude toward Lord Teviot's supposed dandyism. It also shows in her class consciousness around the heiress Mary Forrester, Helen's friend, and Lady Portmore. When Mary Forrester comes to stay with the Douglas family, Mrs. Douglas watches her closely to see 
"whether she turned contemptuous at the sight of a commonplace, moderate-sized home" (194). When she discovers Mary is not proud and is establishing a close friendship with Eliza Douglas, Mrs. Douglas grudgingly admits to a liking for her. In contrast, she never, as I discuss below, modifies her suspicion of and dislike for the aristocratic Lady Portmore.

Consistent with her judgments about other people, Mrs. Douglas demonstrates her grotesque qualities by her excessive and outspoken criticism of social events. When she attends a dinner with the Eskdales, Mrs. Douglas holds herself ready and able "to detect what might be amiss, and to say what would be disagreeable" (38). She turns the kindness of an invitation to Helen's wedding into a "great grievance" (51). She complains that holding the wedding in the neighborhood forces her to witness the Eskdales' prosperity. Although she despises and denigrates the Eskdales' love of fashion, she hypocritically decides to spend a great deal of money on a new dress and bonnet for the wedding. Her hatred of the wedding also reveals her cynicism about marriage. She thinks it "absurd to assemble a crowd to witness a man and woman promising to love each other for the rest of their lives when we know what human creatures are--men so thoroughly selfish and unprincipled, women so vain and frivolous" (51). In the divergent attitudes displayed by the narrator, the novel reflects the ambivalent nature of the readers' perception of the grotesque, by both mocking her and inviting the reader's respect for her insights. Although the narrator satirizes Mrs. Douglas' excessively critical attitude toward the wedding and 
its participants, the novel also credits her judgement by critiquing the business-like nature of aristocratic marriages and the potential hypocrisy of marital partners.

Similarly, she views love in marriage with cynicism saying that men are too "selfish and unprincipled" and women are too "vain and frivolous" to follow their marriage vows with sincerity (51). Her distrust of Lord Teviot and skepticism surrounding the Teviots' marriage vows extends beyond Helen's marriage; it is part of her general cynicism surrounding men and marriage. For example, when her daughter Sarah becomes engaged to Mr. Wentworth, a well-off, respectable gentleman, Mrs. Douglas' reaction is mixed. One the one hand, she likes Mr. Wentworth and is pleased at the engagement, but she also "knew that there was no trust to be placed in any man on earth" because men "were all as hard as boards, and as fickle as the winds, and one more selfish than another" (120). Further, although nobody could doubt Mr. Wentworth's intentions, it would not surprise her for a moment if he "jilted Sarah at last" (120). Mrs. Douglas also points out the financially-based marriages of the Beaufort daughters by mocking Lady Eskdale's letters in which she praises each bridegroom's principles, good looks, and worldly prosperity and the couple's "long attachment," which consists of a mere six weeks (23-4). According to Susan Fellows, through these letters and Mrs. Douglas' reaction to them, Eden "censures the commodification" of marriage in upper-class society (112). The novel, through this grotesque character, acts to reveal and challenge cultural assumptions surrounding romantic marriages. In this aspect, The Semi-Attached Couple bears a strong resemblance to Pin Money. 
Mrs. Douglas' cynicism about love in marriage may at least partly arise from her own marriage. The narrator tells us that Mr. Douglas married her only because she was an heiress. Because of her excessively plain looks, and perhaps because of her sharp tongue, "no one could suppose he had married for love" (21). Judith Plotz argues that Eden created the Douglas couple in homage to Austen's Mr. and Mrs. Bennet from Pride and Prejudice. According to Plotz, Mr. and Mrs. Douglas recapitulate the Bennets as the "foolish wife" and the "clever ironic husband sparring" over everything (165). Tamara Wagner agrees, stating that Mr. and Mrs. Douglas' conversation at the beginning is "eerily reminiscent" of the opening of Pride and Prejudice. Certainly, Mr. Douglas at times speaks ironically at the expense of his wife. For example, when Mrs. Douglas describes how badly she treats her servants, Mr. Douglas responds sarcastically by suggesting how this attitude must encourage them. Further, when their daughter Eliza receives an invitation to stay at Eskdale Castle, Mrs. Douglas quickly switches from castigating the "manners and customs of Eskdale Castle" to praising Lady Eskdale. Mr. Douglas is quick to point out her hypocrisy. Unlike Mrs. Bennet, however, who frequently misunderstands her husband or reacts emotionally, Mrs. Douglas not only understands her husband's sarcastic comments but also consistently defends her position. For example, when Mr. Douglas points out her lack of benevolence toward her neighbors, Mrs. Douglas quickly retorts, “I don't set up for that sort of character, because I happen to see things as they are, and I am never taken in by the cant of prosperity, and that sort of pretension" (46). Mrs. Douglas prides herself on her astuteness and, as I argue in the 
case of her criticism of Lord Teviot, her nasty tongue can also contain truth and insightfulness.

Despite the fact that Mr. Douglas married her for her money, rather than for love, he has been to her "what is called a good husband" (21). According to the narrator, he is a good husband in that, he let her have a reasonable portion of her own money, he abstained from all vivid admiration of beauty within her hearing; he had a great reliance on her judgment and a high opinion of her talents... He heard with pain her sarcasms on almost all her acquaintance, he seldom irritated her by contradiction, but kept his own opinion with a quiet regret that his wife was so hard to please (21).

Despite his occasional ironic comments, her husband generally accommodates and gives into her wishes. Realizing her jealousy of other women's looks, he refrains from praising any women's beauty in front of her. More importantly, he appreciates her talents and relies on her judgements.

Mr. Douglas also stands by silently while his wife speaks for herself and often for the family as a whole. He may regret her sharp tongue, but he does nothing to contain it. He expresses his irony only in private; he pacifies his wife by not correcting her in public or expressing any alternative opinions. Although Mrs. Douglas does not, like Lady Olivia, manage the family finances, her voice is the dominant voice inside and outside the home. In contrast, Mr. Douglas accommodates her, keeping his own opinion to himself. Also, she does make decisions for Mr. Douglas as well as for 
herself and her daughters. When he is asked to run for parliament, for example, he dislikes the idea and is ready to turn down the offer until Mrs. Douglas pressures him into it. In a more traditional marriage, Mr. Douglas would not keep his opinions to himself and would not allow Mrs. Douglas free reign to speak for the family. Instead he would exert dominance and correct her, not just in ironic asides, but more authoritatively. Similarly, he would abide by his own distaste for campaigning for parliament rather than allowing her to direct his decision. The Douglas marriage, therefore, is in many ways not a traditional nineteenth-century marriage. Mrs. Douglas, through her grotesqueness, her dominance over her husband, her controlling nature, and her excessive talkativeness, inverts gender roles in her marriage and thus challenges cultural assumptions surrounding a wife's quietness and submissiveness.

Mrs. Douglas, as I have said, provides much of the comic relief in the novel. She is constantly mocked by the narrator and occasionally by the other characters as well. The initial description of Mrs. Douglas' character is harshly satirical, she "was excessively plain...and had a soreness on the subject of beauty, that looked perhaps as like envy as any other quality...for real genuine, hard-working envy there is nothing like an ugly woman with a taste for admiration. Her mortified vanity curdles into malevolence; and she calumniates where she cannot rival" (21). From the beginning, therefore, the reader understands that jealousy and vanity are at the center of her nastiness. Further, the narrator mocks Mrs. Douglas' hesitation to vary from her negativity and nastiness by expressing a positive opinion of another character. For 
example, when Mrs. Douglas feels pleased with Mary Forrester as a guest, the narrator states, "though it would have made a sad break in her habits to acknowledge it" (197). Unlike Lady Olivia in Pin Money, however, Mrs. Douglas shows the ability to laugh at herself. On one occasion, Helen has taken special care to dress well for her first appearance as Lady Teviot before the local townspeople at a political event. Lady Portmore, jealous over Helen's beauty and position, chimes in that her appearance was also appreciated by the crowd, saying "And mine," referring to her own beauty (156). Mrs. Douglas quickly rejoins, "And mine...in a tone that made everyone laugh" (156). Mrs. Douglas not only mocks Lady Portmore with this rejoinder but also has a sense of humor about herself and her own plain appearance. The double nature of the comedy surrounding Mrs. Douglas - where she is both mocked by the narrator and able to laugh at herself and at cultural mores - is reminiscent of Bakhtin's carnival laughter.

As I discussed in Chapter One, Bakhtin's description of carnival laughter evokes a more complex laughter than simply one of derision toward a specific person or an isolated comic event. Festive laughter acts to expose the supposed naturalness of the social order as artificial and thus unveils the truth about the world. The demystification found in laughter is brought about by carnival imagery, usually grotesque imagery, which holds up "emblems of power and authority as objects of derision" (Bakhtin 94). Similarly, the humor of The Semi-Attached Couple does not depend solely on designating a character like Mrs. Douglas as the object of mockery. The reader instead is encouraged to find humor in this grotesque character's own 
amusement around their faults and the faults of those around them. More importantly, her outspokenness and mockery of marital relationships lead the reader to question nineteenth century ideals surrounding romantic marriage.

Just as the humor surrounding her is complex, Mrs. Douglas is a more complex character than her sharp tongue may at first reveal. Despite Mrs. Douglas' nasty outspokenness throughout the novel, she is not wholly negative and critical. She has a soft side especially for babies, Helen Beaufort, and her daughters. When Eliza Douglas is invited to visit Eskdale Castle, Mrs. Douglas is so grateful for the invitation that she disappoints her neighbor who comes to visit "armed with some little antiEskdale anecdotes and a small supply of malevolence" (83). In her brief foray into benevolence, Mrs. Douglas refuses to engage in ill-natured gossip (83). She consistently has a soft spot for Helen so that Helen is the only member of the Beaufort family Mrs. Douglas hesitates to criticize. Her soft side and her ultimate taming by her son-in-law, Colonel Beaufort, render Mrs. Douglas a well-rounded character.

At the end of The Semi-Attached Couple, Mrs. Douglas is in a state of intense felicity at the engagement of her daughter, Eliza Douglas, to Colonel Beaufort, a cousin of the Beauforts at Eskdale Castle. The insouciant Colonel Beaufort, during a visit with the Douglas family, has a habit of keeping the surface smooth and announcing his intentions with perfect assurance that they will be carried out. Mrs. Douglas, at first puzzled by the novelty of his "gentleman-like selfishness," gradually becomes interested in pleasing him, and feels a "degree of pride in seeing a man of 
such fastidious habits and manners perfectly happy" at the Douglas home (284). He gently ignores her loud spoken complaints about the servants and neighbors, and this serves to check her more effectively than an argument or contradiction would have done. Further "he was so naturally courteous that she found herself treated with a degree of easy kindness which few people had ever ventured to show her. It tamed her" (284). Under Col. Beaufort's influence, she ceases to be "rough" and, adopting his refinement, begins to behave according to Col. Beaufort's "habit of keeping the surface smooth" (284). The end of the novel shows Mrs. Douglas attending the double wedding of her daughter and Col. Beaufort at Eskdale Castle without verbalizing her usual excessive list of grievances. The narrator gently mocks her silence and her enjoyment of the wedding and her fellow guests. Interestingly, the grotesque shrew, Mrs. Douglas, is tamed by the end of the novel; Eden even uses this term.

It is unclear, however, whether Mrs. Douglas' shrewishness is tamed only in her behavior toward Col. Beaufort or whether she will refrain entirely from all her nasty gossip and complaints. Will she adopt a quieter persona as well as a more traditional role as a wife? If so, the gender inversion demonstrated by the Douglas marriage will prove temporary, just as the inversions in Bakhtin's theory of carnival were temporary, as part of a limited time of free play. Whether temporary or permanent, Mrs. Douglas' gender inversion gives readers a glimpse of the possibility of a marriage that differs from a traditional, male-dominated marriage. In this marriage Mrs. Douglas speaks independently, albeit nastily, and argues with her husband 
freely and successfully. Mr. Douglas, despite often disagreeing with her, gives way to her opinions and desires. He strives to make her happy while she opposes him without hesitation. Mrs. Douglas, therefore, expands her role outside the cultural norm of a silent and submissive wife striving to make her husband happy. Her grotesque qualities - especially her sharp tongue, normally disadvantages, afford her the ability to achieve some measure of independence and control in her marriage.

\section{Lady Portmore}

Like Lady Olivia and Mrs. Douglas, Lady Portmore is grotesque through her behavior-she talks incessantly and makes a spectacle of herself. She often dominates conversations by entering into verbose explanations to justify her own opinions. She displays little sensitivity as to how others react to her speeches. In fact, the narrator reports that Lady Portmore hasn't a grain of tact, "a misfortune that fell more heavily on her friends than on herself" (113). Lady Portmore is also a notorious gossip both within upper-class society and, more specifically, at the Teviots' house party. Every morning she lingers over breakfast after the other ladies have left the table and gossips with the men. Much of her gossip focuses on herself and her belief that several men are in love with her.

In addition, Lady Portmore, like Lady Olivia, tries to control those around her through her constant talking. Lady Portmore acts most improperly by receiving guests and behaving as though she, rather than Helen, is mistress of the house. In addition, Lady Portmore often attempts to redirect and control the other guests' activities whenever she is displeased with the arrangements. For example, when she 
observes Col. Beaufort sitting with Eliza Douglas, out of jealousy she bustles over and asks Eliza to play the piano. While Lady Portmore is motivated only by pursuit of her own interests, in this case establishing Col. Beaufort as her own love interest, her attempts often "disturb the general comfort of the society" (125). She not only interferes with Helen's plans for her guests, but she also assumes an air of superiority, implying that Helen is not skilled as a hostess and should therefore rely on Lady Portmore's unsolicited advice.

Lady Portmore not only presents herself as a perfect hostess but also boasts, absurdly, of her expertise in every area. The narrator states, that because of her "restless vanity" she believed, she was the world's universal confidante and she would enter into long arguments to prove that she must necessarily have foreknown any piece of intelligence or gossip...Like all very vain people, she was contradictory; and this, added to her pretensions to universal knowledge, rendered her conversation a glorious mass of inconsistencies (110).

At one point, Lady Portmore claims responsibility for all the political changes of the past year and that she knows "all that were likely to take place in the ensuing one" (92). When she learns of Lord Teviot's diplomatic mission to Lisbon, she is "in her greatest glory, and unusually overpowering" as she attempts to control the conversation and his travel arrangements (175). The quality of her advice is questionable as she must first be rescued from her confusion between Spain and 
Portugal. Because Helen is not traveling to Lisbon, Lady Portmore suggests that her husband "run over there in his yacht, that she might assist Lord Teviot" in his diplomatic mission (175). Her excessive talkativeness as well as her propensity to draw attention to herself renders her grotesque.

Just as her vanity leads her to believe she is an expert in a wide variety of fields, it also causes her to fancy that both Lord Teviot and Colonel Beaufort are in love with her, despite clear evidence to the contrary. She claims that before his marriage, Teviot spent so much time at her house, it was "literally his home" and he was on the same footing as a family member (89). She visits the Teviots ostensibly so that "there should be no awkwardness, no coolness between us" (90-91). Despite her declared intention to avoid awkwardness, Lady Portmore continues to pursue the married Lord Teviot by maneuvering him into accompanying her on long carriage rides and walks separate from the rest of the company. While alone with him, she speaks persuasively and confidently about Helen's feelings and she convinces Lord Teviot that his wife is not in love with him. Further, she strives to prevent the couple from spending any time together by talking incessantly to Lord Teviot. The narrator encourages the reader's ambivalent feelings toward this character by presenting her as a danger to the Teviot's happiness; additionally, she is portrayed as a comic grotesque through her vanity and talkativeness.

Due to her "restless vanity," Lady Portmore also insists that Colonel Beaufort is in love with her. She speaks openly and incessantly about how Ernst (Col Beaufort) constantly calls on her in London and insists that Ernst is "desperately smitten" with 
her (100). Col. Beaufort, however, does not take her seriously despite her persistence. When she tells the company that she forbade Col. Beaufort from following her to St. Mary's, he jokes that he would dislike following her as he would be smothered by the dusty roads. Oblivious to his humor, Lady Portmore continues to insist he is in love with her and, when he spends time in conversation with Eliza Douglas, she attempts to separate them by asking Eliza to play the piano. She even attempts to persuade Mrs. Douglas to protect her daughter from Col. Beaufort, claiming Beaufort is already in love with a married woman, presumably her. Despite her efforts, Col. Beaufort never takes her seriously and, in the end, marries Eliza. Similarly, Lord Teviot and Helen reconcile; Lord Teviot realizes that Helen is in love with him and, therefore, that Lady Portmore's so-called superior knowledge of Helen's feelings is false. Although Lady Portmore has a persuasive tongue, neither her rhetoric nor her beauty proves more than temporarily successful with either of her chosen victims.

Lady Portmore is, unsurprisingly, cynical about upper-class marriage. In this respect, she is similar to Lady Olivia, who views marriage as a business contract, and to Mrs. Douglas, who views the marriage vows with suspicion. Although she claims to enjoy nothing better than a long evening at home with her husband, she must attend social engagements because, "other people must be considered-the people who invite one to their houses - and one must go, for fear of not being asked again; and that is the rock on which my domestic happiness splits" (88-89). Her desire for domestic happiness seems dubious when the reader considers her flirtatiousness 
with Lord Teviot and Col. Beaufort. She predicts Helen will make the same choice to put social obligations ahead of her husband, for "if she stays at home, what becomes of her position, and her rank...[and] you forget her diamonds." According to Susan Fellows, Eden created Lady Portmore's character to show the "cruel, unethical behavior of those in upper social echelon" and to censure the "commodification of marriage" (112). Lady Portmore's attitude toward married life and her interest in other men represents an extreme cynicism toward love and fidelity in marriage. Her cynicism toward marriage, like that of Mrs. Douglas, points to the false ideals of romantic marriage.

Although the male guests enjoy her company, her grotesque qualities--her excessive and controlling talkativeness as well as her immorality--lead "all [the] women [to] hate her" (93). Eliza Douglas dislikes her officiousness as she acts as though she is the mistress of the Teviots' house. Because she doesn't find fault with any of the other assorted characters at the house party, Eliza's opinion is rather persuasive. Mrs. Douglas, as is her wont, dislikes Lady Portmore immediately, saying that she finds her a "beauty and a fine lady" but "perfectly insupportable" so that it would be a "virtuous action to be as disagreeable as possible to her" (121). The middle class Mrs. Douglas finds Lady Portmore's arrogance about her male admirers a sign of her upper-class immodesty and immorality. Helen finds Lady Portmore unpleasant and a constant threat to her marriage. On one occasion, Lady Portmore speaks to Helen privately in order to give Helen advice about managing Lord Teviot; she inappropriately suggests that she possesses intimate knowledge about him. After 
Lady Portmore leaves the room, Helen throws the windows wide open, thinking "nothing short of a thorough draught could drive Lady Portmore's conversation out of the room" (103). Lady Portmore's grotesque talkativeness poisons the very air. Although Mrs. Douglas and Lady Olivia Tadcaster share Lady Portmore's cynicism about marriage, their attitudes, unlike Lady Portmore's, do not lead to improper behavior or sexually suggestive language. Lady Portmore, on the other hand, behaves and talks quite improperly by pursuing admirers outside her marriage and openly criticizing her husband. Her behavior and flirtatious language with men suggest an unruly woman who is not only excessively talkative but also sexually inappropriate. In fact, the shrewish female is often associated with wantonness, thus she transgresses cultural norms in two different ways. ${ }^{34}$ In her study of texts from Biblical through modern literature, Patricia Parker finds the "misogynist topos of women's endless talkativeness" has its counterpart in a "vagrant female sexuality" (3). Female speech, Parker argues, is often linked with "unbridled sexuality" and both are "ranged against Obedience" (26). Parker notes the relationship between a potentially uncontrollable female sexuality, a woman speaking in public, and a woman usurping her proper place (106). Patricia Parker discusses the function of the extravagantly "talkative harlot" as "the influential monitory antitypes to the shamefast and silent woman,

\footnotetext{
34 This connection between a shrewish mouth and sexuality is found historically. According to Margaret Miles, the association of "garrulousness with wantonness was part of a well-established polemic" against women across many societies of the Christian west (99). Legislators of social order in the sixteenth and seventeenth centuries believed a "woman's tongue, like her body, must be strictly governed," because unrestricted speech is the surest sign of a woman who is "sexually loose" (Miles 108). A fifteenth-century treatise by Francesco Barbaro, On Wifely Duties, warns that "the speech of a noble woman can be no less dangerous than the nakedness of her limbs (Stallybrass 127). Davis, studying Medieval and Renaissance fairs, finds that the "voracious and shrewish female mouth is a more generalized version of the more ambivalently conceived female orifice, the vagina" (37).
} 
modestly observing her proper place and moving within a circumscribed sphere" (107). Lady Portmore definitely does not keep to her proper place as a loving, obedient wife as she gathers admirers and speaks excessively and improperly. Her unruliness could certainly stand as an admonition to a properly silent woman.

Although we never see any interaction between Lord and Lady Portmore, we know, based on her flirtations with gentlemen callers and her pursuit of Lord Teviot, that she does not treat Lord Portmore with respect. According to a former servant, Lady Portmore "has no more respect for Lord P than she has for the hearth-broom; and all she is at from morning to night [is] to catch up admirers" (109-10). In another example of disloyal behavior, Lady Portmore complains to Lord Teviot about her husband launching "into a sea of all poor Lord Portmore's little stupidities, with which every one of her male friends were indulged in their turn" (186). Apparently, Lady Portmore entertains all her gentlemen callers by mocking her husband's idiosyncrasies. Beyond this reference to his "little stupidities" the reader actually knows very little about Lord Portmore except that he apparently tolerated Lord Teviot's constant presence with Lady Portmore before his marriage. The novel itself, in fact, as well as Lady Portmore, treats him as a non-entity. Although he is present at the house party, he never has a speaking line or an appearance in any scene. For example, when Lady Portmore gossips with the gentlemen at breakfast, it is unclear whether he is a member of this breakfast club. Also, when Lady Portmore takes frequent drives and walks with Lord Teviot, the reader never hears of Lord Portmore's reaction or about his own activities. Aside from her complaints about 
him, Lady Portmore only refers to him when she speculates about having him sail her in his yacht to Lisbon to be with Lord Teviot. A form of gender inversion is enacted by this erasure of Lord Portmore from the text, a disappearance which gives Lady Portmore the power to engage in romantic intrigues outside her marriage. Although her attempts to engage Lord Teviot and Col. Beaufort are ultimately unsuccessful, as the novel closes Eden hints that Lady Portmore will continue her extramarital affairs. As a comic grotesque, unruly woman, Lady Portmore challenges male authority and demonstrates to the reader an example of expanding a woman's behavior beyond her traditional feminine role of submitting to her husband's will.

\section{Mrs. Douglas \& Lady Portmore at War}

As I discussed earlier, Mrs. Douglas finds Lady Portmore "perfectly insupportable" and thinks it a virtue to be as disagreeable as possible towards her. She gets an opportunity in a very amusing scene in which the two women face off in a battle between upper and middle-class values. Their conversation starts with Lady Portmore warning Mrs. Douglas about Col. Beaufort's attentions toward Eliza. He is not serious, she argues, because he is very much "in love with-a married woman" (129). Although Lady Portmore refers to herself, she does not openly admit that she is the married woman. Their debate soon turns to the so-called difficulties of an upper-class, married woman with male admirers, with Lady Portmore arguing that this situation is difficult for a loyal wife to handle. Mrs. Douglas, however, has no sympathy for "married women and their lovers" saying it is the woman's fault and "it gives me the worst possible opinion of her" (129). Lady Portmore then tells the story 
of a married woman who travelled to Cornwall to get away from a determined man. Mrs. Douglas retorts that when she hears of the difficult position of a married woman with her lovers, she thinks her a "good-for-nothing woman" (129). When Lady Portmore protests, Mrs. Douglas holds her ground saying, "She is certainly not a good wife, nor probably a good mother, and certainly not a good Christian" (129). Lady Portmore tries to argue that if Mrs. Douglas lived in London, presumably among the upper classes, she would see how difficult it is for a woman to avoid admirers. As Susan Fellows theorizes, Eden exposes the hypocrisy within the upper class through Lady Portmore's argument over the difficulties of a married woman with lovers. Seeing Mrs. Douglas is unconvinced, Lady Portmore claims to be "just like you, one of the strictest people possible, excessively straitlaced in all matters of principle" (129). After observing Lady Portmore's behavior and speech, it is difficult for the reader or Mrs. Douglas to give this claim any merit.

Next, Mrs. Douglas, in an apparent change of subject, makes the debate more personal. She asks, "with an innocent air of doubt," if Lady Portmore has any grownup daughters (130). Flustered at this aspersion on her age, Lady Portmore protests that she has only been married nine or ten years. Moreover, she was, "quite a child at the time; married literally from the school-room" (130). Mrs. Douglas then points out that there is no one at the house party to amuse Col. Beaufort but Eliza. She continues, "apparently he has not the slightest taste for our society" (130). She implies, of course, that both she and Lady Portmore are too old to attract Col. Beaufort. After this thrust, Lady Portmore is "regularly out of sorts and in that soured 
state in which the wish to do a little mischief is a consoling idea" (130). She thinks about leaving St. Mary's but, although Col. Beaufort's affection might be unattainable, "her faith in her power over Lord Teviot remained unshaken" (130). Although she never wins Lord Teviot, Lady Portmore continues to stay at St. Mary's until the house party breaks up. On the day of Mrs. Douglas' departure, Lady Portmore emphasizes her upper-class status by assuring the Douglas family that "they would not find her one of those odious fine ladies who would cut them if ever they came to town" (191). Unsurprisingly, this "last touch of grandeur" makes Mrs. Douglas very angry and redoubles her dislike of Lady Portmore (191).

Despite their mutual dislike, both of these comic grotesque characters have several qualities in common. Because of their loquaciousness, they are disliked by many other characters. Mrs. Douglas is generally resented for her nastiness as she gossips about her negative opinions of everything and everyone; Lady Portmore, on the other hand, is disliked by the female characters as she brags about herself as an object of male adoration and constantly flirts with the male characters. Both characters dominate other characters through their garrulousness and they selfishly steer the conversation toward their own interests. In fact, despite their status as secondary characters, both Mrs. Douglas and Lady Portmore through their speech take up a disproportionate share of the novel; they dominate every scene in which they appear. Mrs. Douglas' role is, in fact, highlighted by Eden as the novel begins and ends with Mrs. Douglas as the focal point. 
Most importantly, both unruly women subjugate their husbands, although in different ways, and thus perform gender inversions. Mr. Douglas gives his wife full reign to speak and act as she likes. He also follows her advice even when it differs from his own opinions and preferences. When he does speak up about her negativity or hypocrisy, Mrs. Douglas quickly dismisses his opinion and strengthens her argument. Lord Portmore, on the other hand, is practically erased from his marriage and from the novel. Lady Portmore constantly seeks male admiration outside her marriage without his protest or interference. She also speaks of his character dismissively to her potential lovers. Although Lord Portmore accompanies her to the house party at St. Mary's, Lord Portmore never speaks and never appears in a scene. Davis, in her study of Renaissance literature, points to husband dominators everywhere in popular literature. She describes these women as "funny and amoral; ...full of life and energy and they win much of the time" (134). Mrs. Douglas and Lady Portmore, characters in popular literature, reflect Davis' description; they are funny, full of life and they win much of the time by dominating their husbands. While Lady Portmore is definitely immoral, Mrs. Douglas displays a strict middle-class morality. In both cases, they challenge male authority figures and demonstrate to the reader the possibility of expanding their behavior beyond traditional feminine roles.

\section{Conclusion}

All three characters, Lady Olivia Tadcaster, Mrs. Douglas, and Lady Portmore are excessively talkative, shrewish gossips and invert gender roles with the men in their lives--Lady Olivia with her nephew and Mrs. Douglas and Lady Portmore with their 
husbands. They also dominate conversations and scenes, taking up a relatively large proportion of the novels. Their garrulous presence in the novels reflects Patricia Parker's study, Literary Fat Ladies, which theorizes the alignment between "female loquacity with fatty texts" in certain Post-Renaissance literature (32). Parker identifies female figures who lead to an "extension or dilation of text to defer its end of point" (13). The control of female speech, therefore, brings "shaping and closure to the potentially endless movement of dilation" (26). Kathleen Rowe sees Parker's fat text as a feminized talky text that is "both pleasurable and dangerously resistant to proper restraint" (1995 37). This fat text, like the loquacious female behind it, represents a challenge to the text's ability to come to a point as well as to the need to "master or contain such feminine mouthing" (Parker 26). In these two novels, the three loquacious females are not contained and therefore they have the power to dominate relatively large sections of the text.

Lady Olivia, Mrs. Douglas and Lady Portmore also resemble the 'women on top' theorized by Davis' study of Medieval and Renaissance festivals. A domineering wife, according to Davis, frequently participated in a Skimmington ride during which she beat her henpecked husband with a skimming ladle. Although the nineteenthcentury version of the woman on top does not actually beat her husband with a skimming ladle, she is, like her Renaissance counterpart, "shameful, outrageous, [and] also vigorous and in command" of the men in her life (Davis 140). As I have shown, these three characters exhibit outrageous and controlling behaviors through their loquacity. A woman talking excessively is a transgressive behavior for which 
women are both criticized and mocked. For example, conduct literature of the late eighteenth and early nineteenth centuries warns that a talkative woman will not make a good wife. Further, shrewish women are the objective of derisive humor. These comic grotesque women, although they are objects of amusement, are not punished for their behavior. Instead, they turn a disadvantage into an advantage by using their talkativeness to invert gender roles, thereby achieving some measure of authority over the men in their lives.

This inversion of gender roles leads to Lady Olivia's assumption of her nephew's financial affairs and Mrs. Douglas' and Lady Portmore's subjugation of their husbands. Through these gender inversions, they challenge male authority and prompt new ways of thinking about the traditional gender hierarchy. Neither Pin Money nor The Semi-Attached Couple advocate transgressive female behavior through the main plots or through the heroines in either novel. In fact, the heroines in both novels model normative gender hierarchy through their enactment of loving, submissive wives. Through these comedic secondary characters, however, Gore and Eden are able to explore possibilities which diverge from nineteenth-century patriarchal authority and gender conformity and so challenge socio-cultural norms. 


\section{CHAPTER 4}

\section{Comic Grotesque as Picaresque Heroine}

In Chapter Four I analyze the comic grotesque character, Martha Barnaby, from Frances Trollope's Widow Barnaby trilogy. The Widow Barnaby is grotesque in both her appearance and her behavior. Like Mrs. Hopkinson and Mrs. Musgrove in The Semi-Detached House and Persuasion respectively, as I discussed in Chapter 2, she is quite corpulent; her appearance is linked to her vulgarity and lower class status. In addition, like Lady Olivia Tadcaster from Pin Money and Mrs. Douglas and Lady Portmore in The Semi-Attached Couple, Martha Barnaby has a talkative and controlling nature. Further, she draws attention to herself not only through her corpulence and garrulousness but through her ostentatious dress and excessive application of cosmetics. Martha Barnaby is the epitome of a female spectacle as described by Mary Russo, a woman who transgresses norms through her appearance and/or behavior. Martha Barnaby not only transgresses norms but, through these transgressions, she provides a potentially subversive alternative to the ideal nineteenth-century woman.

In the texts I analyzed in Chapters Two and Three, the female comic grotesque characters are secondary characters in their respective novels. The effect of their gender/class inversions and their liminality, therefore, remains subtle because of their relatively minor roles in the novels. In Frances Trollope's Widow Barnaby trilogy, however, the comic grotesque character, Martha Barnaby, is the main character of the series, and thus the effect of these inversions and liminality are 
greater. In addition, while the gender and class inversions in the previous novels were temporary, the gender inversion whereby the Widow Barnaby becomes the superior partner in her marriage to Major Allen appears permanent. The unruly Widow Barnaby, therefore, is a more formidable challenge to nineteenth-century domestic ideology.

In this chapter I begin with a summary of Frances Trollope's life and writing career. Next, I provide a brief synopsis of each novel in the Widow Barnaby trilogy. I follow with an analysis of the Widow Barnaby's grotesque qualities which are rooted both in her appearance and her behavior as well as how she operates as a spectacle within the novels. I argue that these qualities along with the gender and class inversions they invoke, facilitate the character's challenges to cultural norms. More specifically, I examine Martha Barnaby's two-novel long power struggle with her husband as well as the trilogy's satirical representation of marriage. I then analyze Martha Barnaby as a picaresque character and the significance of the picaresque with gender and class inversions. Finally, I compare her character and its potential subversiveness with the grotesque characters from Chapters Two and Three.

\section{Frances Trollope}

Frances Milton Trollope was born in 1779, the third daughter of a clergyman in Heckfield, Hampshire. She was a contemporary of Jane Austen, born 1775, and coincidently also the daughter of a clergyman. Unlike Austen, however, Trollope did not begin her writing career until later in life when she was over fifty. Like Catherine Gore, Trollope wrote primarily, and prolifically, to support her family. Her novels 
encompass a variety of subgenres including social problem novels, an anti-slavery novel, and satirically comic novels. Her most successful novels were The Widow Barnaby (1839) and its sequel The Widow Married (1840). Similarly, the eponymous Martha Barnaby was Frances Trollope's most popular character. Many of her female characters, including the Widow Barnaby, were strong, vibrant, and independent women.

\section{Trilogy Synopsis}

The Widow Barnaby (1839), the first novel in the trilogy, follows the adventures of the thirty-something Martha (Compton) Barnaby and her search for a wealthy, upper-class second husband after the death of her first husband, Mr. Barnaby, the local apothecary. The importance of and acquisition of a higher class status is prominent from the beginning of The Widow Barnaby and this theme continues throughout the trilogy. Mr. Barnaby has left her in sole control of a comfortable income of 400 pounds per year. After a scant three months of mourning, the Widow Barnaby sets off, accompanied by her sixteen-year old, orphaned niece, in pursuit of a second, more upper-class husband. During her travels to Clifton, Cheltenham and London, she poses as a lady of great fortune as part of implementing her strategy to attract a greater fortune. She also leaves behind her mourning clothes for more colorful and attention-getting attire.

In Clifton, she enters into a promising romance with Major Allen but this fails when both parties discover the other has exaggerated about their financial and social status. In Cheltenham, she dreams of becoming a Viscountess when Lord Mucklebury 
flirts and exchanges romantic letters with her, but then she discovers that he has no serious intentions towards her. She then neglects to pay her bills before leaving Cheltenham for London, so her creditors follow her to London and have her thrown in debtor's prison. There she meets the young (ten years younger than Martha), handsome adventurer, Rev. O'Donagough, the illegitimate son of an earl, who promises both Martha and his father that he will reform by becoming a missionary in Australia. Unfortunately, his reformation does not last long, as he resumes gambling shortly after their marriage and is actually killed while participating in a horse race he had bet on. At the end of the novel, the Widow Barnaby ${ }^{35}$ meets Major Allen again and marries him, allowing her affection to overpower all her doubts about him.

The novel also contains a significant secondary plot revolving around her niece Agnes Willoughby, the daughter of the Widow's deceased sister, who accompanies the Widow on her travels and acts as both her companion and maid. Ironically, Agnes achieves the upper-class marriage the Widow seeks as by her marriage to Col. Hubert, a wealthy army officer. The Agnes plotline, in which she marries for love, serves as a distinct contrast to the Widow's search for wealth and social status in marriage. Agnes herself, with her pale and ladylike appearance in mourning clothes and her demure character, also provides a constant contrast with the Widow's

\footnotetext{
35 I refer to Martha (Compton) Barnaby O'Donagough Allen as the Widow Barnaby or the Widow throughout this chapter for two reasons. The first is to remain consistent with her designation as the Widow Barnaby in the titles of Trollope's trilogy. The second is for simplicity as this character is alternatively known as Martha Compton, Martha Barnaby, Martha Allen, Martha O'Donagough, and finally Martha Barnaby again as she both remarries and travels with her third husband, Major Allen, under false names. Similarly, I refer to Major Allen as the Major throughout rather than by his aliases: O'Donagough and Barnaby.
} 
flamboyance and vulgarity which serves to emphasize the Widow's grotesque qualities.

The second novel in the trilogy, The Widow Married: A Sequel to The Widow Barnaby (1840), follows Martha Barnaby's continuing efforts to enrich herself and Major Allen, her third husband, and to achieve an advantageous marriage for their daughter Martha, usually referred to as Patty. The family travels from Australia to England and reestablishes contact with Agnes, now married to General Hubert. The Widow hopes they will help introduce Patty into upper-class society so she will marry well. Major Allen, an expert at card sharking, plans to increase his profits by cheating wealthy and naïve aristocrats in England. Because he is already known in England as a swindler, Major Allen changes his name to Rev. Allen O'Donagough, combining his last name with that of the Widow's second husband. In addition, he disguises himself as a clergyman by shaving his luxuriant whiskers and adopting more sober attire. The Widow calls him Donny while Allen refers to her as "his Barnaby."

After a few months of interactions with the O'Donagoughs, the Huberts, finding their coarseness and vulgarity difficult to endure, depart on a protracted trip to the Continent. Over the next two years, during the Huberts' absence, the O'Donagoughs move to London and Allen O'Donagough makes a great deal of money cheating at cards. They live in a mansion and socialize with people elevated in society, at least those interested in playing cards for high stakes. When the Huberts return, the Widow arranges to present Patty at court on the same day as Agnes' daughter, Elizabeth. On that same evening, during a party at the O'Donagough house, Allen is 
caught cheating at cards. General Hubert persuades him to leave the country to avoid prosecution. In another plot twist, Patty elopes with the black-whiskered Don Espartero Tornorino, an impoverished Spaniard she met at the modest boarding house where they initially lived in London before they moved to their mansion.

The Barnabys in America or Adventures of the Widow Wedded (1843), the final novel in the trilogy, portrays the Barnaby family's adventures in America where they flee after Major Allen is caught cheating at cards at the end of the last book. Major Allen, without fully explaining, declares it is best not to appear in America under either of his former names so he decides they will assume the names Major and Mrs. Allen Barnaby as a compliment to his wife. In America, they engage in several getrich-quick schemes, adapting themselves to the habits and attitudes of each geographic location they visit. First, the Widow masquerades as a famous author from England who is writing a travel book about America. She proposes to write in praise of slavery to the plantation owners in New Orleans. Later, to the Quakers in Philadelphia, she proposes a book criticizing the evils of slavery. In the meantime, Major Allen earns money cheating at cards and engaging in fraud. Because he repeatedly falls under suspicion for his schemes, they must flee New Orleans, Philadelphia and New York to escape apprehension. Each time the Widow craftily plans their successful escapes. The novel and the trilogy ends with their return to Europe ostensibly to continue their nefarious adventures.

Grotesque Qualities of the Widow 
As I discussed in Chapter 1, an important quality of the grotesque is the mixed emotional reaction a grotesque character produces in the reader. Thus, readers experience horror or disgust and amusement at the same time. Phillip Thomson, for example, argues that a basic quality of the grotesque is its creation of a paradox of attraction and repulsion. Similarly, contemporary reviewers of the trilogy identify this mixed emotional reaction, or paradox, aroused by Trollope's creation of this appealing rogue character. For example, an unsigned review in the London Times ${ }^{36}$ praised the originality of Trollope's conception, which made the reader's enjoyment somewhat paradoxical and puzzling: "The Barnaby is such a heroine as never before has figured in a romance. Her vulgarity is sublime." The reviewer also referred to the "charming horror" that had carried him through the volumes: "such a jovial, handsome, hideous, ogling, bustling monster of a woman as maid, wife, and widow was never, as we can recollect, before brought upon the scene...amiably disagreeable, more delightfully disgusting than the Widow Barnaby." The combination of contradictory terms like "amiably disagreeable" and "delightfully disgusting" delineate the uncomfortable sense of irreconcilable reactions--both repulsion and the attraction--the reviewer felt for this character. This paradoxical and unresolved response toward a character is the very definition of the grotesque.

The Widow displays a combination of so many grotesque qualities that she is the very quintessence of the grotesque. She talks incessantly like Lady Olivia Tadcaster of Pin Money and Lady Portmore and Mrs. Douglas of The Semi-Attached Couple. Her

\footnotetext{
3624 January 1839.
} 
corpulence rivals that of Mrs. Musgrove of Persuasion and Mrs. Hopkinson of The Semi-Detached House. Her flamboyant dress and overly enthusiastic application of rouge add to her grotesque vulgarity. In fact, through both behavior and appearance, the Widow constantly makes a spectacle of herself. In the following section, I explore how each of her grotesque qualities operates as both a source of amusement and repulsion. Then, I argue that her grotesqueness gives the Widow the opportunity to achieve a class inversion through her representations of herself as an upper-class lady and a gender inversion through her successful power struggle with her husband.

One of the Widow's most prominent characteristics in the trilogy is her excessive talkativeness. As I described in Chapter 3, a nineteenth-century garrulous woman is grotesque because she is loud, shrewish, and threatening to social and political structures. The Widow Barnaby, talkative throughout the trilogy, demonstrates her ability to shape her speech to the particular situation she creates in each novel. In The Widow Barnaby, when visiting her sister-in-law in Clifton, the Widow, in trying to please Mrs. Peters, speaks continuously and in deceptively philosophical tones of her intention to leave her fortune to the Peters children. This produces an unintentional result, as Mrs. Peters wishes the Widow will move speedily out of their house and into lodgings because she is "worn to a thread by listening to [her] noble sentiments" (Vol. 1, Ch. 15). The Widow also chatters flirtatiously and laughs disproportionately when in the company of eligible men. She draws attention to herself out of her conviction that "an animated expression of countenance and a great vivacity of manner would turn a young man's head than all the mere beauty in the world" (WB, 
Vol. 2, Ch I). At a ball, for example, instead of behaving like a bereaved widow, "her joyous laugh and her conscious whisper... attracted attention from all around" and she is "loud in voice with a loud laugh" (WB, Vol. 2, Ch II). She displays no modesty; any attention encourages her, as "the more she is looked at, the more the Widow talks and laughs" (Vol 2, Ch. XIII). While she employs her "great vivacity" to attract male admiration, once she has remarried, she continues her talkativeness.

In The Widow Married, the Widow now uses her garrulousness not for flirtation but in her arguments with her husband. In an argument over the disposal of their luggage during their trip from Australia to England, Trollope refers to the Widow's "rebukes and scoffings" and her "conjugal vivacities" to describe the "audacious vigor" of her mind (WR, Ch. VIII). She is also overpowering when initially calling on her niece's family, the Huberts, after her return to England. Her "energetic affection" causes her to laugh ecstatically at their reunion and then weep as she recounts days gone by (WM, Ch. XVII). When she visits Mr. Willoughby, her brother-in-law, her talkativeness so overwhelms and fatigues him that he retires to his room.

Throughout this section of the novel, Trollope repeatedly and amusingly refers to Mr. Willoughby's failing health and subsequent frailty, both occasioned by the Widow's frequent and excessively talkative visits.

In The Barnabys in America, the narrator points out that the Widow is, in general, more of a talker than a listener. The Widow listens enough, however, to figure out her victims attitudes so that her own talk is quite persuasive as well as excessive. Through her numerous stories about appearances at court (and a display of her 
luxurious clothing), she persuades the New Orleans group that she is of the upper classes. She has the ability, for example, to persuade slaveowners that she is a renowned author as well as an advocate for slavery. She keeps her audience spellbound as she reads from the supposed first chapter of her book. In Philadelphia, just as she did in New Orleans, she convinces the Quakers in her boardinghouse that she is a great author. This time, however, she claims her ambition is to write an antislavery book. She spins a tale about Major Allen's putative desire to squash her endeavor and swindles them out of $\$ 500$ to support her writing. Her ability to spin a deceptive tale and adapt her persona for her audience demonstrates her cleverness. In fact, the narrator and the characters in The Barnabys in America frequently refer to the extraordinary acuteness of her mind. In the first two novels, the reader was encouraged to mock her talkativeness, but in the third novel we are lead to admire her ability to scheme and manipulate through her speech. This ability serves her well; her clever talk turns a profit with the Americans in New Orleans and Philadelphia and also helps Major Allen escape from sticky situations.

The Widow's overwhelming vanity leads to an appearance which is even more grotesque than her talkativeness. She prides herself on being a beauty from her youth through her middle age. When she is expecting a child in The Widow Married, she wants to have a girl exactly like herself because she thinks she is as handsome at thirty-nine as she was in her youth; she believes it is more desirable to have a girl when there is great family beauty (Ch. I). When the Widow is fifty-five, Patty describes her mother as the "the vainest old soul that ever walked the earth" (BA, 
Ch. XXXVIII). Her outlandish appearance arises from her vanity and her constant desire to appear more youthful than her chronological age. To this end, she appears rouged, ringleted, feathered and colorfully dressed in overly decorated clothing. Unfortunately, her cosmetic and sartorial improvements are so excessive that they are as coarse and vulgar as her personality.

The Widow's cosmetics-her rouged cheeks and false black ringlets--are among the most prominent and grotesque aspects of her appearance. In The Widow Barnaby, her Peters' cousins find her features handsome and her eyes fine. These positive qualities, however, are "exaggerated into great coarseness by the quantity of rouge she wore and the redundance of harsh-looking, coal-black ringlets which descended heavily down each side of her large face...so as to give a striking resemblance...to the wax heads in a hair-dresser's" shop (WB, vol. 1, Ch. XVIII). Rachel Williams, a Quaker woman in The Barnabys in America, criticizes the Widow, as a woman of such "ripened age, for wearing ringlets and lovelocks fluttering with every breeze that blows" (Ch. XXXI). It is apparent the ringlets are false as they disappear when her daughter Patty is born and reappear as she recovers from childbirth--“a copious quantity of ringlets appear gradually until they spread [their] lurid glories on each side of her radiant face" (WM, Ch. II). Similarly, the application of a little rouge increases day by day until by the end of the month "appeared as a glowing representation of youth, beauty and health" (WM, Ch. II). As coarse as her coal-black ringlets may be, her heavy-handed application of rouge is far more objectionable to the other characters in the trilogy. 
The frequent references and near-unanimous disapproval voiced by the other characters in the trilogy mark the Widow's rouge as both vulgar and even transgressive. Her brother-in-law, Mr. Peters, at first approving of the Widow's attractiveness and charm, is totally disillusioned when his wife informs him the Widow owes her colorful cheeks, not to good health, but to rouge. Although at first welcoming to her, he decides that he will "feel more comfortable when the rouge pots were all gone" from his house lest they become a bad influence on his daughters (WB, Ch. XVII). Mrs. Peters so disapproves that she insists on transporting the Widow in a close carriage out of fears she will be "brought down if identified with the widow and her rouge in public" (Ch. XVI). From their first meeting until the end of her visit, the Peters family refers to her rouge every time they mention her. Other characters besides the Peters notice and disapprove of her tendency to paint. Col. Hubert, for example, hesitates to court Agnes because he views the Widow and her cosmetics as vulgar and repulsive. Lord Mucklebury mocks her for her overapplication of paint. The Rev. O'Donagough instructs her to stop rouging until his missionary appointment to Australia is secure because he fears the committee will conclude, because of her cosmetics use, that they are not appropriate candidates. On this occasion, she tones down her makeup, "paling the tint of her glowing rouge, and straight[ens] her ringlets" until she is approved by the missionary society (Vol. 3, Ch. XIV). This is one of the few occasions she lightens her makeup, as she normally ignores or flouts the censure of the other characters. 
The other characters' unanimous disapproval of her rouge reflect the stigma attached to cosmetic paint during the early years of the Victorian period ${ }^{37}$. In his historical examination of cosmetic use in England, Neville Williams describes the shift from a free use of rouge in the eighteenth century to its censure in the beginning of nineteenth century. As a result, a heavy application of makeup was seen as immodest and a sign of bad breeding. The Widow, on the contrary, applies her rouge copiously and obviously with little attention to its lack of respectability. Her bright red cheeks mark her as vulgar and a women of bad breeding. Just as her slim and abstentious niece provides a sharp contrast with the Widow's corpulence and appetite, her niece Agnes' pale, unrouged face serves a sharp contrast with the Widow's rouged cheeks. The narrator continuously highlights Agnes' upper-class habits and preferences, ostensibly inherited from her aristocratic father, comparing them with the Widow's lower-class vulgarity.

Cosmetic use in the early Victorian era was linked not only with bad breeding but with deception. Rouging was considered improper not only because it was a sign of vanity, but also because it was "a visual lie" (Heath 2002 97). The reader first hears of the Widow applying rouge when she is married to Mr. Barnaby, her first husband. The Widow begins wearing rouge in her early thirties, middle-aged by Victorian standards, in order to appear younger, to "cover her faded cheeks" (Vol. 1, Ch. VI). Her rouging continues through her mid-fifties as, in The Barnabys in America, she employs it to take ten years off her age (Ch. VI). Rouging to recreate youth, as the

\footnotetext{
${ }^{37}$ The Widow Barnaby trilogy was written and published from 1839-1844, the early years of the Victorian era.
} 
Widow does, was considered a "violation of the laws of nature, in bad taste, and breach of sincerity" (Heath 2002 97). Similarly, Elizabeth Carolyn Miller points to the incompatibility of makeup and its connotations of "artificiality and duplicity" with traditional Victorian values of feminine "artlessness and naturalness" (322). The duplicitous aspects of the Widow's makeup are emphasized when she washes it off to appear sick as part of her plan to escape first the Beauchamp plantation and then, later, a suspicious lawyer on the steamboat. The effect of its removal is so startling that first the Beauchamp slaves, and then later her fellow steamboat passengers, have no doubt she is seriously ill and conclude she must receive immediate medical attention. Both the presence and the subsequent removal of rouge are employed for deceptive purposes; the rouge disguises the faded cheeks of middle age while its removal supports her false illness. The result of which affords the Barnabys' escape from the consequences of their criminal activity. The Widow, of course, is no stranger to deception as she lies constantly about her age and her financial and social status; she also deceives, more subtly, through her application of and removal of rouge.

Rouging became increasingly popular over the course of the nineteenth century and eventually became linked with the freedoms of the late-nineteenth century New Woman. From the 1860s onward, women of all ages and classes began to use cosmetics more frequently and more openly. ${ }^{38}$ Neville Williams argues that painted faces were one of the visible and striking signs of women's emancipation in the

\footnotetext{
38 In response, Eliza Lynn Linton in her 1868 essay "The Girl of the Period" wrote disapproving of, "the girl of the period [as] a creature who dyes her hair and paints her face, as the first articles of her personal religion" (413). Linton continues her article by advocating for a return to a time when English girls were content to be what God and nature had made them.
} 
1890's (110). Similarly, Miller argues that makeup use rose in correlation with women's social and sexual freedom so that its application denoted a pronouncement of the "self as a sexual being" (323). This attitude was a departure from the midnineteenth century "performance of sexual disinterest that had been compulsory" for Victorian women (323). In the trilogy, especially in the first novel, the Widow's use of makeup as a sign of her youth, sexuality and availability on the marriage market are predictive of late-nineteenth-century mores and women's emancipation.

The Widow's cosmetics, like her bright clothing, highlight her independence and transgressiveness. In her analysis of Lady Audley's Secret, Rebecca Kling argues for the subversive potential of makeup as a "manipulation of outward appearance" and as a means of advancement (576). Kling views cosmetics as an "indispensable tool" as women utilized whatever they could to make their mark and develop agency in the public sphere (576). Kling's discussion, of course, references sensation novels, a genre which appeared twenty years after Trollope's 1839 The Widow Barnaby. Despite its earlier appearance, the Widow, like Lady Audley, employs cosmetics as a "manipulation of outward appearance" and as a means of her advancement in an advantageous marriage. Her makeup is a sign of her agency as she launches herself in the world with the benefits of social and financial freedom.

The Widow's grotesque and vulgar appearance is intensified by her ostentatious dress. One of the Widow's chief pleasures during her marriage to Mr. Barnaby is spending money on excessively fine clothes and accessories. She revels in the "splendor of her elaborate toilet" which she changes at least four times per day (WB, 
Vol. III, CH. II). The Widow aims for the elegant appearance of a fine lady, but instead her expensive splendor, consisting of satin, feathers, flowers, and a profusion of the finest lace, appears overly ostentatious and vulgar. In addition, she makes herself more conspicuous by the very bright colors she assumes, despite the recent death of her first husband. On one occasion, she wears a "bonnet of bright lavender satin" while her black silk dress is trimmed with "as many settings off of the same color with her bonnet as it was possible to contrive" (Vol 1., Ch. 18). Her grotesque, over-thetop attire is frequently noted by the narrator and other characters. Colonel Hubert, for example, refers to her as "that feather and furbelow lady" (WB, Vol. 2, Ch. II). Trollope highlights the Widow's showiness through a contrast with Agnes' simple and understated elegance. When the two women attend church, Agnes appears in simple mourning dress while her aunt wears a "gay bonnet ...decorated with poppy blossoms" and a colorful "profusion of her own embroidery on cuffs, collar and pocket-handkerchief" (Vol. 2, Ch. I). The narrator notes that they are "as strangely matched a pair in appearance as can well be imagined" (Vol. 2, Ch. I). This comedic juxtaposition continues in The Widow Married at the court presentation when the Widow and her daughter attend on the same day Agnes Hubert presents her daughter Elizabeth. The Widow and Patty's court dresses "contrived to accommodate more embroidery, more flowers, more fringe, more tassels and more lace than any two dresses ever carried before into a royal presence" (Ch. XXX). In contrast, Elizabeth Hubert's dress and her train are of white satin with a "corsage decorated only with pearls" (Ch. XXXI). When the women stand together awaiting their 
carriages, "everyone smiles and marks the whimsical contrarieties" (Ch. XXXI). The Widow's and her daughter's attire once again stands out as overly ostentatious and as an object of ridicule. Just as the novel underscores the contrast between their appetites and complexions, it also juxtaposes Agnes' upper class taste in clothing with the Widow's vulgar flamboyance.

One of the most noticeable aspects of the Widow's attire is how she covers her dresses with a "profusion of elaborate satin stitch" (WM, Ch. II). The Widow is quite skilled at satin stitch, an intricate flat stitch used to cover a section of background fabric, and she embellishes her dresses with an excess of this embroidery. Lambert links her disproportionate use of satin stitch with how the Widow "embroiders the truth to suit her own ends" (25). The Widow, Lambert claims, covers up the things she wishes to hide from society, her lower social and financial status, "by obscuring these under layers of visually distracting decoration" (25). Ironically, the profusion of decorations mark her as vulgar in the eyes of the very upper class characters she attempts to impress.

Unquestionably the Widow uses her attire to deceive. In The Widow Barnaby, her embellishments of brightly-colored trim on her dresses belie her recently widowed status and suggest she has already passed the requisite two years of, sociallyisolated, mourning. Late in the novel she again avoids widows weeds after her second husband's death by lying to her Sydney friends, telling them, "it was not the fashion in the old world for ladies of distinction to wear that dismal colour [black] for more than a month for any husband who died by accident" (WB Vol. 3, Ch. XVIII). In 
The Widow Married, preparing for a reunion with Lord Mucklebury after eighteen years, the fifty-five year old Widow desires to look as young and beautiful and slim as she did at their first meeting. Therefore, she concocts a "sort of floating maze of drapery" designed so "the eye cannot justly determine where the natural material ends and that of the dress begins - a sort of vapory, misty decoration [falls] around the shoulders from among which the still-handsome face should appear" ((Ch. XXVII). The dress is designed to conceal her increasingly corpulent figure as she attempts to deceive Lord Mucklebury into thinking she is as attractive and relatively slim as she was when in her thirties. The reality behind these draperies is her now majestically vast figure. Just as she plays the role of the wealthy, socially-appropriate widow, here she performs the role of a still-young beauty.

In the Philadelphia section of The Barnabys in America, we see the Widow continuing to adapt her costume to feign a new persona for deceptive purposes. She aligns her style with that of the Quakers' in order to further her schemes, so she simplifies her dress, hair and cap by stripping away numerous bows, pieces of lace and fake roses. In this case, she wishes to convince the Quakers that she shares their values so she can ultimately sell herself as an anti-slavery author. Similarly, while visiting the Beauchamp family in New Orleans, she displays her extensive and rich wardrobe to Mrs. Beauchamp, the plantation owner's wife, as a substitute for a letter of introduction to upper-class society. Ironically, her not-yet-paid-for dresses, which are also seen as vulgar in England, lend credence to her claims of membership in upper-class, English society. As part of her attempt to swindle them, the entry 
afforded by her rich dresses into the plantation owners' circles allows her to adopt the persona of the successful author.

As I discussed in Chapter 1, a typical Bakhtinian grotesque revolves around the excessive material body which consists of an obese, frequently female, body. The Widow Barnaby trilogy makes it clear through frequent descriptions of her size that the Widow's large body represents the excessiveness characteristic of the grotesque. Her weight, in fact, receives even more attention than her rouged cheeks and ostentatious dress. In The Widow Barnaby, Lord Mucklebury bluntly calls her a "darling creature, a widow, fair, fat, and forty...most fat!" (Vol. 2, Ch XIV). Similarly, Mrs. Peters describes her as a "tall, massive lady" as well as "large, ungainly and vulgar" (Vol. 1, Ch. XVIII). The Widow, on the other hand, vainly and unrealistically thinks of herself "as if she were still one of the lightest and loveliest nymphs in the world" (Vol. 1, Ch. XVIII). Her weight seems all the more excessive because of the constant contrast of her slim niece Agnes who can wear her aunt's hand-me-downs only after extensive alterations in size. In fact, Agnes performs the pale, delicate lady, an ideal female character as represented in nineteenth-century novels. As Michie demonstrates, thinness and an "interesting pallor," rather than rouged cheeks, became the defining characteristic of the early Victorian heroine as well as the lady of the period (Michie 1987 23). Agnes' presence continuously reminds us that the Widow, although the heroine of this trilogy, is very much not an ideal either as an early Victorian heroine or as the lady of the period. Instead, the Widow is a transgressive as well as grotesque character throughout the trilogy. 
As I described in Chapter Two, upper- and middle-class ladies were discouraged from eating heartily and, in fact, novels rarely pictured them enjoying food. The Widow, on the other hand, is often depicted enjoying her meals, especially desserts, and she speaks enthusiastically about her food. In The Widow Barnaby, the narrator tells us her "love for cakes and tarts was unextinguishable" (Vol. 2, Ch. 1). Similarly, when she is in debtor's prison, she demands Agnes visit her bringing along "lots of cake and brandy cherries" (Vol. 3, Ch. V). The Widow also demonstrates her selfishness by offering Agnes biscuits while she eats cake. Agnes again serves as a reverse foil because of her general disinterest in sweets and the ladylike way she picks at her food. In contrast, the Widow talks about learning to like nice eating as she eats all the cheesecakes at the bakery shop (Vol. 2, Ch. I). She seems to feel no compunction about her appetite nor any desire to hide it.

The Widow's corpulence, and thus her grotesqueness, increases as the trilogy continues. In The Widow Married, the Widow has spent fifteen years in Australia and in that time her person has greatly enlarged. Further, she "swells up even larger when she is angry" (Ch. VI). This novel constantly refers to her size as the narrator describes her "majestic vastness" (Ch. XVII) and compares her to a "huge elephant" (Ch. XXXI); Patty tells her mother she is an "enormous size" (Ch. XXXI); Mrs. Stephenson is struck by her "august expansiveness" (Ch. XVII); and Agnes notes how she "spread out into such startling immensity" (Ch. XXIX). Trollope also encourages the reader to mock the Widow by putting her in physically challenging situations. For example, she is so large she has troubling entering the stagecoach and needs the 
combined assistance of the coachman as well as her husband who must push and pull her to get in.

In The Barnabys in America, Trollope does not emphasize the Widow's weight as extensively, but she is clearly still very large. In Philadelphia, for example, the Widow's size is made clear when the narrator describes her clothing as "floating drapery usually worn upon her ample shoulders" (Ch. XXX). Despite her size, the Widow at fifty looks ten years younger and has retained a great deal of her "personal beauty" (Ch. VI). In this novel, as in the previous two, her corpulence and "majesty" draw other characters' attention and their reactions alternate between awe and derisive laughter. This paradoxical quality of the grotesque, a mix of contradictory emotions, produces discomfort in the reader or viewer so their impulse to laugh is mixed with repulsion. As I discuss in more detail below, contemporary reviewers felt a similar paradoxical reaction to this character. The fact that the Widow produces this reaction underlines the grotesqueness of her character.

In The Barnabys in America the narrator comments, the Widow "could always find, or make opportunities to display both her mind and body to advantage" and that while on board ship "she clearly made them all understand she had some few years ago been infinitely handsomer still" (Ch. VI). While her "majestic" size draws attention, the Widow's overall appearance and behavior also attract notice. Her height is also quite extreme which adds to her massiveness. Several characters 
throughout the trilogy remark on her stature ${ }^{39}$. Her sister-in-law refers to her as a "plumed giantess" (WB, Vol. 1, Ch 16) Her excessively showy dress, her furbelows and feathers, are designed to make her stand out. Further, her heavy-handedness with the rouge pot makes it quite apparent that her rosy cheeks are not the result of health or blushing modesty - she is clearly wearing makeup. In addition, her vivacity with her constant talk and loud laugh ringing out during public appearances draws amusement and disapproval. She certainly does not strive for a ladylike modesty or reserve as represented by her niece. Instead, the Widow enjoys drawing attention to herself and thus transgresses norms for the ideal middle-class woman as well as the typical heroine of a mid-nineteenth century novel. In short, she makes a spectacle of herself.

As I described in Chapter One, Mary Russo theorizes that the history of literary and artistic representation, as well as the history of public and political discourses, reflects and reinforces the imperative that women keep themselves small and unseen, that they neither take up too much space in the world, nor make spectacles of themselves. She describes a spectacle as a woman who transgresses norms through their appearance and/or their behavior. The Widow, as we have seen, transgresses norms through her corpulent body, overly decorative attire and headwear, thickly applied makeup, and loud talk and laughter. The Widow continuously makes a spectacle of herself. Her transgression of norms, however,

\footnotetext{
${ }^{39}$ In her discussion of the Widow's height, Carolyn Lambert suggests that because she is tall has large hands and displays masculine behavior, her gendering is unstable. Lambert labels her appearance "quasi-hermaphrodite" and argues she is not only original but that her tallness suggests mannishness (Lambert 2018 24).
} 
assists her in her picaresque career rather than leads to her downfall. Her grotesqueness affords her the opportunity to invert gender and class hierarchies and thus challenge socio-cultural norms.

The Widow consistently attempts to invert her middle-class status as she strives for greater wealth and acceptance into upper class circles. From the beginning of The Widow Barnaby, she endeavors to produce an appearance of wealth and class despite her birth family's relative poverty. As a widow, she attempts to pass as a lady of great fashion. Although Mr. Barnaby left her a comfortable income, she represents herself as more well-off to everyone she meets during her travels in Clifton, Cheltenham and London. She takes special care with her appearance in the belief that both her ostentatious dress and makeup add to her beauty and mark her as wealthy. Ironically, the Widow's appearance, including her corpulence, makeup and dress, as well as her behavior, her talkativeness and loud laughter, designate her as lower class and vulgar. She is so objectionable to the upper-class Colonel Hubert, Agnes' future husband, that he is initially hesitant to court Agnes because of her association with "such a dame as that feather and furbelow lady" (WB, Vol. 1, Ch. XVII).

Her class status, however, undergoes alterations in the second and third novels in the trilogy, leading eventually to a Bakhtinian inversion of class status suggestive of a carnivalesque atmosphere. In The Widow Married, she and Major Allen acquire aristocratic friends who visit their house frequently. Although these guests are chiefly card players interested in Major Allen's high-stakes games, they do call on the 
Widow, acknowledging her as a friend despite her vulgarity. In addition, during this period they move into a mansion and entertain in high style, partly to persuade aristocrats to attend and partly because the Major has made a great deal of money from cheating at cards. Their money and new acquaintances also afford them the opportunity to present Patty at court which is one of their chief ambitions. This change in status also leads to a change in the Widow's behavior. In the first half of the novel, the Widow greets her English relatives effusively by hugging, kissing and crying over them. In the second half, however, she becomes more dignified; she is no longer as emotional around them and speaks more softly. Interestingly, although the Hubert and Stephenson families do not particularly welcome the relationship, it affords respect for the Widow among her friends and acquaintances. Her new friends, the Perkins sisters, for example, admire the Barnabys and think of them as upper class because they observe the Huberts calling on them. Similarly, Frederik Egerton, in The Barnabys in America, is also impressed by their relationship with the Huberts; he therefore assumes the couple must be more refined than they appear. In the third book the Widow once again represents herself as upper class, but in America, unlike England, she is able to mislead others by bragging about her aristocratic friends and appearances at court. Humorously, her expensive clothes, which she has never paid for, serve as proof of her status. All she has to do is display her extensive wardrobe to Mrs. Beauchamp and the plantation owners accept the Barnabys as upper class. Trollope pokes fun at how Americans, who claim to be disdainful of English royalty and aristocracy, are actually terribly impressed by it. The 
Widow plays on this hypocrisy to achieve acceptance and admiration. In the third book of the trilogy, therefore, her class status is temporarily inverted from her earlier, lower status, position. In America, she is part of the upper classes, a status she could never fully achieve in England.

Through her eponymous and transgressive character, Frances Trollope produces a satirical view of romantic marriage and female domesticity. Christine Sutphin refers to the Widow Barnaby as a "subversive element" within the gender hierarchy who turns the "ideology of true womanhood to her advantage" (227). Her first marriage and subsequent widowhood challenge the notion of a marriage based on affection. The Widow regards her marriage to Mr. Barnaby, a wealthy apothecary, as a compromise, because of her failure to land a wealthier, higher-class husband by her early thirties. Ironically, Mr. Barnaby's death, after only a few, short years of a lessthan-romantic marriage, marks the beginning of his widow's possibilities for adventure. Although she weeps with "little or no effort" several times during the week he dies, she quickly recovers from her grief when she learns the terms of her husband's will (Vol 1, Ch. X). He leaves her "sole executrix and sole legatee of all he possessed" and she is overcome by feelings of pride and happiness (Vol 1, Ch. X). She revels in her newfound "independence and her wealth" and the fact that "no human being existed who had any right whatever to control her" (Vol 1, Ch. X). The Widow views herself as a free agent from the beginning of her widowhood, an attitude antithetical to nineteenth-century cultural norms of female submissiveness and dependence. She is an unconventional widow indeed, for her thoughts soon turn to 
remarriage and entering society, rather than avoiding it as a conventional widow should. While a traditional widowhood was seen in the nineteenth century as "an involuntary commitment to a form of social exile," the Widow refuses to wear mourning attire and she quickly re-enters society (Jalland 231). Her pursuit of a new husband is based on a desire for greater wealth and status rather than on a submissive woman's need for love and support. Even when she succeeds in remarrying, she protects her money and remains independent through her insistence on keeping her income for herself. In fact, the Widow's marital adventures throughout the trilogy challenge the ideal of domestic ideology.

Her plans to remarry for increased wealth and status mock the contemporary ideal of romantic marriage. As Helen Heineman argues, in the Widow's worldview, husbands are not for romance, but "necessary evils for financial security and good society" (90). The Widow logically balances her ambition, a rich and fashionable husband, with her assets--beauty, fortune and talents. Her one deficit, she decides, is access to good society where she might meet a man of greater fortune than she can find in Silverton. She decides to visit her wealthy sister-in-law, Mrs. Peters, in Clifton in order to meet "people above herself" (Vol. 1, Ch. X). In Clifton society, she plans to take advantage of all her opportunities, to "turn all accidents to account" and to employ each new acquaintance in meeting another (Vol 1, Ch. X). The Widow never hesitates to employ others to promote her machinations. The Widow's rather calculating response to widowhood and remarriage transgresses the conventions of female dependence and a widow's overwhelming sorrow. Instead of relying on her 
relatives for advice and support, she intends to use them for her advancement.

Rather than living in a widow's social exile, she schemes to broaden her social life.

Rather than spend the traditional two years mourning Mr. Barnaby, she is ready to remarry after only three months which is, in light of nineteenth-century mourning rituals, a transgressive attitude.

A nineteenth-century widow was required to adhere to a stringent dress code for the first two years after her husband's death ${ }^{40}$. The mourning period was aligned with social isolation, since a widow was not supposed to accept formal invitations or appear in public places for the first year. The Widow flouts this convention by finding her mourning weeds "so hatefully unbecoming...that she firmly believed the inventory of it must have been actuated by some feeling akin to that which instituted the horrible Hindoo rite of which she had heard, whereby living wives were sacrificed to their departed husbands" (Vol. 1, Ch. XIV). Here she suggests that women's identities should not be subsumed by those of their husbands'. Her subsequent behavior confirms this view. Only three months after her husband's death, while visiting Exeter, she appears first in lavender half mourning and then includes every "color of the rainbow...amidst her trimmings and decorations" (Vol. 1, Ch. XIV). She

\footnotetext{
${ }^{40}$ According to Pat Jalland, a widow wore non-reflective black materials, paramatta and crape, for the first year of deepest mourning. In the next nine months, a widow donned dullish black silk, heavily trimmed with crape and, in the last three months, the crape trim was discarded. She was allowed to change into the "colors of half-mourning, such as grey and lavender or black and white," for the final six months (Jalland 300). Further, the drab, uncomfortable attire "symbolized the perception" that a wife's identity and sexuality were "subsumed in her husband" and thus died with him (301). Widows weeds signified a woman's absence from the marriage market, a reflection of the contemporary prejudice against widows remarrying (Heath 2006 31). Mourning-dress in the Victorian period fulfilled multiple purposes including identifying the mourner, showing respect for the dead, eliciting the sympathy of the community and matching the mourner's somber mood (Jalland 301).
} 
tells Agnes that deep mourning attire makes her poor heart ache even more, so she cannot bear to wear them. Of course, she conveniently ignores the fact that, according to mourning customs, her heart should ache for two years. Her transgressive flouting of customs contrasts with Agnes' more conventional appearance in mourning clothes. Agnes continues in black partly out of respect for her uncle and partly at her aunt's request. Although the Widow claims Agnes looks well in black, the narrator reports that she actually requires this because it will save her money to have her black dresses made over for her niece. Later, she lies to her in-laws, the Peters family, claiming that Agnes herself chooses to wear black because of her depression. In Cheltenham, she lies again, pointing to her supposed duty to Agnes as an excuse for the early resumption of her social life. This convenient lie allows her to circulate in public at the Pump Room and library every day despite her widowed status.

In furtherance of her schemes, as well as an additional example of her transgressiveness, the Widow lies about both her age and the length of her widowhood. By describing her sister Sophia, Agnes' mother, as the much older sibling, she, ludicrously, implies that she is a close contemporary of sixteen-year-old Agnes. In reality, Sophia was her younger sister. Amusing as her falsehoods may be, they actually fulfill a deeper purpose by increasing her chances at achieving a wealthy husband. Her rouging is another form of deception as she uses it "to cover her faded cheeks" another example of her effort to appear younger and more beautiful (Vol. 1, Ch. 6). As Kay Heath argues, she "accelerates the chronology of her widowhood" 
because she is running out of time to remarry (2002 90). In her mid-thirties during the first novel, the Widow would be considered middle-aged by Victorian standards. Further, according to the 1851 census, the marriage rates of widows between the ages of 35 to 39 was $7.3 \%$; this rate dropped to $4 \%$ by the age of forty (Jalland 254). With every year that passes, therefore, the Widow has a reduced chance of marriage. She cannot afford to wait through two years of social isolation. Despite her vanity and love of bright colors, she is clearly aware how disrespectful her attire would be viewed, so she lies again and again.

Her reaction to Mr. Barnaby's death is an additional example of her grotesqueness. Her behavior produces both amusement and repugnance in the reader, the paradoxical response characteristic of the grotesque. Beyond a short week of intermittent weeping, she appears not to suffer from Mr. Barnaby's death. In fact, only a short three months later, she feels happy to be "a rich and handsome widow travelling to Exeter" (Vol. 1, Ch. XIII). Her optimistic attitude challenges the conventional idea of marital happiness characterized by a wife's enduring love for and dependence on her husband. Trollope's mockery of marriage forces the reader to question how many women marry for practical reasons and, thus, how many wives truly love their husbands. The Widow's happiness and independence in widowhood are reflected in her brightly-colored, decorative clothing. Her clothing, therefore, signifies a cavalier attitude toward her first marriage and a manipulative strategy for acquiring a new, improved husband. 
Trollope also satirizes the Victorian novel's romantic marriage plot through the Widow's humorous attitudes toward and strategies for husband hunting. Her behavior suggests the possibility of a different, and unconventional, social norm in which women openly pursue financial gain. As in Bakhtin's theory of carnival, a comic grotesque character can reveal how the supposed naturalness of the social order is in fact artificial by unveiling the truth. In The Widow Married, we learn one of her strategies when the Widow advises fifteen-year-old Patty on finding a good husband. Her advice is not based upon Patty's attracting a man based on her modest behavior or her beauty but rather on her own wealth. The Widow declares, "a girl's chance of a good match is doubled and trebled a hundred thousand times over by her having some money herself" (WM, Ch. XII). Through this statement and her own behavior, the Widow clearly equates a good marriage with a business transaction where the bride's money assists her in catching a wealthy husband. In the first novel, the Widow employed this strategy in her romance with Lord Mucklebury by spending a lot of money to keep a high profile and appear rich. In love, not with Lord Mucklebury himself, but with the idea of becoming a Viscountess, she equips herself with additional servants and more luxurious clothing and accessories to impress him. Unfortunately, her investment is a poor one as Lord Mucklebury courts her only for his own amusement and has no intention of marrying her. For the first and only time in the trilogy, the Widow is not fiscally prudent, as her investment yields no profit. While we sympathize with her disappointment and humiliation, at the same time we realize that her ambition, rather than her heart, attracted her to Lord Mucklebury. 
During her husband-hunting adventures, the Widow may pretend to be a helpless widow, but she never loses sight of her goal to improve her financial and social status through marriage. Throughout her flirtation and engagement to Major Allen in The Widow Barnaby, she is enamored with him, but love is "second in her heart to a passion for wealth and finery" (Vol 2, Ch. VI). Her first priority is to make a good bargain when she remarries. Therefore, she is determined to "be very sure of the Major's rent-roll" before she bestows herself and her fortune upon him (Vol 2, Ch. VI). She has already thought through the settlements and decided she will give her fortune to him in exchange for 1,000 pounds per year. Of course, the Major does not have anywhere close to 1,000 yearly; instead, he lies to her about his supposed fortune just as she has exaggerated her own estate. When she finds out he is lying about his fortune, she immediately breaks their engagement.

Similarly, at the end of the novel, she meets the young and handsome Mr. Patrick O'Donagough, the natural son of a lord. When he proposes, she suggests a month's probation during which they can both "inform themselves first of the worldly condition of the other" (Vol. 3, Ch. XI). The Widow, wanting to know the real state of his affairs, "pursues inquiries" with the man who got him a job as a domestic chaplain (Vol. 3, CH. XIV). Even though she is satisfied with his recommendation, she is still determined to maintain control of her money so insists her income is settled on her after her marriage. Marriage to Mr. O'Donagough is a compromise. While he is not the wealthy match she originally dreamed of, she calculates the Reverend O'Donagough will look very well in the Exeter paper and he is handsome and a 
decade her junior (Vol 3, Ch. IX). The Widow will at the very least not suffer

financially from their union. As with Major Allen, Mr. O'Donagough's attractiveness is an important consideration, but the state of his finances predominates over her feelings.

After O'Donagough's death, she meets Major Allen again, only a year or two after they met in Clifton. Her affection overpowers all her doubts so she marries him. Although her affection may be overpowering, she still makes sure "all she had should be firmly settled upon herself" (WB, Vol. 3, Ch. XVIII). During the first few months of their marriage, Major Allen tries to wrest control of her finances away from her but she stands firm. She continues to manage her money and her money supports them during their fifteen years together in Australia. Although she pretends a ladylike delicacy around practical matters, in reality she is controlling and businesslike in her marriage.

Trollope further highlights the Widow's more cynical approach to courtship, as well as the unorthodox nature of her marriage to Major Allen, through the presence of a traditional romantic marriage subplot in each novel of the trilogy. While Agnes Willoughby, Elizabeth Hubert, and Annie Beauchamp enter traditional marital relationships based on mutual affection, the Widow bases her decisions on financial gain putting affection second. Although her eventual marriage to Major Allen is based on affection, their marriage is far from the ideal of domestic ideology. Instead, their relationship develops and deepens as a result of their engagement in nefarious schemes, first separately and then together. As they become more aware of each 
other's skills and assist each other in their plans, they learn to respect one another's cleverness. In addition, as I already discussed, the balance of power in their marriage continuously shifts until, at the end of the trilogy, the Major acknowledges the Widow as the superior partner in their marriage, placing her intelligence and inventiveness above his own.

The Widow is not only an unorthodox wife, she is a highly unusual heroine for a nineteenth-century novel. The reader realizes this early on in the first novel when the narrator reports that the Widow would "rather gain things through intrigue than straightforwardly" (WB, Vol 1, Ch. 6). Indeed, the Widow proves to be a liar and a cheat, engaging in multiple deceptions and nefarious schemes throughout the trilogy. As a young woman, for example, she pretends to a shop owner that she is engaged to a wealthy officer so that she might buy a ball dress on credit. In addition, she continuously attempts to charm her wealthy aunt, Betsy Compton, in order to wrangle money out of her for expensive clothing so she can appear wealthy to potential suitors. As she later tells her daughter, in The Widow Married, the "best way [for a young woman] to get a rich husband is by having money herself" and, if a woman is not wealthy, she needs to present the appearance of wealth through deception ( $\mathrm{CH} . \mathrm{XV})$. As a middle-aged woman, she continues to lie about her financial and social status. In The Widow Barnaby, while on the hunt for a second husband, she claims, for example, to be the widow of a gentleman of large fortune rather than the widow of an apothecary (Vol. 1, Ch. 14). She exaggerates her fortune and speaks of her non-existent sizeable estate, Silverton Park. 
Although the Widow succeeds in remarrying, she continues to lie about her wealth, age and social status during the second and third novels in the trilogy. She persists with dissembling in order to invert her middle-class status into a position in upper-class society. During The Widow Married, she claims a close association with the wealthy and respected Hubert and Stephenson families as part of her campaign to achieve a court presentation for herself and her daughter Patty. She also supports her husband's efforts to associate with wealthy young men so he can win their money by cheating at cards. In The Barnabys in America, she once again lies about her membership in upper-class society and claims that she visits court frequently as a means of impressing the wealthy plantation owners with her own importance. In one amusing scene, because she has no letters of introduction, she gains status with a plantation owner's wife by displaying her expensive clothing and accessories. Because the Widow left London without ever paying for these dresses, there is a delicious irony in her using them as a passport for respectability.

In the third novel, her lying blossoms into outright fraudulent money-making schemes as she masquerades as a famous English author in order to swindle money from her victims. In New Orleans the Widow begins writing a book praising American with a special focus on supporting the slave economy. After her reading of the first chapter, she wins accolades from the wealthy plantation owners who compete over inviting her and the Major to house parties. She calculates that they can save on living expenses for several months by taking advantage of this hospitality. Ironically, before they can reap the full benefits of these invitations, they must flee New 
Orleans because the Major wins too much money cheating at cards. Though disappointed, the Widow quickly turns to new schemes. In Philadelphia, she again claims to be a successful author interested in writing a book praising America. This time, to suit her audience of Quaker families, she proposes a book criticizing the evils of slavery. She manages to swindle a $\$ 500$ subscription out of the Quakers before the Barnaby family is once again on the move.

The Widow is an unorthodox heroine, not only for her deceptive adventures, but also for her businesslike attitude, similar to that of Lady Olivia in Pin Money. In this way, she subverts gender roles by taking on more traditionally masculine qualities. For example, upon Mr. Barnaby's death, she negotiates the sale of his house and his business for about "half again as much as it was worth" plus three months continued residence, which proves, the narrator reports, "she doesn't need an executor" as she has a good head for business (WB, Vol 1, Ch. 10). Similarly, she bases her search for a second husband on her desire for wealth and social status rather than a desire for emotional support, love and/or an alleviation of loneliness. After his death, she decides that her income, 400 pounds per year, is not enough for her plans of "selfaggrandizement," so she pursues a rich and fashionable second husband (Vol. 1, Ch. 10). She reasons logically by balancing her ambition: "a rich and fashionable husband" against her assets: "beauty, fortune and talents" and her deficits: the need to procure "free entrance into good society" to achieve her goals (Vol. 1, Ch. 10).

Despite her logical planning skills, the Widow's path is not always smooth. Her initial plans to marry the Major fall through when she discovers he has lied about his 
financial status. She also fails with her second potential husband, Lord Mucklebury, because he was never serious about their romance. Her pursuit of Lord Mucklebury leads her to her only poor business decision. She sells some of her principle in order to present a façade of great wealth. When their relationship ends, she not only ends up without a husband but her income is also significantly reduced. Despite these setbacks, the Widow always perseveres and continues to advance through her cleverness. Although the Widow's grotesque appearance and excessive talk makes her a figure of ridicule, she is also powerful because of her manipulative talents. As I discuss below, she achieves an unusual status in her marriage through her inversion of gender roles.

The Widow's vulgarity in appearance and behavior, along with her unscrupulous scheming, deviate significantly from the feminine norms of the mid-nineteenth century, especially those represented in novels of the period. Literary critics (including Helen Heineman, Christine Sutphin, Carolyn Lambert, Kay Heath and Robert Barnard) have described the Widow as an adventurer, a rogue, a fascinating comic villain, and a highly original creation. Contemporary reviewers recognized and highlighted the originality of Trollope's character. For example, an unsigned reviewer in the Times stressed the uniqueness of the character stating, "The Barnaby is such a heroine as never before has figured in a romance. Her vulgarity is sublime...such a jovial, handsome, hideous, ogling, bustling monster of a woman as maid, wife, and widow was never, as we can recollect, before brought upon the scene" (24 January 1839). Her character as a deceptive, amusing, and traveling rogue who violates social 
norms mark her as a picara and the novels, correspondingly, as part of the picaresque genre $^{41}$.

Helen Heineman credits Frances Trollope with creating the "feminine picaresque," one who schemes to exploit life's possibilities for a middle-aged woman (1979 157). Heineman points out that with the exception of Moll Flanders, a lower class version of the picara, the few women picaresques in literature were usually minor characters (1979 157). The Widow, on the other hand, is a middle-aged and middle-class female picaresque who is the main protagonist of not just one novel, but of a trilogy of novels. In the Widow Barnaby character, Trollope combines dishonesty and deception with comedy and likability. Although she could have continued in Silverton and lived a comfortable and respectable life, the Widow's ambition leads her, in typical picaresque fashion, to leave home in search of her aggrandizement. The Widow's age, vulgarity and open ambition represent a distinct divergence from the stereotypical heroine of the mid-nineteenth century.

Although Trollope creates a picaresque heroine, she departs from the genre's traditions in that her heroine never repents nor is ultimately punished for her schemes. In fact, despite several setbacks, she perseveres with her schemes and she ultimately succeeds in many of her goals. For example, after she spends a great deal of money to prove her eligibility to be a Viscountess, her romance with Lord Mucklebury fails to end in marriage. At first angry and seeking revenge, she soon settles for friendship with him. Furthermore, at her lowest point, when she ends up

\footnotetext{
${ }^{41}$ See Barbara Babcock's definition of the picaresque as a type of satirical novel whose hero is an amusing vagabond who tells of his life and adventures in a loose, episodic fashion.
} 
in debtors' prison for neglecting to pay her bills, she befriends a fellow inmate, the handsome Rev. O'Donagough, and eventually marries him to start a new life in Australia. Although she suffers a brief punishment for her fiscal irresponsibility, she is ultimately rewarded by her time in prison. Similarly, during her third marriage to Major Allen, she eventually profits, both emotionally and financially, from her schemes. Just as in the first novel, she suffers setbacks, especially when Major Allen's card cheating leads to the family banishment from New Orleans just as she succeeds in her persona as a famous author. Her setbacks, however, do not lead her to reform her ways or to indulge in recriminations. Instead, she quickly moves on to the next scheme, convincing the Quakers she is an anti-slavery author, and successfully swindles them out of $\$ 500$. Her career of deception, therefore, is not only transgressive toward traditional gender roles but even transgressive of picara traditions in which "social and poetic justice, as defined by the male establishment, guarantee[s] that [anti-heroines'] freedom is as short-lived as their success" (Sutphin 227). The Widow's successes are not short lived; the trilogy ends as she sets off on new adventures in France. Further, her freedom is not curtailed even, as I discuss below, by her marriage.

According to Barbara Babcock, a picaresque narrative "defines itself" through explicit inversions of accepted social norms and institutions (95). As a genre, the picaresque inverts and parodies the typical romance hero's quest pattern. The romance hero in a quest narrative travels and undergoes "a liminal experience" to find his sense of self and thus "realize symbolic power through victory in his tasks" 
(100). This attainment of power affords a change in his status that, in turn, leads to his re-entry into society from a marginal or liminal space. The picaresque narrative, however, substitutes a low life delinquent for a higher status hero. The picaresque character, declining to climb the social ladder through hard work, opts instead for the truly "marginal position" of being a half-outsider who can neither join nor reject his fellow men (104). Further, the picaro pursues the material, such as physical comforts and delights of the flesh, rather than the spiritual and, thus, appreciates immediate gratification. Similarly, the Widow, as we have seen, would rather gain things through intrigue than straightforwardly. As a liar and a cheat, she never truly joins a community of her fellow men or women, but looks upon them as her potential victims. Further, her appetite for food and expensive clothing highlights her desire for the "immediate gratification of material things" (Babcock 105). Although hungry to join upper-class society, her grotesqueness and vulgarity prevent her acceptance and thus, like a traditional picaro, she also exists on the margins of society, in a liminal state of being "betwixt and between" (Turner 1974:232). This liminal state affords the opportunity to transgress and destabilize boundaries of conventional society. One of the important results of the picaresque's inversion of social norms and institutions is the genre's ability to satirize them and speak the truth about society from an ironic perspective (Babcock 98). As I have discussed, the Widow Barnaby trilogy, as a set of picaresque novels, satirizes traditional marriage and inverts the traditional marriage plot through the Widow's business-like search for a wealthy husband. In addition, the effect of the inversions characteristic of the picaresque is to 
"render ambiguous categories which are usually distinguished such as good and evil" (Babcock 110). The categories of good and evil are constantly blurred in these novels. The Widow is a likable and amusing character as well as a selfish schemer who acts only for her own financial and social gain without bowing to cultural or even legal expectations. The reader is placed in the ambiguous predicament of rooting for her success while at the same time condemning her motivations and actions.

In The Widow Married and The Barnabys in America, the Widow Barnaby/Major Allen marriage consists of a power struggle in which they compete to gain the upper hand in financial matters and domestic arrangements. This marital power struggle leads to an inversion of traditional gender roles resulting in the Widow eventually assuming control of the family schemes and asserting her superior intelligence over her husband. In the opening of The Widow Married, the Widow appears to hold power over the Major because she manages their finances after she wins the marital battle for control over her income. At the beginning of their marriage Major Allen wants to "take her income under his own immediate and separate control; but here, after a somewhat spirited debate on occasion of the two first quarterly payments, he gave in, Mrs. Allen not being a woman to give way easily" (Ch. Il emphasis mine). Because of her stronger will, the Widow maintains control over her income just as she did in her second marriage to O'Donagough. Her independence and her complete control over her "tightly-settled and regulated income" are highly unconventional marital arrangements antithetical to the law of coverture and traditional gender roles (Ch. II). The power dynamic in their marriage, however, frequently shifts throughout 
the novels. Although she wins this battle, the Major retaliates by not sharing any of

his gambling winnings with her. Her money supports their household but she is not in control over or even fully cognizant of his income or his activities. Interestingly, although the Major is certainly aware of her past misdeeds - her lies about her imaginary fortune and her stay in Fleet prison-he never reproaches her. The Major certainly does not perform the role of an authoritative husband or hold her to a higher standard; there are no repercussions for her past misdeeds. ${ }^{42}$

The Widow thinks and behaves far more independently than the ideal, the nineteenth-century angel in the house. The Widow hopes to arrange an advantageous marriage for her daughter Patty, so she resolves to exploit Agnes Hubert's social standing for Patty's benefit. Initially, her plans do not necessarily include her husband. She is so independent that she is determined to go back to England even if she has to leave him behind. Fortunately, he too wishes to return and suggests they save his gambling money for Patty's launch into society. Although the Widow is glad they will return together and she will have his help with her plans, she

\footnotetext{
${ }^{42}$ Similarly, the narrator hints that the emotional aspect of their marriage is full of ambiguity and suspicion. Although they frequently display their fondness for one another, this façade conceals a mutual distrust. The tone of their endearments is quite singular so that, "a sharp observer might sometimes have fancied that there was some latent feeling of suspicion and reserve at their hearts" (Ch. III). Their distrust and reserve is quite natural considering how they both practiced deception upon the other when they first met in The Widow Barnaby. While the Widow exaggerated her fortune and claimed to own an estate back in Silverton, the Major claimed to be a rich war hero and confidant of Wellington. The Widow, however, discovered his association with a common thief and that gambling, rather than a private income, was his sole support. The narrator points out that the Major is not a confidential husband in that he never mentions his former felonious associates or "the manner of his voyage out," the real reason he left England for Australia (Ch. II). The Widow follows his lead by remaining silent about Silverton Park (her imaginary estate), her false claims of wealth and her stay in Fleet Prison. The narrator notes that the Widow is a "very clever woman" as, in keeping her own secrets, "she took full advantage of the general amnesty thus granted to all former faults and follies" (Ch. II). In terms of their past lies to one another they adopt the motto of "bygones are Bygones" (Ch. II).
} 
did intend to leave him behind, if necessary. This resolve demonstrates that her scheme is of greater importance to her than marital harmony.

As they prepare to return to England, the couple must determine how the Major can do so safely since he originally left under a cloud of suspicion. Previously, he never explained the reason for his emigration or why he cannot return under his own name, but now he falsely tells his wife that he killed his opponent in a romantic duel. As he tells this story, the Major covers his face with his hand in apparent agitation. At the same time, he peeps between his third and fourth finger at his wife to "see how she bore it" (Ch. III). She must check an inclination to smile because she is a "vast deal too clever to believe a single word of all he had said" (Ch. III). By pretending to believe him and thus, concealing her own cleverness the Widow practices her own deception and gains the upper hand over her husband.

Although he lies to her about his banishment from England, the Major respects her enough to ask her to "join her excellent judgement to mine" in working out the difficulties connected with his return (Ch. III). When he asks if she has an objection to his assuming the O'Donagough's name, she doesn't approach the suggestion sentimentally, but replies, "it would be foolish to take fancies when we are talking about business" (Ch. III). The couple acts as equal partners in this scheme and are "united by their plans and their enjoyment over them" (Ch. III). Their unity around this scheme brings new life to their marriage as they "never enjoyed each other's conversation more, since the first happy hour of confidence at Clifton" (Ch. III). This particular plan is the first, but certainly not the last, scheme in which the Major and 
the Widow act as near-equal partners. At this point, the Major highlights her skills by praising his wife, not for her wifely submissiveness to him, but for her intelligence and her valuable assistance to his plan,

My dear Barnaby, you are, without flattery, one of the sharpest-witted and most intelligent women I ever met with; it is only on points, where nothing but experience and a more extended knowledge of the world has assisted me, that I can assume any sort of superiority to you; and even here, you have only to open your own charming eyes a little, in order to...lessen the distance between us (Ch. III).

Although the Major praises her intelligence, he still claims superiority over her. As I argue below, however, his superiority is not sustained through the third novel.

Despite their apparent equality in planning the Major's new identity, the Major asserts dominance over his wife during their early days back in England. On their first day back, for example, the Widow argues with him quite forcibly over the late delivery of their luggage. She rebukes and scolds her husband but she knows that she must limit her "conjugal vivacities" because he will eventually settle the account with a "manly preponderance of force" (Ch. VIII). Although she possesses courage and confidence, she feels something close to awe for her husband, so she refrains from defying him in all their little disputes. Her restraint signals her status as the less powerful partner in their marriage. From the Major's point of view, he feels "the 
necessity of having his own way but achieved it with as little quarrelling as possible" (Ch. IX). He knows that "his Barnaby" was a high-spirited woman who does not live very easily under the matrimonial yoke, who prefers a "little skirmish" now and then, even though she knows that she must "yield eventually to the contemptible submissiveness of living as if she had no will of her own at all" (Ch. IX). Therefore, he lets her continue arguing as though she might win, but then utters his denial "only at the moment when he could walk off" (Ch. IX). Despite his praise of her intelligence, he still expects her obedience and eventual submission as his wife.

When the family moves from Brighton to London, the Major again exerts dominance over the Widow. He decides, without consulting her, they must live cheaply and in obscurity, away from fashionable society, for the first couple of months. Therefore, he moves the Widow and their daughter Patty to rather poor lodgings. Although she calls it the "very horridest den," the Widow complies with his wishes and tries to persuade Patty not to complain, saying there is no use contradicting the him (Ch. XIX). The Major, "a man of considerable firmness," refuses to explain his affairs saying, "girls or women can't possibly understand the subject because they are never brought up to it" (Ch. XIX). Further, he threatens to leave them behind if they complain or question him further. The Widow submits to his demands, claiming she has no power and must stay where her husband commands. This attitude is an extreme contrast with the Widow's earlier thoughts of leaving him in Australia to accomplish her own plans in England. In this section of the novel, the 
Widow, trusting in his ability to plan well, obeys her husband and behaves like a submissive wife. The Major holds the power in their marriage, at least for a time.

For the remainder of The Widow Married, the couple engages in two parallel schemes: the Widow wishes to orchestrate an advantageous marriage for Patty while the Major plans to trick a gullible heir out of his fortune through cheating at cards. Both plots depend on the couple's acceptance into fashionable society. The Major's scheme involves the Widow insofar as she acts as the hostess for social gatherings where he initiates high stakes play. Although the Widow knows about his card playing, he does not fully confide in her about his intentions; she assists him in his schemes, but her own cleverness is not engaged in this process as it was when they planned to have the Major assume the O'Donagough alias. The balance of power, however, shifts once again in the third novel, The Barnaby's in America.

This novel of the trilogy opens with the Major confessing to the Widow that he has been caught cheating at cards by General Hubert. Hubert, wanting to avoid embarrassment, urges the Major to leave England in order to escape prosecution. The Major considers lying to his wife just as he had lied about his original banishment from England. Instead, he decides to be truthful because he needs the advantage of the "very acute faculties of his wife" to figure out what to do next (Ch. IV). Further, he realizes her "strong practical sharpness" would likely detect his lies (Ch. IV). Rather than acting as a tyrant, as he did when they moved to London, the Major includes her in the decision making. Together, they decide to travel to New Orleans where they have heard there are many people of high fashion. They also decide to 
shed the name O'Donagough and assume the Barnaby name during their travels. The Major envisions new victims for his card games while the Widow declares herself ready to do battle with any new problems. In America, the Widow not only deals very well with difficulties, but she also takes the lead in imaginative money-making schemes.

In New Orleans, she reinvents herself as a famous author writing a book in praise of America ${ }^{43}$. She wins over the plantation owners by writing a chapter vigorously defending slavery. When the invitations flood in, the Widow calculates that their family can live expense-free for four or five months and that eventually she will earn a fortune from her book. In this plot, the Major acts as her assistant and obeys her instructions. She directs him, for example, in how to convince Mrs. Beauchamp, her wealthy American friend, that she is a highly successful author. When she receives accolades for her first chapter, the Major suggests they borrow money from the plantation owners. The Widow, in charge of this adventure, rejects his idea telling him to let her go her own way. She knows asking for money "will kill their passion for her" (XXVI). The Major acquiesces, allowing her to direct the scheme.

The Widow, riding high on her success, has a fascinating dream in which she envisions her superiority over her husband. In her sleep, she is in truth a famous author who tells the Major, "it is not you who have written all these books; and if, as you all justly enough say, a title must and will be given...it cannot be given to you...it

\footnotetext{
${ }^{43}$ As a British author writing about America, the widow Barnaby becomes an alter ego for Trollope who wrote an infamous book, Domestic Manners of the Americans, criticizing the American system and people.
} 
must and will be given to ME" (XXI). "You will never be Sir Anything" (XXI). She imagines herself a titled aristocrat while her husband remains a commoner. She asserts herself as the more powerful partner who is the complete opposite of a conventionally submissive and supportive Victorian wife. Although the Major is not aware of her fantasy, he does acknowledge and express his pride in her inventiveness. He envisions their visiting various country seats with her writing her immortal books and him raking in dollars every night while all the while their own money lies snug.

The Major, of course, still cheats at cards although he knows he should not win too much money lest their hosts suspect him. Unfortunately, one evening he drinks too much and is too successful at cards. He fears that his fellow players, once they recover from overindulging, will soon realize and accuse him of cheating. Interestingly, he goes to his wife for a solution. Although she is quite angry, not wanting to walk away from her own success as a celebrated author, she quickly and cleverly devises a scheme for their escape. She pretends to be deathly ill and in need of urgent medical attention in New York. The family, however, will actually proceed to Philadelphia; since there is no high play there, the Beauchamp family will not look for them there. The Major praises her superior inventive skills saying, "I can never hope to equal you in any thing" and declaring "you were born for me" (XXVIII). After their successful escape from New Orleans, the Widow continues to take the lead in profitable adventures. 
In Philadelphia, she once again pretends to be a successful author writing in praise of America. This time, in alignment with the Quakers' beliefs, she claims she will write a scathing denunciation of slavery. She swindles the Quakers out of $\$ 500$, ostensibly a travel fund allowing her to educate herself by visiting slave states. When the Quakers realize the Barnaby's true character, the family finds themselves, once again, in need of an escape plan. Just as in New Orleans, the Widow takes the lead in planning their escape and again proves herself the more cunning partner in her marriage.

In New York, their next stop, the Widow must continue to exert her cleverness in finding ways for the family to escape retribution for the Major's duplicity. After the Major swindles a fortune from a couple of New Yorkers, his bulging wallet attracts the notice of a curious and suspicious lawyer, Mr. Monkton. The Widow saves him from pursuit by helping him escape from a steamboat. Once again, she washes away her rouge and feigns illness; as she is escorted from the boat, the Major, dressed in her clothes, slips away unnoticed. When Monkton persists with his pursuit, the Widow persuades her husband to assume the persona of a minister by dressing in the Rev. O'Donagough's old suit. In this guise, the Major's acting skills allow him to escape all suspicion. The story of their American travels centers around the Widow's cleverness both in furtherance of her own schemes and in helping the Major escape from his mistakes.

The Barnabys in America is filled with praise for the Widow's inventiveness; this admiration emanates both from the Widow and from the Major. In her dream, as we 
have already seen, she imagines a title for herself based on her persona as a famous novelist. At the Beauchamp plantation, she refers to her genius in planning their escape. As she designs their escape from the steamboat, she asks the Major to give her "powers full scope" (Ch. XXXIX). She then reflects, "difficulties seem but to excite and expand my own powers, which I ever have done through every stage of my remarkable existence" (Ch. XXXIX). Her confidence in her intelligence and skillful deceptions is exactly the opposite of the nineteenth-century domestic ideal of a submissive wife meeting her husband's needs and following his lead.

The Major acknowledges her superiority as he praises her with increasing fervor throughout the novel. In New Orleans, after she is praised for her writing, the Major tells her how much he loves her and that he doesn't believe you've got "your equal in the old world or the new" (Ch. XXII). When he hears of her plans for a subscription from the Quakers in Philadelphia, his praise increases, he assures her of the "admiration I feel for the brilliant versatility of your talents...my happy destiny has mated me with a mind worthy of union with my own" (Ch. XXXII). After she suggests he impersonate a minister to escape his pursuers, the Major states, "you are a wonder of a woman and I believe you could make me do anything in the world that you took it into your head to command. You shall find me a perfect pattern of obedience" (Ch. XLI). The Major begins by praising her skills, proceeds to declaring her an equal to him, and ends by submitting his obedience. This progression ends with an inversion of normal gender roles in which the wife is normally obedient to her husband. 
The power balance in the Allen/Barnaby marriage shifts significantly from The Widow Married to The Barnaby's in America. The Widow appears to lose power in the first of these novels wherein she follows her husband obediently and reflects on her lack of choices. In the last novel, however, she begins as her husband's equal partner, a wife too clever to deceive. She moves on from that status to her role as the superior partner; the novel, in fact, revolves around her brilliance and her money-making schemes. The Major, as the more obedient partner, acts as the assistant to her schemes and then relies on her for help. Helen Heineman, in fact, is quite correct when she argues that the "superiority of women" was a constant theme of Trollope's appearing in many of her books (1979 167). The Widow Barnaby proves her superiority to other women and eventually to her own husband throughout the last novel.

The Widow Barnaby trilogy begins with an unconventional widow challenging social conventions to find a wealthy second husband. The first novel satirizes romantic marriage and the romance plot by uncovering the significance of money in marriage. Because of her transgressions, the Widow's character suggests a subversive alternative to the ideal nineteenth century woman. The second and third novels continue to satirize the domestic ideal of marriage by revealing the negotiations and power struggles in the Allen/Barnaby relationship. In the end, the Widow proves the more powerful spouse, thus inverting traditional gender roles in their marriage. Unlike the gender and class inversions in the novels I analyzed in Chapters Two and Three, this gender inversion does not appear to be temporary as in 
Pin Money or The Semi-Attached Couple. In fact, the trilogy ends with the Major continuing to acknowledge his wife's superior intelligence and talents. As I discussed in Chapter One, the temporary nature of inversions in Bakhtin's carnival renders them less subversive, less threatening to the status quo. The Widow's seemingly long-term position as the more intelligent and skillful partner in her marriage is therefore more threatening and subversive. She transgresses the traditional domestic ideal of the wife limited to the private sphere, as spiritual center of the home. To the contrary, she conducts her own business affairs in the public sphere by swindling the slave owners and the Quakers. In addition, she cleverly rescues her husband from his miscalculations in his own schemes. The ending of the trilogy suggests that this marital relationship - a mix of affection and business - will continue. The character of the unruly Widow Barnaby, therefore, is the most formidable challenge to nineteenth-century domestic ideology among the comic grotesque female characters I have studied. 


\section{CONCLUSION}

The novels covered in this study shed light on the subversive potential of the comic grotesque character in female-authored popular fiction of the mid-nineteenth century. Female authors deploy these humorous characters-the excessively overweight or talkative female--as more than figures of ridicule. They employ the comic grotesque character as a basis for critiquing the social and political norms. Corpulent characters challenge their middle-class status by achieving acceptance in, and enjoying the benefits of, upper-class society. Through the shift from middle to upper-class status, the reader as well as the characters of the novel are exposed to the artificiality of a rigid class structure and led to question its supposed naturalness. Similarly, female garrulous characters transgress normative gender hierarchies-the husband's authority over his wife-by exerting authority over their husbands and/or male relatives. Thus, they challenge assumptions surrounding male authority. The comic grotesque not only satirizes the romantic marriage ideal but also critiques the financial basis of and immorality surrounding aristocratic marriages. These criticisms of gender roles, class structure and marriage act subversively to challenge male authority.

Gender and class roles in early to mid-nineteenth century novels are especially relevant as they were changing during this period. In Family Fortunes, Leonore Davidoff and Catherine Hall theorize that gender roles, especially for the middle class, were in flux between 1780-1850. During this time period, a realigned gender order emerged as existing expectations about the proper roles of men and women 
were re-worked with a significantly different emphasis (xvi). Between 1780-1850, Davidoff and Hall claim that "family, home, masculinity and femininity were redrawn, negotiated, reformed and reinstalled" (xvi). The notion of separate spheres became more solidified during this period. This time period had significant implications for class affiliation as well as for gender roles. Members of the middle class, critical of many aspects of aristocratic privilege and power, sought to translate their increasing economic weight into a moral and cultural authority (30). The middle class strove to "exercise this moral authority not only within their own communities...but in relation to other classes" (30). These fluctuations in class and gender roles are especially important to my study as my chosen novels were written during the very same time frame.

By focusing on comic fiction by female authors, this study has addressed a gap in the critical work on female humor, especially by non-canonical authors, by identifying and analyzing their employment of satire to critique socio-cultural norms. Female comic authors during the mid-nineteenth century have received little attention from twentieth and twenty-first century literary critics. Book-length analyses of nineteenth-century humorous authors commonly begin with Jane Austen and then continue with an exclusively male list. Roger Henkle, for example, in Comedy and Culture studies British comedy from 1820 to 1900 and only mentions male authors. Regina Barrecca and Nancy Walker both observe the absence of female authors from studies of humor as well as from the canon. Although relatively scarce, a few humor critics have studied nineteenth-century women's humor. Barrecca's Untamed and 
Unabashed: Essays on Women and Humor in British Literature examines humor in novels by Austen and Charlotte Brontë. Audrey Bilger's study of late-eighteenth and early-nineteenth century novels, Laughing Feminism, analyzes subversive comedy in the works of Frances Burney, Maria Edgeworth and Jane Austen. Eileen Gillooly's Smile of Discontent theorizes feminine humor, a subtle satirical wit by female authors, in works by Austen, Elizabeth Gaskell and George Eliot. Although they make an important contribution to the critical work on humor, Barreca, Bilger and Gillooly focus only on canonical authors, especially on Austen.

The humor in early to mid-nineteenth century popular fiction has received relatively little attention. Although Frances Trollope's novels outsold those of both her son and of Charles Dickens during her lifetime, many of her novels are now out of print. Therefore, most critical work on Trollope has concentrated on her Domestic Manners travelogue and only a few of her novels ${ }^{44}$. Scholarship about Emily Eden's two novels most often explores the relationship of her novels to colonialism, based on her letters from India. Analyses of her humor focus on her novels' parallels to Austen's plots or characters. ${ }^{45}$ Similarly, scholars of Gore concentrate mainly on her development of the Silver Fork genre in the 1830's. This study has created new avenues for the exploration of satire in popular fiction of this period.

This dissertation has also addressed a gap in critical work on the nineteenthcentury comic grotesque character by focusing on its ability to invert gender and

\footnotetext{
${ }^{44}$ As my bibliography indicates, Helen Heineman, Carolyn Lambert and Brenda Ayres have accomplished the most fruitful work on the Widow Barnaby series.

${ }^{45}$ One exception is a dissertation by Susan Glass Fellows on humor in Victorian female authors. She analyzes Eden's The Semi-Attached Couple for its satire.
} 
class roles. In this way, these characters highlight the artificiality of these roles.

Critical works on the nineteenth-century grotesque, such as Wolfgang Kayser's study of literature of the Romantic period, mostly focus on the terror in the grotesque. Kayser, for example, emphasizes the role of the uncanny in grotesque phenomena and minimizes the comic elements present in the grotesque. The few studies of the comic grotesque in nineteenth-century novels concentrate entirely on texts by male writers. Charles Dickens, for example, has received the majority of critical attention for his comic grotesques.

Future research could further explore the subversiveness of the humor in noncanonical female authors of this period. Humor scholars might extend my analysis of the comic grotesque to examine the transgressiveness of these characters in other female-authored texts. They might also focus on the satire situated in other, nongrotesque, characters, comic situations and/or humorous language. An exploration of the works of other popular humorous authors with relatively little critical attention, such as Susan Ferrier, Maria Edgeworth, and Mary Russell Mitford, may prove fruitful. There is still much to learn about female humor in the nineteenth century. 


\section{BIBLIOGRAPHY}

\section{Primary Texts:}

Austen, Jane. Sense and Sensibility (1811), edited by Kathleen James-Cavan. Ontario: Broadview Literary Texts, 2001.

--. Persuasion (1815-6), edited by Linda Bree. Ontario: Broadview Literary Texts, 2004.

Eden, Emily. The Semi-Attached Couple (1839). New York: Virago Modern Classics, 1992.

--. The Semi-Detached House (1859). New York: Virago Modern Classics, 1992.

Gore, Catherine Grace Frances. Pin Money (1831). London: Geo. Routledge \& Co., 1854.

Trollope, Frances. The Barnabys in America or Adventures of the Widow Wedded (1843). Miami: Hardpress, 2017. Kindle file.

--. The Widow Barnaby (1839). London: Richard Bentley, 1839. Kindle file.

--. The Widow Married: A Sequel to the Widow Barnaby (1840). Miami: Hardpress, 2017. Kindle file.

\section{Secondary Texts:}

Alexander, Sarah C. "A Tale of Two Dandies: Gore, Dickens and the "Social-Fork" Novel." Women's Writing. vol. 16, no. 2, 2009, pp. 283-300.

Anderson, Bonnie. "The Writings of Catherine Gore." Journal of Popular Culture. vol. 10, no. 2, September 1976, pp. 404-423.

Arthurs, Jane. "Revolting Women: The Body in Comic Performance." Women's 
Bodies: Cultural Representations and Identity. Ed. Jane Arthurs and Jean

Grimshaw. New York: Continuum, 1999.

Ashley, Kathleen. Introduction. Victor Turner and the Construction of Cultural Criticism: Between Literature and Anthropology, edited by Kathleen Ashley. Indiana University Press, 1990, pp. ix-xxii.

Auerbach, Emily. Searching for Jane Austen. University of Wisconsin Press, 2004.

Ayers, Brenda. Dissenting Women in Dickens' Novels: The Subversion of Domestic Ideology. Westport, CT: Greenwood, 1998.

Babcock, Barbara A. "Introduction." The Reversible World: Symbolic Inversion in Art and Society, edited by Barbara Babcock. Cornell University Press, 1972, pp. 1-36. --. "Liberty's a Whore: Inversions, Marginalia and Picaresque Narrative." The Reversible World: Symbolic Inversion in Art and Society. Cornell University Press, 1972, pp. 95-116.

Bakhtin, Mikhail. The Dialogic Imagination. trans. Caryl Emerson and Michael Holquist. University of Texas Press, 1981.

--. (1965) Rabelais and His World. MIT Press, 1968.

Barasch, Frances. The Grotesque: A Study in Meanings. The Hague: Mouton, 1971. --. "Grotesque as Comic Genre." Modern Language Studies. vol. 15, no. 4, Winter 1985, pp. 3-11.

Barnard, Robert. “Frances Trollope (1779-1863): Life and Adventures of a Clever Woman." Brontë Studies, vol. 37, no. 2, April 2012, pp. 83-89.

Barreca, Regina. Last Laughs: Perspectives on Women and Comedy. Routledge, 1988. 
Bergson, Henri. "Laughter." Rpt. In Comedy. Garden City: Doubleday, 1956, pp. 61190.

Bilger, Audrey. Laughing Feminism: Subversive Comedy in Frances Burney, Maria Edgeworth and Jane Austen. Wayne State University Press, 1998.

Bilston, Sarah. "Your Vile Suburbs Can Offer Nothing but the Deadness of the Grave." Victorian Literature and Culture. vol. 41, 2013, pp. 621-642.

Bordo, Susan. Unbearable Weight, Feminism, Western Culture, and the Body. University of California Press, 1993.

Brown, Erica. Comedy and the Feminine Middlebrow Novel. London: Pickering \& Chatto Publishers, 2013.

Brown, Susan, Patricia Clements, and Isobel Grundy, eds. Catherine Gore entry: Overview Screen within Orlando: Women's Writing in the British Isles from the Beginnings to the Present. Cambridge: Cambridge University Press Online, 2006. <//orlando.cambridge.org/>. 13 July 2019.

Brumley, Anne. "As Horace Fat in a Slim Land: Ben Jonson's Experience and Strategy." Historicizing Fat in Anglo-American Culture, edited by Elena Levy-Navarro. Ohio University Press, 2010, pp. 111-128.

Bruns, John. Loopholes: Reading Comically. New Brunswick: Transaction Publishers, 2009.

Burke, Peter. Popular Culture in Early Modern Europe, London: Templesmith, 1978.

Butter, Stella. "The Grotesque as a Comic Strategy of Subversion. Mapping the Crisis of Masculinity in Patrick McGrath's The Grotesque." Orbis Litterarum. vol. 62, no. 
4, August 2007, pp. 336-352.

Camus, Marianne. The Female Grotesque in Dickens. The Grotesque in the Fiction of Charles Dickens and Other Nineteenth-century European Novelists. Edited by Isabelle Hervouet-Farrar and Max Vega-Ritter. Cambridge Scholars Publishing, 2014, pp. 192-202.

Castellanos, Gabriella. Laughter, War and Feminism: Elements of Carnival in Three of Jane Austen's Novels. New York: Peter Lang Publishing, 1994.

Chapone, Hester. Letters on the Improvement of the Mind: Addressed to a Lady. London: C. Whittingham, 1822.

Cixous, Hélène. "The Laugh of the Medusa." Signs. vol. 1, no. 4, 1976, pp. 875-893.

--. and Catherine Clément. The Newly Born Woman, translated by Betsy

Wing. University of Minnesota Press, 1986.

Clayborough, Arthur. The Grotesque in English Literature. Oxford: Clarendon Press, 1965.

Connelly, Frances. The Grotesque in Western Art and Culture. Cambridge University Press, 2012.

Cohen, Jeffrey Jerome. "Monster Culture (Seven Theses)." Monster Theory: Reading Culture, edited by Jeffrey Jerome Cohen. University of Minnesota Press, 1996, pp. $3-25$.

Cohen, Monica F. Professional Domesticity in the Victorian Novel: Women, Work and Home. Cambridge University Press, 1998.

Covino, Deborah Caslav. "Abject Criticism.” Genders. vol. 32, 2000. 
Craik, Katharine A. Introduction. An Essay on the Art of Ingeniously Tormenting. Oxford World's Classics, Oxford University Press. Kindle Edition.

Craton, Lillian. "The Widest Lap: Fatness, Fasting, and Nurturance in NineteenthCentury Fiction." Other Mothers: Beyond the Maternal Ideal, edited by Ellen Bayuk Rosenman and Claudia C. Klaver. Ohio State University Press, 2008, pp. 291-312.

--. Victorian Freak Show: The Significance of Disability and Physical Differences in Nineteenth-century Fiction. Amherst, NY: Cambria Press, 2009.

Cunningham, Gail. “Houses in Between: Navigating Suburbia in Late Victorian Writing." Victorian Literature and Culture. vol. 32, no. 2, 2004, pp. 421-434.

Davidoff, Leonore and Catherine Hall. Family Fortunes: Men and Women of the English Middle Class 1780-1850. New York: Routledge, 1988.

Davis, Natalie Zemon. Society and Culture in Early Modern France: Eight Essays by Natalie Zemon Davis. Stanford: Stanford University Press, 1975.

Ellis, Sarah. The Daughters of England: Their Position in Society, Character and Responsibilities. New York: D. Appleton \& Company, 1843.

Emerson, Caryl and Gary Morson. Bakhtin: Creation of a Prosaics. Stanford University Press, 1990.

Fellows, Susan. But is it Satire? Satire in the Novels of Victorian Women Writers. Dissertation. University of California, Riverside, 1995.

Fordyce, James. Sermons to Young Women. Vol. II. London: George Sidney, 1809. Foucault, Michel. Discipline and Punish. New York: Pantheon, 1977. Freud, Sigmund. Jokes and their Relation to the Unconscious (1905). Edited and 
translated by Lytton Strachey. W.W. Norton \& Co., 1989.

Fryett, Sarah E. Liminal Laughter: A Feminist Vision of the Body in Resistance.

Dissertation, Florida State University, 2011.

Gallagher, Catherine. "The Body versus the Social Body in the Works of Thomas Malthus and Henry Mayhew." The Making of the Modern Body: Sexuality and Society in the Nineteenth Century, edited by Catherine Gallagher and Thomas Laqueur. Berkeley: University of California Press, 1987, 83-106.

Garland-Thomson, Rosemarie. Extraordinary Bodies: Figuring Physical Disability in American Culture and Literature. Columbia University Press, 1997.

--. "Integrating Disability, Transforming Feminist Theory." NWSA Journal, vol. 14, no. 3, Feminist Disability Studies, Autumn 2002, pp., 1-32.

Gasbarrone, Lisa. “Locus for the Other: Cixous, Bakhtin and Women's Writing." $A$ Dialogue of Voices: Feminist Literary Theory and Bakhtin. edited by Karen Hohne and Helen Wussow. University of Minnesota Press, 1994, pp. 1-19.

Gilbert, Joanne. Performing Marginality: Humor, Gender, and Cultural Critique.

Detroit: Wayne State University Press, 2004.

Gillooly, Eileen. Smile of Discontent: Humor, Gender, and Nineteenth-Century British Fiction. University of Chicago Press, 1999.

Ginsburg, Ruth. The Pregnant Text. Bakhtin's Ur-Chronotope: The Womb. Bakhtin: Carnival and Other Subjects: Selected Papers from the Fifth International Bakhtin Conference. University of Manchester, July 1991, edited by David Shepherd. Atlanta, GA: Rodopi-Critical Studies vol. 3, no. 2 and vol. 4, no. 1 and 2, 1993, pp. 
165-176.

Gregory, John. A Father's Legacy to his Daughters (1774). Edinburgh: A. Strahan, 1788.

Gullage, Amy. "Fat Monica, Fat Suits, and Friends." Feminist Media Studies, vol. 14, no. 2, 2014, pp. 178-189.

Guarracino, Serena. "It's Not Over Till the Fat Lady Sings: The Weight of the Opera Diva." Historicizing Fat in Anglo-American Culture, edited by Elena Levy-Navarro. Ohio University Press, 2010, pp. 192-212.

Harpham, Geoffrey. "The Grotesque: First Principles" The Journal of Aesthetics and Art Criticism. vol. 34, no. 4, 1976, pp. 461-468.

--. On the Grotesque: Strategies of Contradiction in Art and Literature. Princeton University Press, 1982.

Hartley, Cecilia. "Letting Ourselves Go: Making Room for the Fat Body in Feminist Scholarship." Bodies Out of Bounds: Fatness and Transgression, edited by Jana Evans Braziel, and Kathleen LeBesco. Los Angeles: University of California Press, 2001, pp. 60-73.

Heath, Kay. "In the Eye of the Beholder: Victorian Age Construction and the Specular Self." Victorian Literature and Culture. vol. 34, no. 1, 2006, pp. 27-45.

--. “Marriageable at Midlife: The Remarrying Widows of Frances Trollope and Anthony Trollope." Frances Trollope and the Novel of Social Change. edited by Brenda Ayres. Greenwood Press, 2002, pp. 85-104.

Heineman, Helen. Frances Trollope. Boston: G.K. Hall \& Company, 1984. 
--. Mrs. Trollope: The Triumphant Feminine in the Nineteenth Century. Ohio University Press, 1979.

Henley, Nancy. Body Politics: Power, Sex and Non-verbal Communication. PrenticeHall, 1977.

Henning, Sylvie Debevec. "La Forme In-Formante": A Reconsideration of the Grotesque. Mosaic: An Interdisciplinary Critical Journal. vol. 14, no. 4, Fall 1981, pp. 107-121.

Hervouet-Farrar, Isabella. "Introduction." The Grotesque in The Fiction of Charles Dickens and Other Nineteenth-century European Novelists, edited by Isabella Hervouet-Farrar \& Max Vega-Ritter, 2015.

Hole, Anne. "Performing Identity: Dawn French and the Funny Fat Female Body." Feminist Media Studies. vol. 3, no. 3, 2003, pp. 315-328.

Hollington, Michael. Dickens and the Grotesque. London: Croom Helm, 1984. Holmes, Janet. "Language Prejudice: Language Myth \#6: Women Talk Too Much.” From the PBS series: Do You Speak American? 2005.

Huff, Joyce. Conspicuous Consumptions: Representations of Corpulence in the Nineteenth-Century British Novel. Dissertation. George Washington University, 2001.

-. “Fosco's Fat Drag: Performing the Victorian Fat Man in Wilkie Collins's The Woman in White." Historicizing Fat in Anglo-American Culture, edited by Elena Levy-Navarro. Ohio University Press, 2010.

—. "A "Horror of Corpulence": Interrogating Bantingism and Mid-Nineteenth-Century 
Fat-Phobia." Bodies Out of Bounds: Fatness and Transgression, edited by Jana

Evans Braziel and Kathleen LeBesco. University of California Press, 2001. 39-59. Hume, Kathryn. "Conjugations of the Grotesque." Aggressive Fictions. Cornell University Press, 2011, pp. 77-114.

Jacobus, Mary, Evelyn Fox Keller, and Sally Shuttleworth. Introduction. Body/Politics:

Women and the Discourses of Science. New York: Routledge, 1990, pp. 1-10.

Jalland, Pat. Death in the Victorian Family. Oxford University Press, 1996.

Kayser, Wolfgang. The Grotesque in Art and Literature. translated by Ulrich Weisstein.

Bloomington: Indiana University Press, 1957.

Keith-Speigel, Patricia. "Early Conceptions of Humor: Varieties and Issues." The Psychology of Humor: Theoretical Perspectives and Empirical Issues, edited by J.H. Goldstein and P.E. McGhee. New York: Academic Press, 1972.

Kendra, April Nixon. "'You, Madam, Are No Jane Austen': Mrs. Gore and the Anxiety of Influence." Nineteenth-Century Gender Studies. vol. 3, no. 2, Summer 2007, pp. 1-8.

Klein, Richard. "Fat Beauty." Bodies Out of Bounds: Fatness and Transgression, edited by Jana Evans Braziel and Kathleen LeBesco. University of California Press, 2001. 19-38.

Kling, Rebecca. "'It is only colour that you want': Lady Audley's Secret and Cosmetics as Discursive Fantasy." Victorian Periodicals Review. vol. 50, no. 3, Fall 2017, pp. 560-584.

Kramer, Chris. Excessive Loquacity: Women's Speech as Represented in American 
Etiquette Books, Jul 1975, pp. 1-25.; Paper presented at the Annual Meeting of the Speech Communication Assn., Austin, Texas, July 10-12, 1975.

Kyrola, Katariina, and Hannele Harjunen. "Phantom/Liminal Fat and Feminist Theories of the Body." Feminist Theory, 2017, vol. 18, no. 2 pp. 99-117.

LaCapra, Dominick. "Bakhtin, Marxism and the Carnivalesque." Rethinking Intellectual History: Texts, Contexts, Language. Cornell University Press, 1983.

Lambert, Carolyn. "Frances Trollope and the Picaresque Marriage." Marriage in Novels by Women, edited by Carolyn Lambert and Marion Shaw. New York: Routledge, 2018, pp. 18-33.

--. Frances Trollope on Widows and Wedlock. Women: A Cultural Review, vol. 23, no. 3, 2012, pp. 373-375.

LeBesco, Kathleen. “Queering Fat Bodies/Politics.” Bodies Out of Bounds: Fatness and Transgression, edited by Jana Evans Braziel and Kathleen LeBesco. Berkeley: University of California Press, 2001. 74-97.

LeBesco, Kathleen, and Jana Evans Braziel. "Introduction." Bodies Out of Bounds:

Fatness and Transgression, edited by Jana Evans Braziel and Kathleen LeBesco. Berkeley: University of California Press, 2001, pp. 1-15.

Levy-Navarro, Elena. "Introduction: Changing Conceptions of the Fat Body in Western History." Historicizing Fat in Anglo-American Culture, edited by Elena LevyNavarro. Ohio University Press, 2010, pp. 1-16.

Linton, Eliza Lee. "The Girl of the Period." The Rebel of the Family. Broadview Press, 2002, pp. 412-417. 
Malone, Cynthia. "Near Confinement: Pregnant Women in the Nineteenth-Century British Novel." Dickens Studies Annual, vol. 29, Spring 2000.

McElroy, Bernard. Fiction of the Modern Grotesque. St. Martin's Press, 1989.

Michie, Helena. The Flesh Made Word: Female Figures and Women's Bodies. New York: Oxford University Press, 1987.

--. "Under Victorian Skins: The Bodies Beneath." A Companion to Victorian Literature \& Culture. edited by Herbert Tucker. Oxford: Blackwell, 1991, pp. 407-424.

Miles, Margaret. "Carnal Abominations: The Female Body as Grotesque." The Grotesque in Art and Literature: Theological Reflections, edited by James Luther Adams and Wilson Yates. Grand Rapids: William B. Eerdmans Publishing Company, 1997. pp. 83-112.

Miller, Elizabeth Carolyn. "'Shrewd Women of Business': Madame Rachel, Victorian Consumerism and L.T. Meade's 'The Sorceress of the Strand'". Victorian Literature and Culture. vol. 34, no. 1, 2006, pp. 311-332.

Morreall, John. Comic Relief: A Comprehensive Philosophy of Humor. J. Wiley and Sons, 2011.

Murray, Samantha. "Editor's Introduction: Rethinking Fatness -A Critical Dialogue." Feminism \& Psychology, vol. 22, no. 3, 2012 pp. 287-289.

--. "Normative Imperatives vs. Pathological Bodies." Australian Feminist Studies. vol. 23, no. 56,2008 , pp. $213-224$.

--. "(Un/Be)Coming Out? Rethinking Fat Politics." Social Semiotics. vol. 15, no. 2, 2005, pp. 153-63. 
O'Cinneide, Muireann. "The Victorian Suburb as Imperial State: Emily Eden and the Theatrics of Empire." Journeys, vol. 7, no. 1, 2006, pp. 51-65.

Parker, Patricia. Literary Fat Ladies: Rhetoric, Gender, Property. London: Methuen, 1987.

Petersen, Anne Helen. Too Fat, Too Slutty, Too Loud: The Rise and Reign of the Unruly Woman. New York: Plume, 2017.

Pinson, Patricia. The Shattered Frame: A Study of the Grotesque in Nineteenthcentury Literature and Music. 1971. Ohio University, Ph.D dissertation.

Plotz, Judith. “Jane Austen Goes to India: Emily Eden's Semi-Detached Home Thoughts From Abroad." The Postcolonial Jane Austen, edited by You-me Park and Rajeswari Sunder Rajan. Routledge, 2000, pp. 163-188.

Ravenscroft, Neil and Paul Gilchrist. "The Spaces of Transgression: Governance, Discipline and Reworking Carnivalesque." Leisure Studies. vol. 28, no. 1, January 2009, pp. 35-49.

Rogers, Pat. "Fat is a Fictional Issue: The Novel and the Rise of Weight-Watching." Historicizing Fat in Anglo-American Culture, edited by Elena Levy-Navarro. Ohio University Press, 2010, pp. 19-39.

Rowe, Kathleen. "Roseanne: Unruly Woman as Domestic Goddess." Screen, vol. 31, 1990, pp. 81-86.

--. The Unruly Woman: Gender and the Genres of Laughter. University of Texas, 1995.

Ruskin, John. "Grotesque Renaissance" in The Stones of Venice, vol 3. J. Wiley and 
Sons, 1860.

Russo, Mary. The Female Grotesque: Risk, Excess and Modernity. New York: Routledge, 1994.

--. "Female Grotesques: Carnival and Theory." Feminist Studies/Critical Studies, edited by Teresa de Lauretis. MacMillan Press, 1986, pp. 213-229.

Ruthke, Karl. Modern Tragicomedy: An Investigation into the Nature of the Genre. Random House, 1966.

Sedgwick, Eve Kosofsky and Michael Moon. “Divinity: A Dossier, A Performance Piece, a Little-Understood Emotion." Bodies Out of Bounds: Fatness and Transgression, edited by Jana Evans Braziel, and Kathleen LeBesco. Los Angeles: University of California Press, 2001, pp. 292-328.

Shaftesbury, Anthony Ashley Cooper. Sensus Communis: An Essay on the Freedom of Wit and Humour. New York: Garland Publishing, 1971.

Shepherd, David. Introduction: (Mis)Representing Bakhtin. Bakhtin: Carnival and Other Subjects: Selected Papers from the Fifth International Bakhtin Conference. University of Manchester, July 1991. Edited by David Shepherd. Atlanta, GA: Rodopi-Critical Studies vol. 3, no. 2 and vol. 4, no. 1 and 2, 1993, pp. xiii-xxxii. Shieff, Sarah. "Devouring Women: Corporeality and Autonomy in Fiction by Women Since the 1960s." Bodies Out of Bounds: Fatness and Transgression, edited by Jana Evans Braziel and Kathleen LeBesco. Berkeley: University of California Press, 2001, pp. 214-230.

Singleton, Pamela-Neville. "The Life and Adventures of a Clever Women." Frances 
Trollope and the Novel of Social Change, edited by Brenda Ayres. Greenwood Press, 2002, pp. 11-26.

Singley, Paulette. “Devouring Architecture: Ruskin's Insatiable Grotesque." Assemblage vol. 32, pp. 108-25. The MIT Press, 1997.

Smedley, Christine E. "Laughing in a Stone Ear" Transcending Binary Constructions of Identity Through Laughter. 2000. California State University San Marcos. Master's Thesis.

Spender, Dale. Man Made Language, $2^{\text {nd }}$ ed. London: Pandora, 1990.

Squire, Michael. "Fantasies so Varied and Bizarre": The Domus Aurea, the Renaissance and the "Grotesque." A Companion to the Neronian Age. London: Blackwell, 2013.

Staels, Hilde. "The Gothic and Grotesque in Barbara Gowdy's Mister Sandman." Studies in Canadian Literature. vol. 37, no. 2, 2012, pp. 172-191.

Stallybrass, Peter and Allon White. The Politics and Poetics of Transgression. Cornell University Press, 1986.

Steig, Michael. "Defining the Grotesque: An Attempt at Synthesis." Journal of Aesthetics and Art Criticism. vol. 29, no. 2, Winter 1970, pp. 253-260.

Stott, Andrew. Comedy. New York: Routledge, 2005.

Stukator, Angela. "Comedy, Carnivalesque and Body Politics." Bodies Out of Bounds: Fatness and Transgression, edited by Jana Evans Braziel and Kathleen LeBesco. Berkeley: University of California Press, 2001, pp. 197-214.

Sutphin, Christine. "Very Nearly Smiling: Comedy and Slave Revolt in The Barnabys in 
America. Women's Writing. vol. 18, no. 2, 2011, pp. 214-232.

Tannen, Deborah. You Just Don't Understand: Women and Men in Conversation, William \& Morrow Co., Inc., 1990.

Tave, Stuart M. The Amiable Humorist: A Study in the Comic Theory and Criticism of the Eighteenth and Early Nineteenth Centuries. The University of Chicago Press, 1960.

Taylor, Ben. Bakhtin, Carnival and Comic Theory. 1995. University of Nottingham, PhD dissertation.

Thomassen, Bjorn. "The Uses and Meanings of Liminality." International Political Anthropology. vol. 2, 2009, pp. 5-27.

Thomson, Philip. The Grotesque. London: Methuen \& Co., Ltd, 1972.

Turner, Victor. "Comments and Conclusions." The Reversible World: Symbolic Inversion in Art and Society, edited by Barbara Babcock. Cornell University Press, 1972, pp. 276-296.

--. "Frame, Flow and Reflection: Ritual and Drama as Public Liminality." Japanese Journal of Religious Studies. vol. 6, no. 4, Dec. 1979, pp. 465-499.

--. "Liminal to Liminoid, in Play, Flow and Ritual: an Essay in Comparative Symbology." Rice University Studies, vol. 60, no. 3, 1974, pp. 53-92

--. "Liminality and Communitas." The Ritual Process: Structure and Anti-Structure. Chicago: Aldine Publishing, 1969, pp. 94-130.

Valverde, Mariana. "The Love of Finery: Fashion and the Fallen Women in Nineteenth-Century Social Discourse." Victorian Studies: A Journal of the 
Humanities, Arts and Sciences. vol. 32, no. 2, 1989, pp. 169-188.

Vicinus, Martha. Introduction. Suffer and Be Still: Women in the Victorian Age. Edited by Martha Vicinus. New York: Routledge, 2013, pp. vii-xv.

Wagner, Tamara. Beyond Domestic Manners: Repositioning Frances Trollope in Literary History. Women's Writing, vol. 18, no. 2, 2011, pp. 153-166.

--. "From Satirized Silver Cutlery to the Allure of the Anti-Domestic in NineteenthCentury Women's Writing: Silver-Fork Fiction and Literary Legacies." Women's Writing. vol. 16, no. 2, 2009, pp. 181-190.

--. "A Strange case of the Olden Time: Revisions of the Regency in the Construction of Victorian Domestic Fiction." Modern Language Quarterly. vol. 66, no. 4, December 2005, pp. 443-75.

Walker, Nancy. A Very Serious Thing. University of Minnesota Press, 1988.

Williams, Neville. Powder and Paint: A History of the Englishwoman's Toilet Elizabeth I - Elizabeth II. London: Longmans, Green and Co, 1957.

Wilson, Cheryl A. "Almacks and the Silver-Fork Novel." Women's Writing. vol. 16, no. 2, 2009, pp. 237-252.

Wright, Thomas. A History of Caricature and Grotesque in Literature and Art (1865). New York: Frederick Ungar Publishing Co., 1968.

Yates, Wilson. "An Introduction to the Grotesque: Theoretical and Theological Considerations." The Grotesque in Art and Literature: Theological Reflections, edited by James Luther Adams and Wilson Yates. Grand Rapids: William B. Eerdmans, 1997, pp 1-68. 